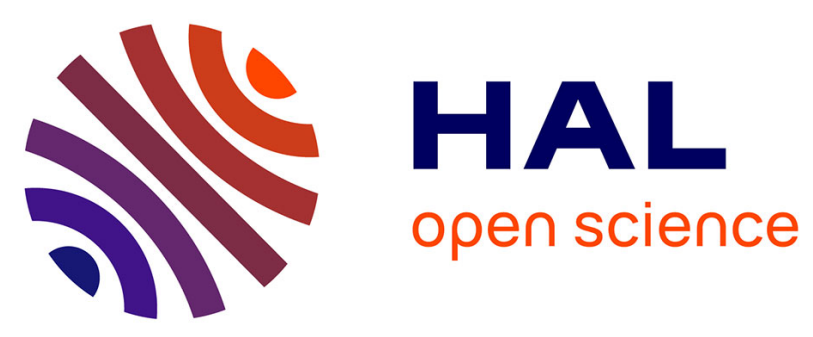

\title{
Transport of Volatile-rich Melt from the Mantle Transition Zone via Compaction Pockets: Implications for Mantle Metasomatism and the Origin of Alkaline Lavas in the Turkish-Iranian Plateau
}

A Soltanmohammadi, M. Gregoire, M. Rabinowicz, Muriel Gerbault, G.

Ceuleneer, M. Rahgoshay, M. Bystricky, M. Benoit

\section{To cite this version:}

A Soltanmohammadi, M. Gregoire, M. Rabinowicz, Muriel Gerbault, G. Ceuleneer, et al.. Transport of Volatile-rich Melt from the Mantle Transition Zone via Compaction Pockets: Implications for Mantle Metasomatism and the Origin of Alkaline Lavas in the Turkish-Iranian Plateau. Journal of Petrology, 2018, 59 (12), pp.2273-2310. 10.1093/petrology/egy097 . hal-01979646

\section{HAL Id: hal-01979646 https://hal.science/hal-01979646}

Submitted on 13 Jan 2019

HAL is a multi-disciplinary open access archive for the deposit and dissemination of scientific research documents, whether they are published or not. The documents may come from teaching and research institutions in France or abroad, or from public or private research centers.
L'archive ouverte pluridisciplinaire HAL, est destinée au dépôt et à la diffusion de documents scientifiques de niveau recherche, publiés ou non, émanant des établissements d'enseignement et de recherche français ou étrangers, des laboratoires publics ou privés. 
See discussions, stats, and author profiles for this publication at: https://www.researchgate.net/publication/328631536

\section{Transport of Volatile-rich Melt from the Mantle Transition Zone via Compaction Pockets: Implications for Mantle Metasomatism and the Origin of Alkaline Lavas in the Turkish-Iranian...}

Article in Journal of Petrology · October 2018

DOI: $10.1093 /$ petrology/egy097/5146822

CITATIONS

0

8 authors, including:

Michel Grégoire

French National Centre for Scientific Research

204 PUBLICATIONS 2,815 CITATIONS

SEE PROFILE
READS

3

Some of the authors of this publication are also working on these related projects:

Earth's lithospheric mantle beneath Europe (Polish National Centre of Scientific Research grant no 2014/15/B/ST10/00095) View project

Lithospheric mantle beneath northern Europe: comparison of Earth's lithospheric mantle rocks from selected areas affected by Caledonian orogeny to mantle rocks underlying the North Atlantic Craton and East European Craton (UMO-2016/23/B/ST10/01905) View project 


\title{
Transport of Volatile-rich Melt from the Mantle Transition Zone via Compaction Pockets: Implications for Mantle Metasomatism and the Origin of Alkaline Lavas in the Turkish-Iranian Plateau
}

\author{
A. Soltanmohammadi ${ }^{*}$, M. Grégoire ${ }^{1}$, M. Rabinowicz ${ }^{1}$, M. Gerbault ${ }^{1}$, G. \\ Ceuleneer ${ }^{1}$, M. Rahgoshay ${ }^{2}$, M. Bystricky³, M. Benoit ${ }^{1}$
}

${ }^{1}$ Geosciences Environnement Toulouse - Observatoire Midi-Pyrenees 14 A. E. Belin, Toulouse 31400, France

${ }^{2}$ Shahid Beheshti University, Faculty of Earth Sciences, Tehran, Iran

3 The Research Institute in Astrophysics and Planetology (IRAP), Observatoire Midi-Pyrenees, Toulouse, France

*Corresponding Author: e-mail : azamsoltanmohammadi@gmail.com

\begin{abstract}
This study is based on an integrated approach combining results from petrology, geophysics and modeling to explain the origin of continental alkaline magmatism in the Turkish-Iranian plateau (TIP). Synthesis of the petrological and chemical characteristics of the alkaline magmatism of the TIP, extending from $80 \mathrm{Ma}$ to the present, shows that the alkaline lavas can be classified as ultrapotassic (UK), transitional potassic to sodic (TK) and sodic-high potassium (HK) and sodiclow potassium (LK) lavas, all derived from a heterogeneous mantle source. Synthesis of the most recent seismic tomography images for the region shows the presence of a large set of low velocity elliptical bodies, $\sim 100 \mathrm{~km}$ in size, referred to as "Compaction Pockets" (CP), scattered from the top of the mantle Transition Zone (MTZ) to the base of the lithosphere beneath the TIP.
\end{abstract}

(C) The Author(s) 2018. Published by Oxford University Press. All rights reserved. For Permissions, please e-mail: journals.permissions@oup.com 
A model is developed which shows that the low velocities in these Compaction Pockets results from the percolation and concentration of volatile-rich melts liberated from the MTZ. These volatile-rich melts interact with their surrounding mantle that has a temperature $\sim 100{ }^{\circ} \mathrm{C}$ lower than the usual sub-continental mantle adiabat. It is argued that this results in the precipitation of hydrated and carbonated mineral phases (at $\sim 8-6.5 \mathrm{GPa}$ and $<4 \mathrm{GPa}$, respectively), and partial melting of the resulting heterogeneous mantle (6.5- $4 \mathrm{GPa})$ at critical depths. Melt extraction via dykes occurs when the top of the compaction pocket successively crosses these critical depths. The three groups of UK, sodic-LK and sodic-HK lavas may be linked to distinct melt extraction events. The chemical composition of TK melts may result from the mixing of UK and sodic melts, or partial melting of metasomatized mantle at lithospheric depths. The "Compaction Pocket" model offers a robust new concept to explain alkaline magmatism in the context of continental orogeny.

KEY WORDS: Compaction Pocket, volatile-rich melt, alkaline lava, mantle Transition Zone, orogenic belt

\section{INTRODUCTION}

Alkaline igneous rocks are derived from silica-undersaturated and alkali-rich parental magmas (Yoder \& Tilley, 1962). Most of them, if not all, have a mantle origin and fluids are clearly involved in their petrogenesis (e.g. Watkinson \& Wyllie, 1971). They occur in a variety of tectonic settings including oceanic and continental hotspots, continental shields and, to a lesser extent, in orogenic belts (Morgan, 1971; Streckeisen, 1979; Foley et al., 1987; Fitton \& Upton, 1987; Wilson, 1989; Rock, 1991; Mitchell \& Bergman, 1991). In orogenic belts, there is typically 
a wide range of compositions of alkaline rock from potassic to sodic. Geochemical data and experimental petrology support the view that their parental melts derive from an uncommon, heterogeneous mantle source. Accordingly, several scenarios have been proposed to explain the origin and diversity of alkaline magmas, including: (i) partial melting of metasomatized mantle along a slab-mantle wedge interface (Foley, 1994; O' Brein et al., 1995; Ulmer, 2001; Tumiati et al., 2013); ii) upwelling and underplating of enriched hot mantle beneath the lithosphere (Hole et al., 1991; Özdemir \& Gülec 2014; Prelević et al., 2014); iii) re-melting of previously underplated magmas or metasomatized lithosphere (Bonin et al., 1998; Avanzinelli et al., 2009); (iv) a combination of these scenarios (e.g. Prelević et al., 2008, 2010). A hot asthenospheric upwelling is often invoked to explain highly sodic characteristics and Ocean Island Basalt (OIB)-like trace element patterns, enriched in high field strength elements (HFSE; Nb, Ta, Ti). In contrast, the origin of potassium-rich alkaline magmas is more controversial. Petrological and experimental studies show that a potassium-rich melt could result from the modification of the mantle during processes removing or adding chemical components: for example, the addition of subducted sediments or K- rich mineral phases (e.g. phlogopite) at shallow depths (less than $150 \mathrm{~km}$ ) (Hawkesworth et al., 1993; Conceicao \& Green, 2004; Fumagali \& Poli, 2008; Tumiati et al., 2013; Condamine \& Medard, 2014; Forster et al., 2016; Condamine et al., 2016). Moreover, it is well documented that subduction zone processes add significant amounts of alkali elements $(\mathrm{K}$, $\mathrm{Rb}, \mathrm{Ba}$ ), $\mathrm{CO}_{2}$ and $\mathrm{H}_{2} \mathrm{O}$ to the MTZ (Angel et al., 2001; Rupke et al., 2004; Rapp et al., 2008; Grassi et al., 2012; Burnham et al., 2015; Thomson et al., 2016; Palot et al., 2017). Experimental studies also show that at equivalent depths to the MTZ, melts have a composition extremely rich in potassium and volatiles (Ulmer \& Sweeney, 2002; Rapp et al., 2008; Grassi et al., 2012, Litasov et al., 2013; Kuritani et al., 2013; Novella \& Frost, 2014). 
Outcrops of alkaline lavas are widespread within the Mediterranean and surrounding regions (Wilson \& Bianchini, 1999; Lustrino \& Wilson, 2007; Lustrino et al., 2011). The Turkish-Iranian Plateau (TIP) occupies a significant median portion of the Alpine-Himalayan orogenic belt. It is an ideal place to study the genesis of alkaline magmatism in an orogenic belt context because the history of the Tethys subduction beneath this region is relatively well constrained. In this study, we make a synthesis of the petrological and chemical characteristics of the alkaline magmatic activity of the TIP extending from 80 Ma to the present, based on data from about three hundred previous publications. As the petrographic classification schemes are quite variable from one publication to another, we considered only published geochemical analyses and geochronological data, when available, to build a self-consistent data base. This synthesis allows us to highlight, based on objective criteria, the large variety of potassic and sodic alkaline magmatic affinities in the TIP, together with their geographical distribution and chronology of emplacement.

The mantle sources of potassic and sodic lavas are usually explained by the classical scenario proposed for orogenic belts, i.e. melting of metasomatized lithosphere for the former, together with hot asthenospheric upwelling for the latter. However, among the potassium-rich rocks of the TIP, some lavas (e.g., lamproites) are characterized by high Mg-numbers and low silica contents as well as extremely high contents of large ion lithophile elements (LILE; e.g. K, $\mathrm{Rb}, \mathrm{Th}, \mathrm{U}$ ) and low contents of HFSE (e.g. Nb, Ta, Ti). Until now, rocks with these characteristics have never been robustly linked to mantle sources located at shallow depths. Here, we propose a physical model for the formation of such alkaline lavas that involves deep, potassic mantle sources. The model is based on petrological and geophysical data for the region and on the long history of the Tethys subduction ( $\sim 300 \mathrm{Myr})$, which likely led to the accumulation and 
density stratification of stacked stagnant slabs in the MTZ. We start by summarising the general geology and magmatism of the TIP. We then review existing geophysical and GPS data and interpret the presence of low velocity anomalies in the upper mantle as CP linked to the presence of volatile-rich melts or hydrous mineral phases. A model is then proposed for the generation of compaction waves from mantle melts originating at the top of the MTZ and for the development and migration of CPs. Finally, we discuss the link between these CPs and the observed distribution and chemical composition of the alkaline volcanism $(<\sim 11 \mathrm{Ma})$; we show that large CPs may also explain the distribution and chemical composition of older magmatism (80-10 Ma) throughout the TIP.

\section{GENERAL GEOLOGY OF TURKISH-IRANIAN PLATEAU (TIP)}

The TIP is one of the main plateaus in the Alpine-Himalayan orogenic belt. To the north the TIP is separated from the Scythian Platform by the Greater Caucasus Suture; to the south, it is separated from Arabia by the Bitlis-Zagros Suture (Fig. 1). The Plateau consists of several preMesozoic terranes (interpreted as "micro continents"), which accreted at different times. The opening and closing of several branches of the Tethys Ocean led to the amalgamation of various microcontinents and eventually to the formation of the TIP. Subduction of the Paleo-Tethys was mainly active along the Greater Caucasus from 360 to $210 \mathrm{Ma}$ (Stampfli et al., 2002). From 200 to $80 \mathrm{Ma}$, subduction of the Neo-Tethys developed along the Sakarya terrane, the SomkhetoKarabagh mountain belt and the Sanandaj-Sirjan zone (SSZ) parallel to the Izmir-AnkaraErzincan (IAE), the Lesser Caucasus and the Zagros Sutures, respectively (Adamia et al., 1977, 2011; Şengör \& Yilmaz, 1981; Yilmaz et al., 2000; Hassanzadeh \& Wernicke, 2016). Some authors argue that Neo-Tethys subduction was active even later, from the Late Cretaceous into 
the Cenozoic, beneath the Sakarya terrane (Pontides), the Armenia block and the Iranian plateau, along the IAE, the Lesser Caucasus and the Zagros Suture (Berberian \& King, 1981; Alavi, 1994; Agard et al., 2005, 2011; Ghasemi \& Talbot, 2006). A consensus has progressively emerged that the collision between Arabia and the Iranian Plateau occurred from $\sim 30 \mathrm{Ma}$ to $\sim 10 \mathrm{Ma}$ (McQuarrie et al., 2003; Francois et al., 2014) and that this led to a decrease in convergence rate by $30 \%$ from $13 \mathrm{Ma}$ to $5 \mathrm{Ma}$ (Austerman \& Iaffaldano, 2013). However, along the central and southeastern part of the Zagros Suture, plate boundary processes (e.g., delamination, slab breakoff or subduction) appear to be still active (Agard et al., 2011; Mohammadi et al., 2013; François et al., 2014). To the east, in the Bitlis region, such processes are also active, but the most likely process is the delamination of the Arabian plate (e.g. Göğüş et al., 2011). Parallel to the Lesser Caucasus, a linear zone of recent magmatism has ben interpreted in terms of delamination of the underlying continental lithosphere (e.g. Neill et al., 2015).

The TIP is characterised by widespread (up to $500 \mathrm{~km}$ in extent) and long-standing (200 Ma to present) magmatism, classically divided into four magmatic periods. Period 1 (Jurassic to Cretaceous) is characterized by abundant calc-alkaline plutonic rocks (Khalaj et al., 2007; Hassanzadeh \& Wernicke, 2016) and Period 2 (Late Cretaceous to Palaeocene) by widespread tholeiitic volcanism (e.g. Khalatbari, Jafari et al., 2016), intra-continental intrusions (i.e., A type granitoids, Boztug et al., 2007, Karsli et al., 2012a) and alkaline volcanism (Aghazadeh et al., 2015; Doroozi et al., 2015). Period 3 (Early to Middle Cenozoic), widely referred to as a magmatic "flare up", consists of widespread high K calc-alkaline to transitional alkaline lavas and related subvolcanic intrusions (Vincent et al., 2005; Boztug \& Jonckheere, 2007; Ardjmanzadeh et al., 2011; Verdel et al., 2011; Asiabanha \& Foden, 2012; Karsli et al., 2012b; Pang et al., 2013a; Moritz et al., 2016; Beydokhti et al., 2015; Ahmadian, et al., 2016; Deevsalar et al., 2017). Period 4, active since the Late Cenozoic, is characterized by alkaline lavas (Pearce 
et al., 1990; Wilson, et al., 1997; Aydin et al., 2008; Liotard et al., 2008; Lustrino et al., 2010; Mirnejad et al., 2010; Saadat et al., 2010; Saadat \& Stern, 2012; Allen et al., 2013; Pang et al., 2013b; Shafaii Moghadam et al., 2014; Aghazadeh et al., 2015; Kheirkhah et al., 2015; Prelević et al., 2014). During the Late Cretaceous-Early Cenozoic up to the present (periods 2, 3 and 4)

alkaline magmatism was extremely voluminous. From west to east, the main magmatic zones are: Central Anatolia, East Pontides-East Anatolia, Lesser Caucasus-NW Iran, Alborz, Central-East Iranian microcontinent and the linear magmatic belt of Urumieh- Dokhtar parallel to the Zagros Suture (Fig. 1). In the following, we describe the characteristics of these main magmatic zones.

\section{EXPOSED MAGMATISM IN THE TIP}

\section{Central Anatolia}

Central Anatolia lies within the Anatolid-Tauride block, limited by the Pontides to the north, and to the south by the Hellenic trench and the Bitlis-Zagros Suture (Fig. 1). Late CretaceousOligocene A and I-type granitoids occur at several sites. They are interpreted as resulting from Late Cretaceous, early to middle Paleocene (57-60 Ma) and Oligocene (28-30 Ma) rapid exhumation processes (periods 2 and 3) (Bozturge et al., 2007; Boztug \& Jonckheere, 2007). According to these studies, exhumation results from a regional compressional regime due to Arabia-Eurasia collision, affecting the area located between the Greater Caucasus and the BitlisZagros Sutures. Magmatism younger than Oligo-Miocene (period 4) occurs in three main zones: the Galatia volcanic Province (GVP), the Kırka-Afyon-Isparta (KAI) magmatic line and the Central Anatolia Province (CAP) (Fig. 1). The magmatism in the GVP is located along the North Anatolia fault and mainly consists of alkaline lavas (Wilson et al., 1997). Along the KAI, lavas have a strong alkaline affinity and are ultrapotassic (e.g., Prelević et al., 2014). The CAP covers 
an area of $300 \times 20-25 \mathrm{~km}$ and its magmatism is characterized by mostly mafic to intermediate calc-alkaline to alkaline lavas (i.e. Hasandagh and Erciyes volcanoes) (Temel et al., 1998; Aydin et al., 2014; Köprübasi, et al., 2014) with only few tholeiitic lava outcrops around the Hasandagh volcano (Köprübasi et al., 2014). However, there are no systematic relationships between magmatic composition and time. As an example, the magmatic affinities of the Hasandagh lavas shifted from older alkaline to younger calc-alkaline, whereas a reverse trend is observed for the alkaline to calc-alkaline lavas from the Erciyes volcano (e.g. Köprübasi et al., 2014). These observations have been linked to mixing between asthenospheric mantle and continental crustal sources (Aydin et al., 2014; Köprübasi et al., 2014).

\section{Eastern Pontides to Eastern Anatolia}

\section{East Pontides}

The Pontides (Sakarya terrane) extend from the Black Sea to the IAE Suture to the south, and parallel this suture (Fig. 1). Magmatic units younger than Late Cretaceous-Early Cenozoic are widespread in the Eastern Pontides. They mainly consist of Late Cretaceous lavas and pyroclastic deposits (period 1: arc type) and Paleocene to Miocene volcanic and plutonic rocks. The Cenozoic magmatism, mainly attributed to an orogenic setting, has adakitic to alkaline affinities and occurred during the Eocene (periods 2 and 3) and the Middle Miocene-Pliocene (period 4) (e.g. Aydin et al., 2008; Karsli et al., 2010, 2011; Eyuboghlu et al., 2012).

\section{East Anatolia (EA)}

The EA magmatism is also widespread: it occurs from the Erzurum-Kars Plateau (EKP) to the north to the Bitlis Suture to the south (Fig. 1). It consists of 300-350 m of Plio-Quaternary subaerial lava flows and pyroclastic deposits (period 4) covering a huge area of about 15,000 $\mathrm{km}^{2}$ 
(i.e., Suphan, Nemrut and Bingol volcanoes). The chemical affinities range from mildly alkaline to calc-alkaline (e.g. Pearce et al., 1990), with some reports of tholeiitic compositions (e.g. Özdemir, 2016). On the southern side of the Bitlis Suture, Plio-Quaternary mafic lavas associated with the Karacadag volcano, have alkaline compositions (Pearce et al., 1990; Lustrino et al., 2010; Ekici et al., 2014). A region of intense, recent volcanic activity located to the north of Bitlis Suture has been related to gradual rollback of the Bitlis slab and its subsequent break-off, thereafter responsible for the widespread volcanism and uplift of the region (Şengör et al., 2003; Keskin et al., 2008; Skobeltsyn et al., 2014).

\section{The Lesser Caucasus- NW Iran}

Voluminous magmatism, dated from $80 \mathrm{Ma}$ to the present, extends north-south from the Lesser Caucasus to the Arabian foreland. Late Cretaceous to Eocene transitional high K calc-alkaline to potassic lavas and pyroclastic deposits (period 3) interlayered with sedimentary sequences follow the Lesser Caucasus, the Armenia block and the Talysh Mountains in the north-east border of NW Iran (Vincent et al., 2005). Eocene to Oligo-Miocene lavas and associated plutonic rocks (period 4) with high K calc-alkaline or potassic affinities only occur in Armenia and the NW of Iran (Aghazadeh et al., 2010; Castro et al., 2013; Moritz et al., 2016). Plio-Quaternary eruptions (younger than $3 \mathrm{Ma}$ ) are mainly exposed in the south of the Armenia block parallel to the Lesser Caucasus Suture and consist of medium to high K calc-alkaline mafic to intermediate lavas and pyroclastic deposits (e.g. Neill et al., 2015). In the NW of Iran, Plio-Quaternary volcanoes (Sabalan and Sahand) are characterised by intermediate to felsic lavas; pyroclastic eruptions have calc-alkaline compositions with adakitic affinity (Ghalamghash et al., 2016; Pang et al., 2016). To the north of the Sabalan volcano, magmatic activity with ages ranging from 80 to $11 \mathrm{Ma}$, is dominated by alkaline ultrapotassic and potassic compositions (Aghazadeh et al., 2010; 
Aghazadeh et al., 2015). To the south of the Tabriz fault, evidence of volcanic eruptions is limited; their ages range from $11 \mathrm{Ma}$ to the present (Period 4). The $11 \mathrm{Ma}$ lavas have an alkaline potassic to ultrapotassic composition (Pang et al., 2013b; Shafaii Moghadam et al., 2014; Aghazadeh et al., 2015).

\begin{abstract}
Alborz
The Alborz magmatic belt crops out parallel to the southern margin of the Caspian Sea. It is approximately $600 \mathrm{~km}$ long and $100 \mathrm{~km}$ wide, extending from the Caucasus-NW Iran to the northeast of Iran in Kopet Dagh. Cretaceous to Eocene volcanic activity occurred in the central part of the Alborz and in its western part, Talysh (Vincent et al., 2005; Asiabanha \& Foden, 2012). In the central part of the Alborz an exceptionally thick $(\sim 5 \mathrm{~km})$ Eocene high $\mathrm{K}$ calcalkaline sequence of pyroclastic deposits and lavas (period 3) is known as the Karaj Formation. Quaternary magmatism (period 4) forms several very high summits ( $>4000 \mathrm{~m})$ such as the famous Quaternary strato-volcano "Damavand" $(5671 \mathrm{~m})$, located in the central part of the Alborz. The latter consists mostly of thick alkaline lava flows and subordinate pyroclastic breccia and lahar deposits (Davidson et al., 2004; Liotard et al., 2008; Mirnejad et al., 2010).
\end{abstract}

\title{
Central-East Iranian microcontinent (CEIM)
}

The CEIM includes Central Iran (Yazd and Tabas blocks) and East Iran (Lut block) (e.g., Alavi, 1991). Central Iran is mainly limited by NNE-SSW oriented faults (e.g. Great Kavir and Naiband faults). In Central Iran, there are only a few reports of Eocene magmatic activity (e.g. Amidi et al., 1984; Torabi et al., 2014; Ahmadian et al., 2016). Due to the recognition of Eocene metamorphic core complexes (e.g. Verdel et al., 2007; Kargaranbafghi et al., 2015) and stratigraphic evidence of subsidence during the Eocene, Vardel et al. (2011) suggested that the 
discrete nature of Eocene magmatism (the "flare up" period in Iran) may be linked to slab flattening beneath the Central Iranian blocks. A few younger alkali basaltic outcrops occur along the Great Kavir and Naiband faults (e.g. Saadat et al., 2010; Rajabi et al., 2014; Kheirkhah et al., 2015).

To the east, the main magmatic unit is located around the Lut block (Fig. 1). It has an elongated shape extending over $100 \mathrm{~km}$ from north to south and is bounded by major faults and ophiolitic sutures (period 2). The different volcanic, sub-volcanic and, plutonic units have ages ranging from Jurassic to Quaternary. Jurassic plutonic outcrops (period 1) are restricted to few localities (165-162 Ma; Esmaily et al., 2005). The major magmatic events occurred during the Cenozoic (period 3) and led to the emplacement of various high $\mathrm{K}$ calc-alkaline to potassic rocks (Arjmanzadeh et al., 2011; Pang et al., 2013a; Beydokhti et al., 2015). Recent Quaternary volcanic rocks (period 4), mostly alkaline basalts, erupted along faults (Walker et al., 2009; Saadat et al., 2010; Saadat \& Stern, 2012).

\section{The Urmieh- Dokhtar Magmatic (UDM) zone}

The main magmatic activity in Iran occurs over $1700 \mathrm{~km}$ along the Zagros Suture with a NW-SE orientation: it is named the "Urmieh-Dokhtar magmatic (UDM) zone". This magmatism consists of calc-alkaline and alkaline series emplaced from the Late Jurassic to the Quaternary (Berberian \& King, 1981; Amidi et al., 1984; Aftabi \& Atapour 2000; Omrani et al., 2008, 2009; Torabi et al., 2009; Ghorbani \& Bezenjani, 2011; Ghorbani et.al, 2014). The oldest magmatic events are represented by I-type granitoids that cross-cut late Cretaceous magmatic and sedimentary terranes (Amidi et al., 1984). During the Eocene to the Oligo-Miocene, this magmatism was mostly effusive, with only a rare record of alkaline plutonic rocks (i.e. Dargahi et al., 2010). Some Eocene volcanic and pyroclastic successions (period 3) have a thickness reaching $4 \mathrm{~km}$ (Stocklin, 
1968; Berberian \& Berberian, 1981). The Arabia-Central Iran collision likely triggered delamination of the overriding lithosphere (Francois et al., 2014). These authors showed that such delamination below Central Iran is not correlated with voluminous magmatism after $\sim 30$ Ma, at least along the UMD. Due to the assumption of multi- stage subduction of the Neo-Tethys beneath the TIP (Berberian \& King, 1981; Alavi, 1994; Agard et al., 2005, 2011; Ghasemi \& Talbot, 2006) occurrences of Eocene high-K calc-alkaine magmatism have been interpreted in the context of a continental arc, extension due to slab-roll back and, potentially, tearing (Verdel et al., 2011; Deevsalar et al., 2017), whereas Amidi et al. (1984) proposed intracontinental (possibly rift-related) magmatism for the UDM, based on the occurrence of alkaline magmatism. Plio-Quaternary magmatism (period 4) rarely occurs in the UDM; however, calc-alkaline lavas and pyroclastic eruptions with adakitic signatures have been reported in the central part, parallel to the Zagros Suture (Omrani et al., 2008; Pang et al., 2016). To the northwest (e.g., Kurdistan provinces, Sahand and Sabalan volcanoes and East Pontides), young magmatism with both adakitic and alkaline signatures is observed (Jahangiri, 2007; Ahmadzadeh et al., 2010; Allen et al., 2013; Azizi et al., 2014).

\section{GEOCHEMISTRY}

\section{Chemical classification of lavas}

It is well established that igneous rocks throughout the TIP are ultimately derived from a mantle source, although their extreme geochemical heterogeneity calls for an equivalent lithological and, or, geochemical heterogeneity of this source. The most convincing arguments are Nd-Sr isotope compositions, high $\mathrm{MgO}$ contents and the presence of mantle xenoliths in some lavas, whereas 
geochemical modelling shows that crustal processes play a secondary role (i.e., crustal contamination and, or, fractional crystallization; Özdemir et al., 2006, Lustrino et al., 2010; Asiabanha \& Foden, 2012; Aydin et al., 2008, 2014). In this section, we present a synthesis of the petrological and chemical characteristics of the alkaline magmatic rocks of the TIP, constraining the geochemical characteristics of their mantle sources. In order to minimize the possible effects of shallow processes (e.g., crustal contamination and fractional crystallization) and overprinting of the source characteristics of mantle-derived magmatic rocks, we focus our analysis on rocks with $\mathrm{SiO}_{2}<55 \mathrm{wt} \%$. Such a filtering allows us to exclude plutonic rocks, whose compositions evolved at crustal levels, and results in a dataset that is restricted to lavas with an age $<11 \mathrm{Ma}$. Representative major and trace element data, together with the $\mathrm{Sr}-\mathrm{Nd}$ isotopic compositions of these samples are presented in Table 1 in the Supplementary Data. The lavas can be divided into three main groups: ultrapotassic, potassic to transitional sodic, and sodic, respectively. The geochemical and isotopic characteristics of these three groups are described below.

\section{The Ultrapotassic (UK) lavas}

Based on the IUGS classification and systematic classification for uncommon lavas (e.g. Mitchell \& Bergman, 1991; Woolley et al., 1996), most samples from this group are classified as lamproite, kamafugite, lamprophyre, leucitite, analcite and nepheline-bearing tephrite. On a total alkalis versus silica diagram, all samples plot above the alkaline-subalkaline division line (Fig. 2a). They have low $\mathrm{SiO}_{2}(46.2-55.7 \mathrm{wt} \%)$ and $\mathrm{TiO}_{2}$ contents $(0.8-1.7 \mathrm{wt} \%)$. The $\mathrm{Na}_{2} \mathrm{O} / \mathrm{K}_{2} \mathrm{O}$ ratio is commonly $<1$, with variable $\mathrm{MgO}(1.67-10.8 \mathrm{wt} \%)$ and $\mathrm{Na}_{2} \mathrm{O}(0.72-4.6 \mathrm{wt} \%)$ contents. There is no positive correlation between $\mathrm{SiO}_{2}$ and $\mathrm{K}_{2} \mathrm{O}$, the reverse tendency being observed as the lavas with low $\mathrm{SiO}_{2}$ have an ultrapotassic composition $\left(\mathrm{K}_{2} \mathrm{O}\right.$ contents up to $12.02 \mathrm{wt} \%$, Fig. 2b). In terms of trace elements, even the most primitive lavas are extremely enriched in LILE ( $\mathrm{Rb}, \mathrm{Ba}$, 
Th, $\mathrm{U}$ and $\mathrm{Pb}$ ) and strongly depleted in HFSE and $\mathrm{Sr}$ (Fig. 3a). Their distinctive geochemical characteristics (e.g., extent of LILE enrichment) have never been reported in any other primitive magmatic suites from the TIP. Similarly, ${ }^{87} \mathrm{Sr} /{ }^{86} \mathrm{Sr}$ is significantly high $(0.7056-0.7080)$, whereas ${ }^{143} \mathrm{Nd} /{ }^{144} \mathrm{Nd}$ is low $(0.5124-0.5125)$. The UK lavas plot close to the transitional kimberlites field (Fig. 4).

The transitional sodic to potassic (TK) lavas

Most samples are classified as tephrite and phonolite, whereas a few samples are trachy-andesite (see references listed in Supplementary Data Table 1). Regarding most major elements, this group is similar to the UK lavas, i.e., low in $\mathrm{TiO}_{2}(0.54-1.51 \mathrm{wt} \%)$, and variable in $\mathrm{MgO}(2.75-$ $9.2 \mathrm{wt} \%$ ), but they are moderately lower in $\mathrm{K}_{2} \mathrm{O}(1.1-8.4 \mathrm{wt} \%)$ and higher in $\mathrm{Na}_{2} \mathrm{O}$ (1.46-5.6 wt \%) (Fig. 2b). Contrary to the UK lavas, most of the TK lavas have $\mathrm{SiO}_{2}$ higher than $\sim 50 \mathrm{wt} \%$, positively correlated with $\mathrm{K}_{2} \mathrm{O}$. In terms of trace elements, they are also very similar to the UK lavas, as both groups display negative $\mathrm{Sr}$ and $\mathrm{Ti}$ anomalies (Fig. 3a) and broadly similar subparallel chondrite normalized REE patterns (not shown). The UK and TK lavas show a considerable enrichment in light rare earth elements (LREE) relative to heavy rare earth elements (HREE), but LREE/HREE ratios are not significantly different for the two types of lavas (e.g., $(\mathrm{La} / \mathrm{Yb})_{\mathrm{N}}$ up to $\left.\sim 69\right)$. Elemental ratios involving fluid-mobile elements are higher and more variable in TK than UK lavas (e.g., Ce/Pb: 1.36-29.47 and 1.58-6.88, respectively), whereas those involving more immobile elements display more restricted ranges (e.g. Th/Nb: 0.38-1.7 and $0.4-1.5$, respectively). Interestingly in terms of $\mathrm{Sr}-\mathrm{Nd}$ isotopes, the TK lavas clearly display different isotopic compositions (lower ${ }^{87} \mathrm{Sr} /{ }^{86} \mathrm{Sr}$ and higher ${ }^{143} \mathrm{Nd} /{ }^{144} \mathrm{Nd}$, respectively) compared to the UK lavas. However, all the Sr-Nd isotopic compositions plot within the mantle array (Fig. 4). 
The Sodic- High potassium (HK) and Low potassium (LK) lavas

This group mainly consists of lavas classified as olivine basalt, basanite, hawaiite, mugearite, and trachyandesite (references in Supplementary Data Table 1). These lavas have $\mathrm{Na}_{2} \mathrm{O} / \mathrm{K}_{2} \mathrm{O}>1.5$ $\left(\mathrm{Na}_{2} \mathrm{O}\right.$ and $\mathrm{K}_{2} \mathrm{O}$ ranging from 2.4-6.9 wt \% and 0.3-4.1 wt \%, respectively) and plot within the sodic series field (Fig. 2b). Based on major elements, the lavas are divided into high-K (HK) and low-K (LK) subgroups. The HK subgroup clearly shows high $\mathrm{K}_{2} \mathrm{O}$ (up to 4.1 wt \%), $\mathrm{MgO}$ (7.511.9 wt \%) and $\mathrm{TiO}_{2}\left(1.3-2.3\right.$ wt \%) contents, and a restricted range of $\mathrm{SiO}_{2}(41.9-51.2 \mathrm{wt} \%)$. The LK subgroup is characterized by lower $\mathrm{K}_{2} \mathrm{O}(<2.8 \mathrm{wt} \%), \mathrm{MgO}(1.05-11.9 \mathrm{wt} \%)$ and $\mathrm{TiO}_{2}$ $(0.7-3.5 \mathrm{wt} \%)$ contents, and is relatively more evolved in terms of $\mathrm{SiO}_{2}$ content (46.5- $55.2 \mathrm{wt}$ \%; Fig. 2a).

Primitive mantle-normalised trace element patterns (Sun \& McDonough, 1989) indicate that the level of fractionation of LILE and LREE relative to HREE decreases from the HK to LK subgroups. In addition, in terms of HFSE (e.g. $\mathrm{Nb}$, Ta, and Ti), HK and LK lavas are characterized by positive and negative anomalies, respectively (Fig. 3b). The HK group is characterized by high $\mathrm{Ba}$ (up to $2100 \mathrm{ppm}$ ), Th (up to $40 \mathrm{ppm}$ ), $\mathrm{Sr}(<2800 \mathrm{ppm})$ and $\mathrm{Pb}(>10$ ppm) contents and relatively homogeneous ranges of high $\mathrm{Ce} / \mathrm{Pb}(8.7-20.9)$ and $\mathrm{Nb} / \mathrm{U}(3.3-29.5)$, whereas the LK lavas are characterized by: Ba up to $\sim 1100 \mathrm{ppm}, \mathrm{Th}<20 \mathrm{ppm}, \mathrm{Sr}<1900 \mathrm{ppm}$, $\mathrm{Pb}<13 \mathrm{ppm}$, and highly variable $\mathrm{Nb} / \mathrm{U}(2.7-113)$ and $\mathrm{Ce} / \mathrm{Pb}$ (4.5-85.6). The Nd-Sr isotopic data for the HK lavas plot within the mantle array. These values display a narrow range $\left({ }^{87} \mathrm{Sr} /{ }^{86} \mathrm{Sr}\right.$ : $0.70441-0.70599$ and ${ }^{143} \mathrm{Nd} /{ }^{144} \mathrm{Nd}: 0.51263-0.51273$ ) within the OIB field. In contrast, the LK lavas have highly variable ${ }^{87} \mathrm{Sr} /{ }^{86} \mathrm{Sr}(0.7036-0.7067)$ and ${ }^{143} \mathrm{Nd} /{ }^{144} \mathrm{Nd}(0.51261-0.51297)$ and define a wide range plotting between depleted and enriched mantle sources (Fig. 4). 


\section{Salient conclusions of the geochemical synthesis}

The geochemical overview presented above shows that the variable enrichment in terms of major alkali elements ( $\mathrm{Na}$ and $\mathrm{K}$ ), the LILE and REE fractionation, as well as the $\mathrm{Sr}-\mathrm{Nd}$ isotopic heterogeneity of the lavas may be related to heterogeneous mantle sources. Most lavas plot close to the field of melts derived from enriched mantle sources (e.g. OIB or transitional kimberlites in Fig. 4). Previous studies have shown that the mantle source of the UK and sodic lavas was influenced by metasomatism and underwent only low degrees of partial melting (Allen et al., 2013; Pang et al., 2013b; Shafai Moghadam et al., 2014; Saadat et al., 2014; Prelević et al., 2014, Neill et al., 2015). Moreover, based on the occurrence or the lack of negative HFSE anomalies, the UK and sodic lavas can be sub-divided into types with "subduction-influenced" and "OIBlike" trace element patterns, respectively (Fig.3). In all cases, OIB-like patterns have been explained partial melting of an upwelling enriched asthenospheric mantle source and, or, a hybrid source resulting from the interaction between the asthenosphere and the overlying lithosphere (Wilson et al., 1997; Özdemir \& Güleç, 2014; Neill et al., 2015). The "subduction-influenced" trace element patterns are interpreted as evidence of a shallow mantle reservoir characterised by HFSE depletion (e.g., subcontinental lithospheric mantle SCLM) (e.g., Shafai Moghadam et al., 2014).

Among worldwide "exotic" composition magmatic rocks (e.g. kimberlites, lamproites and lamprophyres), some lavas display "subduction-influenced" patterns, extremely rich in $\mathrm{K}_{2} \mathrm{O}$, low in $\mathrm{SiO}_{2}, \mathrm{TiO}_{2}$ and $\mathrm{Al}_{2} \mathrm{O}_{3}$ (e.g. Gaussberg lamproites: Murphy et al., 2002; olivine lamproites: Mitchell \& Bergman, 1991, and in this study the UK lavas). These compositions are usually associated with the presence of phlogopite phenocrysts, a mineral also common in metasomatized 
mantle xenoliths. Based on laboratory experiments, phlogopite, a K-bearing phase, is a reasonable candidate in the mantle to explain high potassium contents in partial melts (Condamine \& Médard, 2014; Condamine et al., 2016). Such experiments show that the stability field of phlogopite ranges from 1 to $3 \mathrm{GPa}$ and $\sim 900$ to $\sim 1250{ }^{\circ} \mathrm{C}$, i.e., conditions typical of continental lithosphere with a residual heat flow $<40 \mathrm{~mW} / \mathrm{m}^{2}$. However, none of the experiments carried out at shallow lithospheric conditions (1-3 GPa), can explain the main characteristics of lamproites and thus, by extension, those of the UK lavas considered in this study. For example, melts derived from low degree of melting of phlogopite-bearing harzburgite or lherzolite at $\sim 1$ GPa have $\mathrm{SiO}_{2}$ of 52-63 wt \% and $\mathrm{K}_{2} \mathrm{O}$ contents up to 6.6 wt \% (Condamine \& Médard, 2014), whereas, at greater depths (i.e. $3 \mathrm{GPa})$, partial melts have lower $\mathrm{SiO}_{2}\left(45-47.8\right.$ wt \%) and $\mathrm{K}_{2} \mathrm{O}$ up to $7.5 \mathrm{wt} \%$, but high $\mathrm{TiO}_{2}(>\sim 1.5-3.2 \mathrm{wt} \%)$ (Condamine et al., 2016). Although all previous experiments emphasize that the potassium content of partial melts is strongly influenced by the alkali content of phlogopite, Wang et al. (2017) have shown that the potassium content of the melt does not necessarily require the presence of phlogopite in the mantle source, and may result from the heterogeneous composition of a depleted mantle source mixed with recycled sediments. Although the composition of the melt in their experiments is extremely rich in trace elements with a "subduction-influenced" normalised trace element pattern, it is higher in $\mathrm{SiO}_{2}(65.5-68.5$ wt \%) and lower in $\mathrm{K}_{2} \mathrm{O}$ (up to $5.09 \mathrm{wt} \%$ ) than the UK lavas (and low $\mathrm{SiO}_{2}$ lamproites).

Actually, several processes may explain "subduction-influenced" trace element patterns: (i) the presence of minerals with high partition coefficients for HFSE, e.g., rutile, ilmenite, amphibole (Green \& Pearson, 1987; Ionov \&Hoffman, 1995; Tiepolo et al., 2001); (ii) a HFSE-depleted mantle reservoir (e.g., subducted slab or extremely depleted mantle; Saunders et al., 1988;McDonough, 1990; Prelević et al., 2008); or (iii) other processes not directly linked with the source, e.g., crustal contamination during magma ascent (Barth et al., 2000). However, the 
subduction-influenced trace element patterns of low- $\mathrm{SiO}_{2}$ lamproites and $\mathrm{UK}$ lavas are characterized by trace element enrichments several orders of magnitude higher than those of typical continental crust, a feature which has never been observed in any primary melt originated from a studied subduction zone-related mantle wedge (e.g., in a volcanic arc). High pressure experiments indicate that the major characteristics of low- $\mathrm{SiO}_{2}$ lamproites can result from a contribution of continental sediments recycled at MTZ depths. More precisely, the subductioninfluenced trace element patterns can be attributed to sediments particularly low in $\mathrm{SiO}_{2}$ and high in $\mathrm{K}_{2} \mathrm{O}$ (e.g., Rapp et al., 2008; Grassi et al., 2012). In this study, we show that the rise of subducted volatile rich material recycled in the MTZ may explain the occurrence of the UK, TK, sodic-HK and -LK lavas of the TIP.

\section{UPPER MANTLE TOMOGRAPHY BENEATH THE TIP AND IDENTIFICATION OF COMPACTION POCKETS}

\section{Regional distribution of low velocity anomalies through the Upper Mantle}

Numerous high-precision seismic tomography images of the TIP have been published during the last decade. We interpreted tomographic images (Figs. 5, 6) based on S or P wave anomaly models encompassing Central Anatolia (Fichtner et al., 2013), the Caucasus (Koulakov et al., 2012) and the Lut Block (Motaghi et al., 2015), along with the Alinaghi et al. (2007) model which covers most of the TIP (e.g. Fig. 5c). All these models are based on body wave inversion data. Therefore only seismic anomalies larger than the Fresnel volume could be detected: the latter is estimated to be about $10 \mathrm{~km}$ wide at crustal depths and increases to about $50 \mathrm{~km}$ at depths in the upper mantle (Alinaghi et al., 2007). In addition, the resolution of such models is directly 
linked to the density of body wave crossing points, which below the TIP are high enough to provide a separation power of $\sim 50 \mathrm{~km}$ at mantle depths. In addition, Fichtner et al. (2013) also incorporated surface waves in their data inversion, providing a very precise model resolution $(\sim 10-20 \mathrm{~km})$ at crustal and lithospheric levels. These maps highlight several low velocity elliptical bodies ( $\sim 100-150 \mathrm{~km}$ along the shortest axis and $200 \mathrm{~km}$ along the longest axis), which have never been identified previously in any geophysical studies. In the present study, we interpret them as resulting from the compaction of volatile-rich melts rising from the MTZ that we call "Compaction Pockets" (CPs).

The stress field deduced from the GPS velocity field (adapted from Aktug et al., 2013 and Masson et al., 2014) and the distribution of young lavas $(<11 \mathrm{Ma})$ is illustrated in Figs 5 a and c. We note that all the lavas described in previous sections are located in zones where the direction of maximum tension $\left(\vec{\sigma}_{3}\right.$, or least compressive principal stress) is horizontal or what is equivalent the $\left(\vec{\sigma}_{1}, \vec{\sigma}_{2}\right)$ plane is vertical. In the following, we stress in more detail the link between the distribution of these lavas and the presence of CPs below the TIP.

In Central Anatolia, vertical tomography sections (Figs 6c and d) show that the CPs identified above $\sim 300 \mathrm{~km}$ depth are centered at a depth of $\sim 150 \mathrm{~km}$. To the east, an elongated low velocity band including several CPs occurs between $\sim 38^{\circ} \mathrm{E}$ and $54^{\circ} \mathrm{E}$ (Fig. 5c): this initiates along the North Anatolian Fault, follows the Lesser and Greater Caucasus Mountains, through the northwest of Iran and finally ends below the Alborz range. The vertical section of the body wave tomography model from Koulakov et al. (2012), joining the Greater Caucasus to the BitlisZagros Suture, is illustrated in Fig. 6a. Successive CPs reaching a maximum depth of $\sim 350 \mathrm{~km}$ appear to be separated by vertically oriented high velocity sheets. However, the huge volcanic region of East Anatolia is an important exception to the correlation between the location of young volcanism, CPs, and the estimated stress field at the surface (Fig. 5c). This volcanic field is 
actually located above a flat, high velocity body lying at 120-210 km depth (see Figure 9 in Skobeltsyn et al., 2014). This high velocity anomaly may be directly linked to the gradual rollback of the Bitlis slab and its eventual break-off (Şengör et al., 2003; Keskin, 2003; Skobeltsyn et al., 2014) or alternatively to post-collisional delamination of the East Anatolia lithosphere (Göğüş et al., 2011; Özacar et al., 2010) and the associated upwelling of hot asthenosphere. Further south parallel to the Zagros Suture, young magmatism rarely occurs; however, recent magmatic activity, e.g., the Kurdistan province and the Central UDM, is observed in the vicinity of CPs (numbers 12 and 21, respectively in Fig. 5c). Similarly, in the Central Alborz, the Damavand volcano is located at the border of CP number 13 and over a thrust fault in an extensional zone (Fig. 5c).

In the eastern part of Iran, we identified seven individual CPs, clearly disconnected from each other and close to active strike-slip faults (Walker et al., 2009); young volcanic activity occurs close to these faults (Fig. 5c).

\section{Large-scale tomography of the MTZ beneath the TIP}

Figure 7 displays horizontal cross-sections at $500 \mathrm{~km}$ and $700 \mathrm{~km}$ depth through the P-wave tomography model of Nafi Toksöz et al. (2010), which extends from $20^{\circ} \mathrm{E}$ to $60^{\circ} \mathrm{E}$ and from $0^{\circ}$ $\mathrm{N}$ to $50^{\circ} \mathrm{N}$ across the boundary between the Africa-Arabia and Eurasian plates. Because of the scarcity of the crossing points of the ray paths, the resolution of this model is much lower than that of the regional models considered above. In both cross-sections we superpose the $150 \mathrm{~km}$ depth limit of various CPs: these CPs are located inside or at the border of a high velocity band. Around this high velocity band lies a "slow" band oriented north-south, which originates at the Afar triple junction (ATJ) and extends through the Arabian plate up to the Bitlis Suture zone (number 1 in Fig. 7b). Another slow velocity domain is identified, east-west oriented, following 
the Kopet-Dagh, which ends below the Kura Basin, disappears below the Caucasus and finally reappears below the Black Sea (numbers 2 and 3 in Fig. 7b, respectively). At MTZ depths, the velocity contrast between high and low velocity regions represents $\sim 2 \%$, a value often attributed to a temperature variation of $\sim 200^{\circ} \mathrm{C}$ (Piromallo \& Morelli, 2003; Özacar et al., 2008; Faccena et al., 2014).

The above observations are consistent with a rising flow of hot lower mantle associated with the Afar plume, crossing the spinel-perovskite interface and intruding the upper mantle (Faccena et al., 2014; Koulakov et al., 2016). However, this tomography model shows that this hot material does not penetrate into the MTZ below the TIP, which is consistent with recent advances in our knowledge of whole mantle dynamics. Firstly, the spinel-perovskite phase transition is endothermic and slows down convection. However, convective flow may cross this interface for a Clapeyron slope ranging from $-2 \mathrm{MPa} / \mathrm{K}$ to $-3 \mathrm{MPa} / \mathrm{K}$ (e.g. Monnereau \& Rabinowicz, 1996). Second, when a subducting slab meets an ascending lower mantle megaplume, the strong temperature difference between the slab and the mega-plume locally induces a layered convection pattern. In other words, the slab remains trapped for several tens of Myr in the MTZ (e.g. Özacar et al., 2008), and the mega plume remains confined underneath within the lower mantle (e.g. Fukao et al., 2001; Adam et al., 2015). In our study area, the zone of stagnation of slabs extends from the Zagros-Bitlis Suture to the south up to the southern part of Eurasia to the north. In between, no hot mantle plume appears to cross the MTZ, in agreement with tomographic observations (e.g. Nafi Toksöz et al. 2010; Alinaghi et al., 2007; Koulakov et al. 2012).

We furher note that the huge volume of cold material intruded in the MTZ likely cooled the whole upper mantle by a few hundred ${ }^{\circ} \mathrm{C}$ (e.g. Rabinowicz et al., 1980), since the subduction of the Tethys along the Zagros-Bitlis Suture, which started 200 to 300 Ma ago (Şengör \& Yilmaz, 
1981; Yilmaz et al., 2000; Stampfli et al., 2002; Hassanzadeh \& Wernicke, 2016) and ended 80 Ma to 10 Ma ago (Berberian \& King, 1981; Alavi, 1994; McQuarrie et al., 2003; Ghasemi \& Talbot, 2006; Agard et al., 2005, 2011).

These observations of the tomographic structure below the TIP raise the question of the deep origin of the CPs. Clearly, the dramatic velocity contrast between the CPs and the surrounding mantle $(\sim 10 \%)$ requires the presence of at least a few percent of interstitial melt or of several percent of hydrous solid phases (e.g. Hammond \& Humphreys, 2000; Hacker \& Abers, 2004). However, mantle which is a few hundred ${ }^{\circ} \mathrm{C}$ below the temperature of the standard adiabat and starts to melt at $\sim 300 \mathrm{~km}$ depth is likely rich in volatiles. Thus we conclude that the low velocity of CPs must result from the occurrence of a few percent of volatile-rich melt coming from below.

\section{STAGNANT SLAB DIFFERENTIATION AND THE GENERATION OF “COMPACTION POCKETS"}

\section{Development of cold wet diapirs at the top of the MTZ}

The physical and chemical evolution of stagnant slabs and delaminated continental lithosphere leads to the formation of a compositional gradient from eclogite to harzburgite from the base to the top of the MTZ. Harzburgite has a density $1 \%$ to $2 \%$ lower than that of eclogite and lherzolite (Shorttle et al., 2014), implying that this horizon is gravitationally unstable (Rayleigh Taylor instabilities) and may form diapirs intruding the overlying mantle (Motoki \& Ballmer, 2015). Because $\mathrm{H}_{2} \mathrm{O}$ and $\mathrm{CO}_{2}$ are transported by subduction into the $\mathrm{MTZ}$ and recycled back, as 
evidenced by diamond inclusions, we expect that such a harzburgite horizon is rich in volatiles (e.g. Ohtani et al., 2004). S-receiver functions along a north-south profile running from the Hellenic Trench to the Black Sea show that from $38.5^{\circ} \mathrm{N}$ to $44^{\circ} \mathrm{N}$, the $410 \mathrm{~km}$ discontinuity is characterized by a strong slow reflector down to $\sim 450 \mathrm{~km}$ depth (Supplementary Data Appendix B Fig. 1, Kind et al., 2015). This attenuates to the south and wanes around the Hellenic Trench. This low velocity layer can be interpreted to result from: (i) progressive thickening of the wadsleyite to olivine mineral phase transition zone in the presence of water (van der Meijde et al., 2003); and (ii) partial melting due to the release of water during this phase transition (e.g. Karato, 2011).

Accordingly, this low velocity layer may provide evidence for the presence of carbonated and, or, hydrated harzburgites. First, $\mathrm{H}_{2} \mathrm{O}$-solubility is extremely high in the wadsleyite and ringwoodite mineral phases known to form the MTZ: $\sim 0.9 \mathrm{wt} \%$ and $2.3 \mathrm{wt} \%$, respectively (Demouchy et al., 2005; Pearson et al. 2014). Moreover, at the top of the MTZ when wadsleyite transforms into olivine, $\mathrm{H}_{2} \mathrm{O}$ solubility drops from $0.9 \mathrm{wt} \%$ to $448 \mathrm{ppm}$ (Demouchy et al., 2005; Litasov et al., 2009). Thus, water released during this phase transformation will lead to hydrous melting (e.g. Hirschmann, 2006). Second, the solidus of carbonated peridotite is similar to or lower than that of hydrated peridotite (Fig. 8a). When considered together with the solidus of volatile-rich melt (e.g., kimberlite), this implies that the melt produced inside the olivine stability field can have a kimberlite-like composition. Because of the small wetting angle of such a type of inter-granular melt in the mantle, it likely forms a connected network rendering it permeable, even for an extremely low local melt concentrations of about $10^{-5} \%$ according to Minarik \&Watson (1995). However, a small melt concentration of several $0.01 \%$ is usually considered motionless relative to the host solid mantle due to its low permeability. In contrast, at higher 
concentrations $(>0.1 \%)$ melts can segregate from the mantle and move upwards (Hirschmann, 2010; Keller \& Katz, 2016).

We deduce that two hydrodynamic instabilities can trigger the ascent of kimberlite-like melts from the MTZ below the TIP: (i) the gravitational instability of their host harzburgite and (ii) the percolation of the melt itself within its matrix. At constant viscosity, Rayleigh Taylor instabilities develop with a wavelength $\sim 3 h$ (Houseman \& Molnar, 1997), where $h$ is the thickness of the gravitationally unstable low velocity layer, which in our case is $\sim 3 \times 40 \mathrm{~km}$. Once these diapirs are well developed, their velocity may be approximated by their Stokes' velocity; considering their size $(\sim 120 \mathrm{~km})$, their density contrast with the surrounding mantle $(\sim 1 \%)$ and the viscosity of the asthenosphere $\left(\sim 10^{20}\right.$ Pas, Karato \& Wu, 1993), we obtain an ascent velocity of the order of mantle convection velocities, i.e. $<1 \mathrm{~m} / \mathrm{yr}$. In the next section, we show how a compaction process within this rising mantle mush leads to the formation of CPs (which constitute cold wet diapirs).

\section{Conditions for the development of compaction pockets (CPs) from volatile-rich melts within}

\section{cold diapirs}

The free percolation of a non-reactive melt through a viscous mantle has motivated many studies following the seminal work of McKenzie (1984). These have demonstrated that a major condition for the development of melt-rich, solitary waves in the mantle, or "magmons", is a strong vertical permeability drop at the top of the compaction domain (Scott \& Stevenson, 1984; Wiggins \& Spiegelman 1995; Rabinowicz et al., 2002). Generally, this permeability drop has been associated with a temperature drop from $\sim 1300^{\circ} \mathrm{C}$ to $1170^{\circ} \mathrm{C}$ through the lithosphereasthenosphere convective boundary layer, in which dry mafic melts start to crystallize, explaining 
the drop in the volume of interstitial melt and the decrease in permeability of the mantle (Rabinowicz \& Ceuleneer, 2005).

When seeking to apply a model for compaction waves propagating from the base of the MTZ below the TIP, we note that the CP domains displayed in Fig. $6 \mathrm{~b}$ are entirely located well below the $\sim 100 \mathrm{~km}$ thick TIP lithosphere. This leads us to search for an alternative explanation to the necessary condition of a permeability drop. In the following, we identify multiple stages of permeability drop from $8 \mathrm{GPa}$ to $4 \mathrm{GPa}$, and link them to the successive precipitation of new mineral phases resulting from reactions between volatile-rich melts and the surrounding mantle.

The state of volatile-rich melts and their reactivity in the olivine mantle stability field depend on the presence of alkalis, water and carbonate-carrying phases interacting with the surrounding mantle rocks (Ionov et al., 1993; Konzett \& Ulmer, 1999; Tronnes, 2002; Brey et al., 2008, 2011; Gant et al., 2014, 2017; Girnis et al., 2011; Ghosh et al., 2014; Frezzotti \& Touret, 2014; Mallik \& Dasgupta 2014; Novella \& Frost 2014). Experimental results show that hydrated and carbonated phases are stable over various ranges of pressure and temperature. For example, potassium richterite $\left(\mathrm{KNaCaMg}_{5} \mathrm{Si}_{8} \mathrm{O}_{22}(\mathrm{OH})_{2}\right)$ is a well-known hydrous mineral phase that is stable in the upper mantle between 6.5 and $8 \mathrm{GPa}$ at temperatures $\leq 1300^{\circ} \mathrm{C}$ (Konzett $\&$ Ulmer, 1999). In contrast the stability field of phlogopite $\left(\mathrm{KMg}_{3} \mathrm{AlSi}_{3} \mathrm{O}_{10}(\mathrm{~F}, \mathrm{OH})_{2}\right)$ is limited to pressures $\leq 6 \mathrm{GPa}$ and temperatures up to $1300^{\circ} \mathrm{C}$ (Tronnes, 2002; Enggist et al., 2012; Fig. 8b). Moreover, at $\leq 8 \mathrm{GPa}$ and $\sim 1300{ }^{\circ} \mathrm{C}$, carbonate phases (e.g., magnesite and alkali magnesite) are stable (Brey et al., 2011). Between $5 \mathrm{GPa}$ and $4 \mathrm{GPa}$, magnesite is also stable, but in order to have it coexist with phlogopite temperatures lower than $1200^{\circ} \mathrm{C}$ and $1250^{\circ} \mathrm{C}$, respectively, are required (Enggist et al., 2012). When combining these various phase stability fields and associated changes, it is apparent that critically around $1300^{\circ} \mathrm{C}$ and from $8 \mathrm{GPa}$ to $6.5 \mathrm{GPa}$ (i.e. $\sim 240 \mathrm{~km}$ to $195 \mathrm{~km}$ depth), the reaction of volatile-rich melts with the surrounding mantle will 
lead to the precipitation of richterite and carbonate phases. In addition, between 5 and $4 \mathrm{GPa}$ and from $\sim 1250^{\circ} \mathrm{C}$ to $1200{ }^{\circ} \mathrm{C}$, phlogopite and carbonate phases precipitate (Fig. 8b). This can thus trigger the essential permeability drop required for the development of CPs.

Figure 8 displays the minimum and maximum temperature estimation of the mantle adiabat derived by Katsura et al. (2010), the profiles differing by $100^{\circ} \mathrm{C}$ (yellow shaded area in Fig. 8). We see that except at the wadsleyite-ringwoodite and olivine-wadsleyite phase transition depths, both profiles increase almost linearly with depth, and are consistent with a mantle adiabatic gradient of $\sim 0.5^{\circ} \mathrm{C} / \mathrm{km}$. Moreover, the temperature versus depth profile needed to precipitate either hydrated or carbonated phases must be at least $100^{\circ} \mathrm{C}$ lower than the minimum

adiabat. Since the geochemical fingerprints of alkaline lavas in the TIP show that they originated from upper mantle sources that were metasomatized by hydrous and, or, carbonated melts, we thus deduce that such metasomatism requires a temperature at least $100^{\circ} \mathrm{C}$ lower than the adiabat. This is consistent with the fact that long-lived subduction along the Bitlis-Zagros Suture likely led to a progressive drop in temperature by a few $100^{\circ} \mathrm{C}$ within the upper mantle below the TIP, which is consistent with the interpretation of the tomography models of Nafi Toksöz et al. (2010; see above).

\section{A model of propagating compaction waves for rising mantle melts}

We adapt the dimensionless model proposed by Grégoire et al. (2006) to describe the development of compaction waves, when a partially molten mantle layer with constant melt volume $\phi_{s c}$ meets a horizon with a small melt concentration (Supplementary Data Appendix B Fig.2 ). In this numerical experiment, the compaction length $L$ defines the height reached by propagating fluids connected through the pores of the solid matrix: 


$$
L=\sqrt{\frac{\eta k\left(\phi_{s c}\right)}{\mu \phi_{s c}}}
$$

where $\eta$ and $\mu$ represent the effective bulk viscosities of the mantle and volatile-rich melt, respectively; $k\left(\phi_{s c}\right)$ is the permeability of the partially molten layer with fluid concentration $\phi_{s c}$. The excess pressure $p_{\text {eff }}$ defines the difference between the melt and solid pressures and is integrated along the compaction height $L$ over which the porous network is connected:

$$
p_{\text {eff }}=\delta \rho g \mathrm{~L},
$$

where $g$ is the gravity constant and $\delta \rho$ is the density contrast between the solid matrix and the melt.

The time scale $t_{\mathrm{sc}}$ represents the time taken for the melt to move upwards over a distance of one compaction length :

$$
t_{\mathrm{sc}}=\eta / p_{\mathrm{sc}}
$$

Finally Darcy's velocity $V_{s c}$ is

$$
V_{\mathrm{sc}}=L / t_{\mathrm{sc}}=\frac{\delta \rho \mathrm{LL}^{2}}{\eta} .
$$

Melt concentration $\phi_{s c}$ corresponds to the degree of melting, here assumed to be $0.75 \mathrm{vol} \%$, chosen within the range proposed by Canil \& Scarfe (1990) and Dalton \& Presnall (1998). Maaløe \& Scheie (1982) estimated a permeability $k\left(\phi_{s c}\right)=10^{-15} \mathrm{~m}^{2}$ for rocks with millimetre-size grains $a=1 \mathrm{~mm}$, and melt fraction $\phi_{s c}=1 \%$, whereas Faul (1997) suggested a permeability an order of magnitude lower. Based on recent experimental data the following simple rule is derived (Wark \& Watson, 1998):

$$
k=a^{2} \times \phi_{s c}^{3} / 200(5)
$$

Typical grain sizes of rocks deforming by dislocation creep in the shallow upper mantle are $\sim 3-4$ $\mathrm{mm}$ (Karato \& $\mathrm{Wu}, 1993)$, thus we evaluate $k(0.75 \%)=3 \times 10^{-14} \mathrm{~m}^{2}$. The viscosity $\mu$ of the 
volatile-rich melt (e.g. kimberlite) is inferred to be low because of its low Si content and its high concentrations of $\mathrm{CO}_{2}$ and $\mathrm{H}_{2} \mathrm{O}$. Recent experimental estimates indicate $\mu \sim 1 \mathrm{~Pa}$.s at $5.5 \mathrm{GPa}$ and $1300{ }^{\circ} \mathrm{C}$ (Persikov et al., 2017). Following Karato \& Wu (1993), who estimated a viscosity on the order of $10^{19} \mathrm{~Pa} . \mathrm{s}$ for wet asthenosphere between $300 \mathrm{~km}$ and $100 \mathrm{~km}$ depth, we choose a slightly greater value of $\eta \sim 10^{20}$ Pa.s, assuming that the mantle below the TIP is $100^{\circ} \mathrm{C}$ cooler than the standard adiabat. Finally, between $300 \mathrm{~km}$ and $200 \mathrm{~km}$ depth, the density of a kimberlitic melt varies between $2700 \mathrm{~kg} / \mathrm{m}^{3}$ and $3100 \mathrm{~kg} / \mathrm{m}^{3}$, with a mean of $2900 \mathrm{~kg} / \mathrm{m}^{3}$ (Spera, 1984). Considering that the surrounding mantle density at these depths is $\sim 3600 \mathrm{~kg} / \mathrm{m}^{3}$ (Kaban et al., 2016) an average estimate for $\delta \rho$ is $\sim 700 \mathrm{~kg} / \mathrm{m}^{3}$.

Using the above parameter values, we deduce $L=20 \mathrm{~km}, p_{\mathrm{sc}}=0.15 \mathrm{GPa}$ and $t_{\mathrm{sc}}=\sim 2 \times 10^{4}$ years. We propose the following scenario for the TIP, adapted from Rabinowicz \& Ceuleneer (2005):

(1) Just below the interface between the melt-poor and melt-rich horizon (that we assume to be located just above the stability field of richterite, at a lithostatic depth corresponding to 8 GPa and $1300^{\circ} \mathrm{C}$, a first porosity wave develops which is essentially planar with a vertical thickness $\sim 4 \mathrm{~L}(80 \mathrm{~km})$. The resulting melt impregnation consists of oblate shaped pockets (with an elongated horizontal axis) included inside this planar wave (Supplementary Data Appendix B Fig.2a). Such a planar layer of partially molten material may be viewed as a mantle "mush".

(2) Thereafter (Supplementary Data Appendix B Fig. 2b), this planar wave percolates upwards; at time $t^{\prime}=10(\sim 0.2 \mathrm{Ma})$, the wave has shifted upward by a distance $\sim 5 L(100 \mathrm{~km})$ inside the melt-poor horizon, while a new wave is emplaced just below.

(3) Melt pockets start to individualise from the upper leading wave and concentrate the melt upward to a maximal dimensionless amount reaching $\sim 2 \phi_{s c}(\sim 1.5 \%)$, reaching a height 
(thickness) $\sim 4.3 L(\sim 90 \mathrm{~km})$ and a width (horizontal extent) $\sim 8 L(\sim 160 \mathrm{~km})$. The maximum excess pressure at the top of these melt pockets reaches $\sim 2 p_{\text {sc }}(\sim 0.3 \mathrm{GPa})$.

(4) With time, melt pockets detach from the successive horizontal waves. This leads to the regression of the basal waves, from which melt content eventually transfers into the overlying detached pockets.

(5) Finally, the individual pockets interact (Supplementary Data Appendix B, Fig.2c). The melt contained within a pocket pours inside the one located just above. At this stage, this set of “drop-like" CPs displays a typical spatial distribution consistent with compaction experiments and with steady state solitary wave solutions (Rabinowicz et al., 2001; Cai \& Bercovici, 2016). At dimensionless time $t^{\prime}=20(0.4 \mathrm{Ma})$, melt concentration in these pockets reaches $8 \phi_{s c}(\sim 6 \%)$.

\section{Application of propagating melt compaction waves from inside cold diapirs below the TIP}

After 0.2 Ma (stage b, Supplementary Data Appendix B Fig. 2b) melt pockets in the uppermost wave display dimensions consistent with the CPs observed below the TIP, i.e. $\sim 90 \mathrm{~km}$ high and $\sim 160 \mathrm{~km}$ wide, as well as a consistent spatial distribution with some large pockets overlapping with smaller ones. Nevertheless, the melt concentration inside these pockets remains low with a dimensional value of $2 \phi_{s c}=1.5$ vol\%. However, this value corresponds to a $2 \mathrm{D}$ approach and the melt should in fact rather concentrate in two orthogonal horizontal directions leading to a reasonable estimate of melt content in the pockets of $4 \phi_{s c}=3 \mathrm{vol} \%$. Actually, the primary wave from stage $a$ assimilates a first buoyant layer wave that initially forms at $8 \mathrm{GPa}(\sim 240 \mathrm{~km}$ depth$)$ and which thereafter rises during $1.2 \times 10^{5}$ yrs by a height of $\sim 120 \mathrm{~km}(\sim 6 L$, see above $)$ to reach $\sim 120 \mathrm{~km}$ depth. The mean vertical Darcy velocity of the melt is $10 \mathrm{~km} / 2 \times 10^{5} \mathrm{yrs}=0.5 \mathrm{~m} / \mathrm{yr}$, a velocity similar to that of mantle convection. 
Contrary to the end of the numerical experiment (stage c, Appendix B Fig. 2c) the CPs below the TIP may not all individualize because that would require vertical propagation over several hundred kilometers. Instead, they are trapped at the base of the lithosphere at ca. $100 \mathrm{~km}$ depth.

This model explains how melt disseminated inside a cold-wet diapir may migrate upwards from the top of the low velocity layer at $410 \mathrm{~km}$ depth to concentrate at ca. $120 \mathrm{~km}$ depth and form the low velocity elliptical structures observed in tomography sections below the TIP. It represents an alternative to the models developed by Litasov et al. (2013) and by Morra et al. (2015) in which $\sim 1 \mathrm{~km}$-size magmons form at $410 \mathrm{~km}$ depth and thereafter aggregate to form 100 km-size structures. Actually, a major difference between these two models and ours stands in the 4 orders of magnitude difference in the assumed effective viscosity of the partially molten mantle: in our study it equals $\sim 10^{20}$ Pa.s, whereas in Litasov et al. (2013) and Morra et al. (2015) it approaches $\sim 10^{16} \mathrm{~Pa}$.s. A viscosity of $10^{20} \mathrm{~Pa}$.s for wet cold mantle $\left(100^{\circ} \mathrm{C}\right.$ below the mantle adiabat) is realistic. Mei et al. (2002) set experimental constraints on the influence of partial melting on mantle viscosity, and obtained an exponential melt-weakening factor proportional to $\exp (-\alpha \phi)$, with $20<\alpha<30$. However the volume of volatile-rich melt produced during hydrous melting $\phi$ is $<1 \%$ (see below), which leads to a decrease in mantle viscosity by at most $30 \%$. Consequently, a mantle with $1 \%$ of interstitial melt is unlikely to have a viscosity as low as $10^{16}$ Pa.s.

The basic dynamics of our model show that the excess pressure at the top of a CP (just below the zone of obstruction due to crystallization of new mineral phases, e.g., richterite), varies from 0.14 to $0.52 \mathrm{GPa}\left(1 \times p_{\text {sc }}\right.$ to $3 \times p_{\text {sc }}$; Supplementary Data Appendix B Fig. $\left.2 \mathrm{c}\right)$. Such an overpressure exceeds the tensile yield strength of the asthenospheric mantle by an order of 
magnitude (30-50 MPa; Spera, 1987; Rubin, 1993), and it may eventually lead to the generation of a swarm of propagating cracks filled with melt (i.e. dykes), at a velocity close to that of sound propagation along directions parallel to $\left(\vec{\sigma}_{1}, \vec{\sigma}_{2}\right)$ planes (Nicolas \& Jackson, 1982; Spera, 1987; Sleep, 1988; Rubin, 1993; Grégoire et al., 2006; Keller et al., 2013).

Grégoire et al. (2006) modelled the generation of self-propagating melt-carrying channels from the top surface of a mantle plume head below cratonic lithosphere to interpret the distribution of kimberlite pipes in South Africa. The major difference between our model for the TIP and that of Grégoire et al. (2006) resides in the fact that the asthenospheric mantle viscosity in their mantle plume is an order of magnitude lower than that evaluated for the cold asthenosphere lying below the TIP. This results in both a three-times greater size of the CPs and a three-times greater driving head effective pressure. Nevertheless, the process that drives melt extraction from the top of the CPs remains similar.

\section{How melt is extracted from ascending CPs}

Now we consider the evolution of a CP that develops above the MTZ, migrating upwards in multiple stages as cartooned in Fig. 9. Here, we assume that:

(i) the temperature at depths corresponding to $14 \mathrm{GPa}$ and $8 \mathrm{GPa}$ is $1370{ }^{\circ} \mathrm{C}$ and $1300^{\circ} \mathrm{C}$, respectively (i.e. $\sim 100^{\circ} \mathrm{C}$ less than the Katsura et al. (2010) minimum adiabat, e.g. Fig. 8a),

(ii) the temperature at depths corresponding to $8 \mathrm{GPa}$ up to $4 \mathrm{GPa}$ linearly decreases by $0.5^{\circ} \mathrm{C} / \mathrm{km}$,

(iii) $\phi_{s c}=0.75 v o l \%$,

(iv) $\delta \rho \sim 700 \mathrm{~kg} / \mathrm{m}^{3}$,

(v) the stability field of potassium richterite and, or, the solidus of carbonated peridotite between 8 and $6.5 \mathrm{GPa}$ lies at $1300^{\circ} \mathrm{C}$, 
(vi) the stability field of phlogopite and carbonate phases between 5 and $4 \mathrm{GPa}$ lies at $\sim 1250-1200{ }^{\circ} \mathrm{C}$ (Fig. 8b),

(vii) mineral crystallization occurs at a linear rate of 1.25 vol\% per $5{ }^{\circ} \mathrm{C}$ below the liquidus temperature, i.e. this reaction rate may be expressed as $\frac{\delta \mathrm{T}}{\delta 1 \mathrm{vol} \%}=\frac{5^{\circ} \mathrm{C}}{1.25 \mathrm{vol} \%}=4{ }^{\circ} \mathrm{C} / \mathrm{vol} \%$ (Kavanagh \& Sparks, 2009), and

(viii) the vapour saturated solidus linearly decreases between $5 \mathrm{GPa}$ and $4 \mathrm{GPa}$ from $\sim 1300$ to $\sim 1200{ }^{\circ} \mathrm{C}$ (Fig. 8).

\section{Melt extraction from the MTZ to $\sim 8 \mathrm{GPa}$ (stage 1)}

According to asssumptions (i) and (v), at $8 \mathrm{GPa}$ the solidus temperature of richterite is reached at $1300^{\circ} \mathrm{C}$, so that the interstitial volatile-rich melt starts to precipitate richterite. According to assumption (vii) the full precipitation of $0.75 \mathrm{vol} \%$ of melt may occur after cooling by $3{ }^{\circ} \mathrm{C}$ (corresponding to $0.75 \mathrm{vol} \% \times \frac{\delta \mathrm{T}}{\delta 1 \mathrm{vol} \%}$ ), in other words over $6 \mathrm{~km}$ of decompression (corresponding to a thermal gradient of $0.5^{\circ} \mathrm{C} / \mathrm{km}$ ), inferring that local permeability decreases to about zero over this height, which remains small compared to the compaction length $\mathrm{L}=20 \mathrm{~km}$ (Rabinowicz \& Ceuleneer, 2005). Such a process must then dramatically enhance the growth of the compaction instability, leading to a concentration in melt and an effective pressure corresponding to stage $b$ described above (Supplementary Data Appendix B Fig.2a) between 320 and $240 \mathrm{~km}$ depth. Because of the high effective pressure at the top of this compaction pocket (CP), melt can further flow through dykes propagating along the direction of the $\left(\vec{\sigma}_{1}, \vec{\sigma}_{2}\right)$ plane.

Potasssium (K) Budget. Here we evaluate more quantitatively the volume of magnesite and richterite that would result from the reaction of an interstitial volatile-rich melt with the surrounding mantle at a depth just below $8 \mathrm{GPa}$. For that purpose, we assume that the interstitial 
melt has a kimberlite-like composition and represents a volume of $0.75 \%$ of the mantle. Between $200 \mathrm{~km}$ and $300 \mathrm{~km}$ depth, the density of a kimberlitic melt has a mean value of $2900 \mathrm{~kg} / \mathrm{m}^{3}$, whereas the mantle density at these depths is at $\sim 3600 \mathrm{~kg} / \mathrm{m}^{3}$ (Spera, 1984; Kaban et al., 2016). Considering that the range of $\mathrm{CO}_{2}$ inside a kimberlite melt is $4-13 \mathrm{wt} \%$ (Sparks et al., 2009), we obtain a production of magnesite varying from $1.7 \mathrm{~kg} / \mathrm{m}^{3}$ to $5.4 \mathrm{~kg} / \mathrm{m}^{3}$, which represents a volume of $0.06-0.21 \%$ of the solid rock. In addition, a concentration of $\mathrm{H}_{2} \mathrm{O}$ in the melt varying between 5 and $10 \mathrm{wt} \%$ (Sparks et al., 2009) represents a mass of $1.1-2.2 \mathrm{~kg} / \mathrm{m}^{3}$ and may result in the formation of $53-106 \mathrm{~kg} / \mathrm{m}^{3}$ of richterite (corresponding to a volume of $1.7-3.4 \%$ ). Whereas it is obvious that enough $\mathrm{Mg}$ and $\mathrm{Ca}$ are present in the solid matrix and in the interstitial melt to form both magnesite and richterite, it remains essential to find enough $\mathrm{K}$ for the formation of richterite. In order to provide sufficient $\mathrm{K}\left(2.6 \%\right.$ or $\left.2.7 \mathrm{~kg} / \mathrm{m}^{3}\right)$ to produce $106 \mathrm{~kg}$ of richterite, about $84 \%$ of this $\mathrm{K}\left(\sim 2.2 \mathrm{~kg} / \mathrm{m}^{3}\right)$ must be provided by the ambient mantle. In fact, normal mantle cannot provide this amount of K; however Edgar \& Vukadinovic (1993) showed that clinopyroxene synthesized at high pressure $(>5 \mathrm{GPa})$, low temperature $\left(1250^{\circ} \mathrm{C}-1300^{\circ} \mathrm{C}\right)$ and in equilibrium with a high K-melt actually contains a large amount of $\mathrm{K}$, reaching about $1.3 \mathrm{wt} \%$. We deduce that a high K-melt enriched mantle (harzburgite derived from the MTZ) with less than $5 \mathrm{wt} \%$ of clinopyroxene can provide the $2.2 \mathrm{~kg} / \mathrm{m}^{3}$ of $\mathrm{K}$ needed to form $3.4 \mathrm{vol} \%$ of richterite. This is in agreement with the differentiation model of stacked stagnant slabs proposed by Motoki \& Ballmer (2015), which also assumes a hazburgitic mantle composition at the top of the MTZ, and reproduces rising cold-wet diapirs through the upper mantle.

\section{Melt extraction from 8 to $6.5 \mathrm{GPa}$ (stage 2)}

According to the previous section, melt concentration inside a CP represents at most 3 vol\%. The full crystallization of this melt produces $12{ }^{\circ} \mathrm{C}\left(3 \times \frac{\delta \mathrm{T}}{\delta 1 \mathrm{vol} \%}\right)$ of heat. Assuming that the CP moves 
upwards, this increase in temperature induced by crystallisation is compensated by the decrease in temperature due to adiabatic decompression, implying that the temperature of the $\mathrm{CP}$ remains

near $\sim 1300{ }^{\circ} \mathrm{C}$. Therefore melt solidification can be completed when the top of the CP moves up from $\sim 240 \mathrm{~km}$ depth to $240-\left(12^{\circ} /\left(0.5^{\circ} / \mathrm{km}\right)\right)=\sim 215 \mathrm{~km}$. However, the calculations in the previous section show that while $\mathrm{K}$ in the mantle may form $0.75 \mathrm{vol} \%$ of kimberlite-like melt for richterite to precipitate, it remains unlikely that enough $\mathrm{K}$ is produced to generate $3 \%$ of kimberlitic melt.

At a depth shallower than $6.5 \mathrm{GPa}(\sim 195 \mathrm{~km})$ richterite and, or, carbonated peridotite partially melts (Fig. 8), and the temperature drops below $1300^{\circ} \mathrm{C}$. Partial melting then stops as the temperature crosses the adiabat and as melt concentration reaches the same value as that in CPs at stage 1. When the top of the CP rises above the depth corresponding to $6.5 \mathrm{GPa}$, its driving effective pressure likely becomes lower than at stage 1 because of the increase in its small melt content, thus cutting hydrodynamical connection between the overlying and underlying melts. However between the top of the CP and 6.5 GPa (the richterite stability limit), the effective pressure $\left(p_{\text {eff }}\right)$ may still exceed the tensile strength of the medium (for a height $h=$ $\left.30 \mathrm{~km}, p_{\text {eff }}=\delta \rho g h=210 \mathrm{MPa}\right)$, thus allowing for melt extraction by dyking (stage 2, Fig. 8).

\section{Melt extraction from 5 to $4 \mathrm{GPa}$ (stage 3)}

Between 5 and $4 \mathrm{GPa}$ and because of the adiabatic gradient, temperatures drop from $1250{ }^{\circ} \mathrm{C}$ down to $1235^{\circ} \mathrm{C}$, which are respectively higher and lower than the vapour saturated solidus at corresponding depths (Fig. 8). Such a temperature excess range, together with the lack of stable hydrous phases (Figs $8 \mathrm{~b}$ and c), leads to a maximum melting degree of $7 \mathrm{wt} \%$ at $4 \mathrm{GPa}$ (see above, assumption v). However, as the melt fraction inside the CPs exceeds $5 \%$, the effective 
viscosity of the mantle dramatically drops (Kelemen et al., 1997). This high melt concentration due to hydrous melting leads to a dramatic increase in $p_{\text {eff }}$ at the top of the CPs, and thus to the last stage of melt extraction via dykes (stage 3, Fig. 9). It also leads to a major change in the mode of melt migration (Rabinowicz \& Toplis, 2009) with compaction length decreasing by 2 orders of magnitude and formation of a few km-size pockets of "deconsolidated" mantle, similar to those predicted by Litasov et al. (2013).

\section{Melt ponding and extraction above $4 \mathrm{GPa}$}

At depths shallower than $4 \mathrm{GPa}$, the $1200^{\circ} \mathrm{C}$ isotherm corresponds to the stability field of phlogopite and magnesite (Fig. 8b), which therefore precipitate. Henceforth, this mantle domain tends to become melt-free and to strengthen, with a behavior that is competent and elastic rather than viscous. Accordingly, melts derived from stages 1 to 3 can locally pond and solidify below this interface.

\section{LINK BETWEEN THE PERCOLATION OF VOLATILE-RICH MELT INSIDE CPS} AND THE ALKALINE MAGMATISM OF THE TIP

\section{A combination of continental-like components and depleted mantle as a hybrid source of}

\section{UK melts}

Experimental results indicate that melts originated at $\sim 6$ to $10 \mathrm{GPa}$ (i.e. $\sim 180-300 \mathrm{~km}$ depth) from hydrated and, or, carbonated mantle may have geochemical characteristics close to those of lamproites or type II kimberlites (Ulmer \& Sweeney, 2002; Mitchell, 2004; Novella \& Frost, 2014; Brey et al., 2008; Grassi et al., 2012; Girnis et al., 2011; Ghosh et al., 2014). Such melts can be in equilibrium with a harzburgitic mantle (e.g. Girnis et al., 2011). In addition, several petrological and geochemical arguments strongly support the assertion that the unusual 
geochemistry of lamproites results from a hybrid source reservoir, i.e. an extremely depleted mantle peridotite component on the one hand, and a component ultimately derived from a continent (e.g. Prelević \& Foley, 2007; Prelević et al., 2010; Ammannati et al., 2016) on the other hand. Accordingly, the major, trace element and isotopic characteristics of the UK lavas appear to be related to an unusual mantle source enriched by continental-like components.

It must be noted that continental-like components (e.g. phase X or K-hollandite) not only can store $\mathrm{H}_{2} \mathrm{O}$ and $\mathrm{K}_{2} \mathrm{O}$ within the $\mathrm{MTZ}$, but can also be considered as the main reservoirs for LILE (e.g. Rb, Cs, Rb, Ba and $\mathrm{Pb}$ ), and may explain the extreme enrichment of lamproites in trace elements (Konzett \& Fei, 2000; Rapp et al., 2008; Grassi et al., 2012). In Fig. 10a, MORBnormalized trace element patterns for UK lavas are compared with those of MTZ-derived Gaussberg lamproites (Murphy et al., 2002) and average continental crust from NW Iran (Shahzeidi et al., 2017). As evidenced by this figure, the REE concentrations of the UK lavas nearly extend to those of the MTZ-derived lamproites, whereas the LREE enrichment and HREE depletion of the Gaussberg lamproites and UK lavas relative to continental crust are higher and lower, respectively. Murphy et al. (2002) argued that such features could not represent crustal contamination (because, in the case of contamination, LREE enrichment should decrease due to the extremely high REE content of the UK magmas). In addition, the positive $\mathrm{Pb}$ and negative $\mathrm{Sr}$, $\mathrm{Nb}$ and Ta anomalies observed in MORB-normalized trace element patterns disappear when normalized to GLOSS (Fig. 10b). In fact, the normalization to GLOSS values (Plank \& Langmuir, 1998) removes the imprint of continental crust (i.e. $\mathrm{Pb}$ ) and of processes linked to dehydration during subduction (i.e. HFSE: Nb, Ta, Ti, see Murphy et al., 2002) on the concentrations of trace elements. Moreover, studies of garnet-melt HFSE partitioning during partial melting show that HFSE compatibilities are affected by the physical properties of garnet and its composition (Westrenen et al., 2001). Accordingly, it is not valid to use the high HFSE 
contents of garnet as a proxy for the depth of melting. This implies that the HFSE depletion of lamproites could indicate a link with a source located at MTZ depths (e.g. Murphy et al., 2002; Rapp et al., 2008). In fact, the HFSE contained in most melts worldwide may be linked to heterogeneous enriched and depleted lithologies sinking into the mantle, i.e., eclogite (garnet-rich component) and harzburgite, respectively. Thus harzburgite as a mantle reservoir plays a role for HFSE depletion in the MTZ (e.g. McDonough, 1991; Niu \& Hekinian, 1997). Consequently, we propose that a depleted mantle enriched in continental-like components (similar to a "harzburgite-like peridotite" component) can be considered as a specific hybrid mantle source of UK lavas inside the CPs at a pressure greater than $8 \mathrm{GPa}$.

\section{Hydrated and carbonated mantle source and the origin of sodic melts}

It is well documented that the mantle sources of a majority of alkali basalts with OIB-like trace element patterns and Type I kimberlites are located at great depth and require the presence of additional components such as recycled oceanic and, or, continental crust-derived components (Willbold \& Strack, 2006; Pilet et al., 2008; Davis et al., 2011; Sokol \& Kruk, 2015). In terms of trace element contents and Sr-Nd isotopic ratios, our classified sodic-HK lavas have the characteristics of OIB-like alkali basalts, i.e., enriched in LILE and HFSE; however, they also have a transitional composition between OIB and Type I kimberlites (Fig. 3b). Based on our model, at stage 2 (Fig. 9b) the melts in equilibrium with peridotite should display a geochemical fingerprint reflecting the occurrence of K-rich hydrated-carbonated phases. For example, Krichterite in the mantle is a major phase which hosts the LILE, its presence in the source leads to high $\mathrm{K}_{2} \mathrm{O}$, $\mathrm{TiO}_{2}$ and $\mathrm{Rb} / \mathrm{Ba}$, and positive HFSE anomalies (Wagner \& Velde, 1986; Gregoire et al., 2003). However, sodic-HK lavas differ by having commonly higher $\mathrm{Nb} / \mathrm{Ta}$ : $15.8-21$ and Zr/Hf: 40-50 ratios than those of typical OIB: 15.9 and 37.5-45, respectively, e.g., Pfäner et al., 
2007). This is consistent with the fact that low degrees of melting of fertile peridotite produce super-chondritic Nb/Ta melts (e.g. Green, 1995, Ionov et al., 1993). Moreover, similar trace elements patterns to Type I kimberlites and high $\mathrm{Zr} / \mathrm{Hf}$ ratios may provide evidence of a significant role for carbonate metasomatism in their source (e.g. Dupuy et al., 1992; Ionov et al., 2002). Mallik \& Dasgupta (2014) demonstrated that high $\mathrm{CO}_{2}$ contents in bulk melt-rock (hybrid mantle) systems lead to silica undersaturation and to the formation of strongly alkaline OIB-like melts. They also point out a positive correlation between the $\mathrm{CO}_{2}$ content of the reactive system and the increasing degree of silica undersaturation and, or, alkalinity of the melt. The sodic-HK lavas have a higher alkalinity index and lower silica content than those of sodic-LK lavas (Fig. 11a). Finally, we suggest that the parental melts of the sodic-HK lavas were derived from partial melting of a K-richterite- and carbonate-bearing peridotite.

At depths corresponding to pressures of 4-5 GPa, none of the precipitated hydrated and carbonated mineral phases from stage 2 are stable within the temperature range of stage 3 (cf., Fig 8 and the compaction model section above). Partial melting of a hybrid mantle source at such depths is expected to be able to form the parental liquids of classical OIB (e.g., Hirschmann et al., 2003). Interestingly, sodic-LK lavas have major and trace element compositions similar to OIB, but differ from sodic-HK lavas (e.g. Fig. 3) in their lower $\mathrm{K}_{2} \mathrm{O}$ contents and $\mathrm{Rb} / \mathrm{Sr}$ ratios, which is in agreement with the absence of K-richterite during stage 3. Moreover, sodic-LK lavas have variable Sr-Nd isotope compositions (Fig. 4). Such variability is explained by the low degree of partial melting of a hybrid depleted and enriched mantle source (e.g. Kheirkhah et al., 2015). Sodic-LK lavas show a positive correlation of $\mathrm{K}_{2} \mathrm{O}$ with increasing ${ }^{87} \mathrm{Sr} /{ }^{86} \mathrm{Sr}$ (Fig. 12a) and the highest values of ${ }^{143} \mathrm{Nd} /{ }^{144} \mathrm{Nd}(>0.5128)$ are found in samples with high $\mathrm{Na}_{2} \mathrm{O}$ contents $(>4$ wt \%). An interesting point is that a mixing model between UK lavas and sodic-LK lavas (i.e., samples with high ${ }^{143} \mathrm{Nd} /{ }^{144} \mathrm{Nd}: 0.5129$ and low $\mathrm{SiO}_{2}: 50.95 \mathrm{wt} \%$ and $\mathrm{K}_{2} \mathrm{O}: 1.11 \mathrm{wt} \%$ ), not only 
could explain the isotope heterogeneity of the lavas, but could also well explain their trace element contents (Figs 3 and 12a-c). Therefore, we propose that the parental melts of the sodicLK lavas originated from partial melting of the top of the CP during stage 3, their overall composition becoming changed subsequently during mixing processes.

\section{The formation of TK lavas: mixing of variable compositions and heterogeneity of the mantle source}

Several studies (e.g. Waters, 1987; Grégoire et al., 2003) have shown that volatile-rich melts originating from deep-seated mantle sources could not only lead to the diversity of exotic lavas observed at the surface (e.g. kimberlite and lamproite), but could also crystallize the protoliths of MARID xenoliths (rocks consisting of Mica-Amphibole (K-richterite) -Rutile-Diopside) directly within cratonic upper mantle. Regarding the TIP, particularly in Anatolia, NW Iran and East Iran, ultramafic and mafic cumulate xenoliths originating from different depths have been transported to the Earth's surface by UK and TK lavas (Semiz et al., 2012; Saadat et al., 2014; Prelević et al., 2014; Platevoet et al., 2014; Khezerlou et al., 2017, and Fig. 13a). Considering mineral phase assemblages and textures, it has been suggested that these cumulate xenoliths have a magmatic origin and begin to crystallize from 2.2 to $0.5 \mathrm{GPa}$ (e.g., Semiz et al., 2012; Khezerlou et al., 2017). Exotic parental melts (i.e., kamafugite, lamproite and lamprophyre) have been proposed as the parental magmas of some of these ultramafic cumulates (Prelević et al. 2014; Platevoet et al., 2014; Semiz et al., 2012). Surprisingly the mineral compositions and bulk-rock isotopic ratios of the latter (i.e., ${ }^{87} \mathrm{Sr} /{ }^{86} \mathrm{Sr}: 0.7068-0.7095$ and ${ }^{143} \mathrm{Nd} /{ }^{144} \mathrm{Nd}: 0.5124-0.5126$, Fig. 4 ) are similar to those of the investigated UK lavas. Thus, those cumulates may originate from such UK melts related to our proposed stage 1 of formation of the $\mathrm{CP}$, and indeed crystallize at shallower depths. In addition to this specific group of cumulates, other cumulate xenoliths from the TIP display a 
wide range of Sr and Nd isotopic ratios (Khezerlou et al., 2017; Prelević et al. 2014; Semiz et al., 2012; Saadat et al., 2014). The observation of reverse zoning in clinopyroxenes and of cognate antecrystals and cumulative xenoliths hosted by TK lavas, has been interpreted as evidence of either mixing between melts of different compositions (mostly distinct UK and alkaline, probably sodic) or of the assimilation of solids by liquid phases (Semiz et al., 2012; Platevoet et al., 2014; Prelević et al. 2014). It may explain why TK lavas plot in between UK and sodic-LK lavas in terms of alkalis $\left(\mathrm{Na}_{2} \mathrm{O}\right.$ or $\left.\mathrm{K}_{2} \mathrm{O}\right)$ versus isotopic ratios (Fig. 12a and b).

In addition, the few km-thick deconsolidated mantle that settles at $120 \mathrm{~km}$ depth (4 GPa) along the lithosphere-asthenosphere interface is expected to contain a hybrid volatile-rich melt. It is well documented that such melts are highly reactive when they percolate through the lithosphere, whether the latter has been previously metasomatised or not (Coltorti \& Gregoire, 2008; Ackerman et al., 2013; Grant et al., 2014). Su et al. (2014) reported the occurrence of pyroxenite mantle xenoliths in the sodic-LK lavas from the north of the Lut block. These xenoliths provide valuable direct information on the composition of the lithospheric mantle ( 40$70 \mathrm{~km})$. These authors suggest that the spongy textures of some clinopyroxenes formed as a result of decompression melting within an extensional tectonic regime. We propose instead that such textures could also result from the interaction with, and, or, infiltration of alkali-rich silicate melts, kimberlite-like melts, or low-density fluids through the continental lithosphere, evidencing cryptic metasomatism beneath this region (e.g. Carpenter et al., 2002; Bonadiman et al., 2005; Shaw et al., 2006). Laboratory experiments have shown that the reaction of single crystals of olivine and orthopyroxene with relatively alkali-rich, differentiated products of a primary melt may lead to modal metasomatism and form common hydrous phases (e.g., phlogopite and amphibole at continental lithosphere conditions of 1-1.5 GPa and $900-1000{ }^{\circ} \mathrm{C}$, Grant et al., 2014). Melts derived from the low degree melting of phlogopite-bearing peridotites at pressures 
below 1.5 GPa have $\mathrm{K}_{2} \mathrm{O}$ and $\mathrm{SiO}_{2}$ contents close to some of the TK lavas (Fig 11b). Such a mantle source has been proposed by many authors to explain the origin of similar rocks from the TIP with moderate potassium concentrations (e.g. Prelevic et al., 2012). However, when considering how all the above scenarios combine to explain the composition of the TK lavas, we conclude that the presence of UK, sodic-LK and sodic-HK melts all together not only supports the mixing scenario, but also explains the different compositions of the cumulates and metasomatized lithosphere below the TIP.

\section{MELT TRANSPORT THROUGH THE LITHOSPHERE AND LINKS WITH THE MAGMATISM OF THE TIP}

Above, we explained how volatile-rich melt is transported through the asthenosphere below the TIP. In order to link it with surface volcanism, we must now describe the physical conditions for melt and solid hydrated phase transport through the lithosphere. Because of its inherent complexity, we choose to successively describe situations of increasing complexity. The first question to address is the meaning of the tomography images with respect to the proportions of volatile-rich melt and hydrous mineral phases from below the base of the lithosphere up to the surface. Then, we consider how the CPs eventually delaminate (or corrode) the overriding lithosphere. Finally, we study how melt interacts with the lithosphere.

Compatibility of tomographic models with the presence of volatile-rich melts and, or, hydrous minerals

Specific case below East Iran 
The vertical tomography cross-section across the two CPs identified below East Iran (Fig. 6b, Motaghi et al., 2015) provides important information. In the central part of the $\mathrm{CP}$ and at $\sim 150$ $\mathrm{km}$ depth, S-velocity (Vs) is $3.8 \mathrm{~km} / \mathrm{s}$, as opposed to $\sim 4.6 \mathrm{~km} / \mathrm{s}$ elsewhere. Such a huge difference in velocity $(\sim 15 \%)$ can be explained by the presence of a few percent of inter-granular melt (Hammond \& Humpherys, 2000), giving a first order agreement with our CP model. This tomography model shows that the top of the $\mathrm{CP}$ crosses the reflection interface at $\sim 125 \mathrm{~km}$ depth, previously interpreted as the lithosphere-asthenosphere boundary (LAB, alignment of open squares, Fig. 6b). We may thus infer that this interface represents the boundary between melt free and melt-rich mantle. Actually, as suggested above, the top of the CPs at stage 3 is composed of a deconsolidated mantle mush including $\mathrm{km}$-sized pockets of melt. The temperature there may reach $\sim 1200^{\circ} \mathrm{C}$, corresponding to the stability field of phlogopite, thus allowing for melt solidification. In more detail, the consumption of garnet and enstatite in the presence of $\mathrm{H}_{2} \mathrm{O}$ and K simultaneously leads to the formation of phlogopite and clinopyroxene (e.g. Aoki, 1975). The entire melt eventually completely solidifies around the $4 \mathrm{GPa}$ equivalent depth, corresponding to the hydrous basalt solidus at $\sim 1200^{\circ} \mathrm{C}$. The Hacker \& Abers (2004) Excel worksheet gives $\mathrm{Vs}=3.9 \mathrm{~km} / \mathrm{s}$ for a cumulate of $90 \% \mathrm{cpx}+10 \% \mathrm{phl}$, in agreement with what is observed just above the LAB of the main CP (Fig. 6b).

In addition, a low Vs domain appears centred on the axis of the main $\mathrm{CP}$, just below the crust and down to a depth of $\sim 80 \mathrm{~km}$. This ranges between $3.8 \mathrm{~km} / \mathrm{s}$ and $4.1 \mathrm{~km} / \mathrm{s}$ with respect to surrounding velocities, which vary between $4.2 \mathrm{~km} / \mathrm{s}$ and $4.4 \mathrm{~km} / \mathrm{s}$. Again this marked velocity contrast (up to $\sim 10 \%$ ) must result from the physical properties of mantle minerals, and only hydrous phases can produce such a dramatic effect on seismic velocities (Hacker \& Abers, 2004). The mineral assemblages of cumulate xenoliths derived from depths equivalent to $<\sim 2 \mathrm{GPa}$ pressure below the TIP may in fact be consistent with such seismic velocities (see Fig. 13b for 
their location), and therefore, we used the modal mineral proportions evaluated by Rajabi et al. (2014) and Su et al. (2014) for cumulate and pyroxenite mantle xenoliths, respectively, and incorporated them in Hacker \& Abers (2004) Excel worksheet. The estimated Vs reaches 3.9 $\mathrm{km} / \mathrm{s}$ for cumulates originating from the base of a thick crust ( $\sim 1.5 \mathrm{GPa}$ equivalent pressure $)$ at $600^{\circ} \mathrm{C}$, and $4.3 \mathrm{~km} / \mathrm{s}$ for mantle xenoliths at $\sim 2.2 \mathrm{GPa}$ and $1000^{\circ} \mathrm{C}$. These values are equivalent to those of the S-tomography map (Fig. 6b; Motaghi et al., 2015).

\section{Specific case below the Greater and Lesser Caucasus}

The vertical tomography section across the Arabian plate to the Scythian platform displays three CPs (Fig. 6a, Koulakov et al., 2012). The southern CP is located below the Lesser Caucasus and intrudes the overriding lithosphere over a $\sim 150 \mathrm{~km}$ wide region, and eventually reaches the surface below the Ararat volcano. A further $\sim 200 \mathrm{~km}$ to the north, a second CP partly intrudes the lithosphere and reaches the surface by a narrow conduit connected to the Kazbegi volcano. The third CP occurs below the $150 \mathrm{~km}$ thick Scythian lithosphere. The P-wave velocity (Vp) contrast between the central part of these CPs (at $\sim 200 \mathrm{~km}$ depth) and the surrounding mantle is $8 \%$, a value similar to that found in East Iran, and thus likely results from the presence of melt. At shallower depths (less than $60 \mathrm{~km}$ ), the contrast in velocity between the intruded CP material and the lithospheric mantle reaches up to $11 \%$. From the Abers \& Hacker (2004) Excel worksheet, Vp calculated for cumulate and pyroxenite mantle xenoliths varies between $7.2-7.6 \mathrm{~km} / \mathrm{s}$, whereas it reaches $8.2 \mathrm{~km} / \mathrm{s}$ and $8.3 \mathrm{~km} / \mathrm{s}$ for garnet harzburgite and eclogite, respectively. Accordingly, the observed seismic velocities at lithospheric depths may be explained by partially molten mantle and, or, cumulate and pyroxenite mantle xenoliths. They can be interpreted in terms of the intrusion of hot asthenosphere at these depths; mantle at a temperature of at least $\sim 1300^{\circ} \mathrm{C}$ (e.g. Pilet, 2015) cannot produce the observed alkaline basalts. In contrast a cooler 
temperature is consistent, together with the solidus of vapor-saturated mantle (i.e. $\sim 1000^{\circ} \mathrm{C}$ at 2 $\mathrm{GPa}$ ), and is able to produce such magmas.

\section{Central Anatolia}

Vertical tomography sections (Figs 6c and d) show that Vs ranges from 4.1 to $4.5 \mathrm{~km} / \mathrm{s}$ below Central Anatolia, a value 10\% greater than below East Iran. Such a difference could be explained either by a scaling difference between the tomographic models, or by a greater volume of hydrous solid phases and, or, melts. Figures 5a and b displays seismic velocities at $150 \mathrm{~km}$ and $60 \mathrm{~km}$ depth after Fichtner et al. (2013). The $60 \mathrm{~km}$ deep low velocity domain essentially consists of a strip less than $100 \mathrm{~km}$ wide oriented SE-NW, which follows the Central Anatolian Thrust Belt (CATB, Fig. 5a); In the orthogonal direction, this low velocity domain appears patchy (shown in Fig. 5b), and in between, high velocity zones appear which correlate with sedimentary basins (e.g. Salt Lake and Sivas Basins, Fig. 5b). The maximum velocity contrast between low and high velocity domains again represents $\sim 10 \%$. Henceforth, we deduce that the low velocity zones at $60 \mathrm{~km}$ depth reveal the specific presence of volatile-rich melts and, or, hydrous minerals.

It is important to note that the $60 \mathrm{~km}$ deep low velocity domains appear connected to the $150 \mathrm{~km}$ deep ones, which have a greater extent (i.e., $>200 \mathrm{~km}$ ) and can be identified on the 150 km depth contour map, Fig. 5a, (Fichtner et al., 2013). We deduce that the melts and, or, hydrous minerals at lithospheric depths are fed by the underlying CPs.

According to Kind et al. (2015) the mean thickness of the lithosphere in Central Anatolia is $\sim 70 \mathrm{~km}$, indicating that the low velocity domains at $60 \mathrm{~km}$ depth likely represent areas where the Central Anatolia lithosphere is thinner, whereas the high velocity domains at $60 \mathrm{~km}$ depth relate to a significantly thicker lithosphere, essentially devoid of hydrous minerals. This interpretation is consistent with the presence of sedimentary basins above these domains, which 
could simply result from isostatic equilibration. This explanation does not rule out previous interpretations of these Oligo-Miocene sedimentary basins as resulting from post-collisional tensile tectonics inducing crustal-scale thinning (Francois et al., 2014; Gögüuş et al., 2017).

\section{East Anatolia}

In East Anatolia, the variation in surface wave velocity anomalies at $75 \mathrm{~km}$ depth reaches an amplitude of $12 \%$, but drops down to $4 \%$ at $140 \mathrm{~km}$ depth (see Figure 9 in Skobeltsyn et al., 2014). In particular, the high velocity mantle domain between $125 \mathrm{~km}$ and $200 \mathrm{~km}$ depth has been interpreted as a detached slab-like body located below the most active volcanoes (e.g., Suphan; Keskin, 2003; Pearce, 1990). This body displays a Vs anomaly excess of 4\% at $125 \mathrm{~km}$ depth, which decreases to $2 \%$ at $200 \mathrm{~km}$ depth (Skobeltsyn et al., 2014). These latter values do not require significant partial melting or the presence of hydrous minerals. Therefore, this high velocity body may simply result from a temperature contrast with its surroundings, decreasing from $400^{\circ} \mathrm{C}$ at $125 \mathrm{~km}$ depth to $200^{\circ} \mathrm{C}$ at $200 \mathrm{~km}$ depth. However the $-12 \%$ contrast in mantle velocity at $75 \mathrm{~km}$ depth and above this cold body is still best explained in terms of the presence of melt and, or, hydrous minerals.

\section{How CPs delaminate the overriding lithosphere}

The above analysis of tomographic images indicates that the collision of CPs with the overriding lithosphere either leads to its delamination over a domain a few $100 \mathrm{~km}$ wide (e.g., through Central Anatolia and the Lesser Caucasus) or to narrow intrusions of volatile-rich melts or hydrated solid materials above the CP axes (e.g. East Iran and Greater Caucasus). Two conditions characterise zones of lithospheric delamination. First, GPS data (Masson et al., 2014) show that 
over supposedly delaminated domains, the $\left(\vec{\sigma}_{1}, \vec{\sigma}_{2}\right)$ plane is oriented vertically (i.e., tensile stress field). In contrast narrow intrusions correlate with a compressional state of stress at the surface.

Domains prone to lithospheric delamination coincide with areas where the crust is anomalously thick and, or, hot, which have been attributed to post-collisional extension (Francois et al., 2014; Göğüş et al., 2011). It is important to note that the East Iran region in contrast displays a relatively low heat flux and low topography, indicative of a cold crust (e.g., MotavalliAnbaran et al., 2011).

Whatever the crustal temperature and stress field, the huge buoyancy of the CPs should ultimately lead to the delamination of the overlying lithosphere. Generally, destabilisation of continental lithosphere by negative Rayleigh-Taylor instabilities typically requires several tens of Myr (Houseman \& Molnar, 1997). The collision of CPs with the East Iranian lithosphere may well have led to its delamination within several tens of Myr, whereas below Central Anatolia and the Lesser Caucasus, such delamination seems to have occurred much faster. A stability analysis (Rigo et al., 2015) demonstrated that buoyant asthenosphere can diapirically intrude a $\sim 100 \mathrm{~km}$ thick stretched lithosphere within a few 100 ka if: (i) the tensile stress regime within the lithosphere exceeds its failure threshold; (ii) the lithosphere has a purely plastic rheology when it reaches its yield strength; (iii) the mantle lithosphere is at least 1\% denser than the underlying asthenosphere; (iv) the crust is rheologically decoupled from the mantle lithosphere. This may explain the 100 -150 km wide intrusive mantle horizon below both the Lesser Caucasus and Central Anatolia. However, this scenario cannot apply to the Greater Caucasus, which is reported to be in horizontal compression (e.g. Masson et al., 2014).

\section{Interaction of mantle-derived melts with the lithosphere}


According to our model, the UK, sodic-HK and sodic-LK melts originate from CPs via dyking events that successively occur at $8 \mathrm{GPa}, 6.5 \mathrm{GPa}$ and $4 \mathrm{GPa}$, during stages 1 to 3 . In the following, we describe our understanding of melt pathways before and after the collision of the CPs with the overlying lithosphere.

\section{Melt pathways during the collision of CPS with the overlying lithosphere}

The probability for dykes rising from the top of the CPs at about $150 \mathrm{~km}$ depth to reach the base of the lithosphere increases at the borders of the CPs with respect to their centers (Fig. 9); this is due to the upward flexural bending of the competent (and elastic) continental lithosphere pushed from below by the buoyancy of a $\mathrm{CP}$, which induces horizontal compression immediately above the axis of the CP, and horizontal tension $\sim 100-200 \mathrm{~km}$ away (Gerbault et al., 2017). Accordingly, melt accumulates in elliptical zones at the edges of CPs trapped at the LAB, the thickness of which decreases at their borders with respect to their center. Thereafter, melts will pond as sills within the lithosphere or propagate all the way up to the surface, depending on the tectonic stress. This process of melt focusing at different depths thus depends on the local stress field resulting from the combined effects of the transient visco-elastic response of the lithosphere above CPs, and the "far-field" tectonic stress, such as for instance tectonic compression through East Iran or tectonic extension through Central Anatolia. A complex local state of stress at different depth levels may explain why in both East Iran and Central Anatolia, despite their "opposite" state of far-field tectonic stress, lavas at the surface eventually appear at the borders of the identified underlying CPs.

What happens to melt pathways at the axis of CPs? In the following, we consider two tectonic situations, one where there is no delamination of the overlying lithosphere (e.g. East Iran 
and the Greater Caucasus) and one where there is delamination (e.g. the Lesser Caucasus and Central Anatolia).

No delaminating lithosphere. The underlying CPs vertically compress the viscous portion of the lithosphere as a subsequent response to the horizontal compression induced by flexural elasticity (Gerbault et al., 2017). Since these regions are also under tectonic horizontal compression, the stress field likely rotates by $90^{\circ}$, at some depth above the base of this viscoelastic lithosphere. The elastic thickness of continental lithosphere (e.g., Burov \& Watts, 2006) strongly depends on its composition, thermal state and stress state. For the TIP, we may assume that it is about $85 \mathrm{~km}$ thick, corresponding to the $500^{\circ} \mathrm{C}$ isotherm (as deduced by Burov \& Diament (1995) for the Himalayas). Accordingly, it can be expected that the last sequences of ponding dykes (stage 3, Fig. 9) occurs just above the base of this competent visco-elastic lithosphere, with local variations that depend on its state of stress, based on tomography observations from East Iran or the Greater Caucasus indicating that the accumulation of hydrous materials also occurs at shallower depths near the Moho interface. We propose that slowly developing "reactive elasto-plastic channels" related to the infiltration of melts from the base of the competent lithosphere may eventually percolate upwards and interact with the mantle lithosphere and the crust before reaching the surface (e.g., Keller et al., 2013). Such mechanisms are consistent with the geochemical characteristics of lavas in the Greater Caucasus, which are impacted by shallow level processes (e.g., crustal contamination and fractional crystallization; Lebedev et al., 2003).

Delaminating lithosphere. As mentioned above, lithospheric delamination may occur quasi-instantaneously in comparison to the conductive characteristic time of the lithosphere (i.e. a few 100 kyr vs several Myr). Henceforth the intruded melt or hydrous solid phase material may have a temperature close to that of the vapour-saturated mantle solidus at $4 \mathrm{GPa}\left(1200^{\circ} \mathrm{C}\right)$, 
resulting in softening of the surrounding mantle. We invoke the Kaislaniemi et al. (2014) numerical modelling applied to the TIP to explain how small convection cells within watersaturated mantle may erode the overlying lithosphere. Although this model explains lithospheric delamination, it still remains difficult to apply to the TIP, since it requires temperatures of $1300^{\circ} \mathrm{C}$ at the $\mathrm{LAB}$ depth that these authors chose, i.e., $90 \mathrm{~km}$, which is too elevated to produce the alkaline magmatism observed at the surface. In the model of Kaislaniemi et al. (2014), small convection cells can develop due to a high temperature combined with a water-saturated mantle rheology. Actually, such convection cells, which enable lithospheric delamination, should still be able to develop under a cooler thermal regime with an even softer rheology, which would indeed better represent phlogopite-bearing hydrated mantle material.

\section{TIP volcanism due to the development of CPs or "post collisional processes"?}

The main argument against the role of post-collisional or subduction-related processes in the generation of extensive alkaline magmatism throughout the TIP during period 4 (the last $25 \mathrm{Ma}$ ) is that all models require hot upwelling asthenosphere, associated with slab break-off (Keskin, 2003; Agard et al., 2011) or slab tearing (Jolivet et al., 2013). Similarly, lithospheric delamination resulting from orogenic crustal thickening also leads ultimately to its replacement by hot mantle up to the base of the crust (Şengör et al., 2003; Keskin, 2003, 2005; Özacar et al., 2008; Francois et al., 2014). However, we have shown above that the alkaline magmatism observed throughout the TIP requires a low temperature in the mantle. An alternative explanation for the formation of alkaline melts at a standard temperature of $1300^{\circ} \mathrm{C}$ at the $\mathrm{LAB}$ would be to require the $\mathrm{LAB}$ to be located at $150 \mathrm{~km}$ depth (e.g. Pilet, 2015). Such a thick mantle lithosphere is in fact compatible with the McKenzie \& Priestley (2016) model of a doubled lithospheric 
thickness resulting from the collision of the Arabian and Indian continents with Eurasia, which subsequently thins to its initial thickness during post-collisional extension. However, this is in contradiction with geophysical data indicating that below Central Anatolia, East Anatolia and the Lesser Caucasus the lithosphere is actually thin. If temperatures were high below such a thin lithosphere, then melting of the shallow, hot, convecting sub-lithospheric mantle would erase any signature of low-degree melts at the surface. Our alternative explanation of cold-wet sublithospheric CPs therefore provides a more consistent mechanism for the distribution of alkaline magmatism throughout the TIP.

In the Lesser Caucasus where alkaline magmatism has been interpreted as a result of lithospheric delamination (e.g. Neill et al., 2015), this delamination may not necessarily relate to post-collisional processes, but can also be directly linked to underlying CPs. In the Kurdistan province, Allen et al. (2013) linked the geochemistry of sodic-HK lavas to the occurrence of richterite in their source, which they related to the presence of a thick lithospheric mantle beneath the Zagros Suture. However, sodic-HK lavas also occur away from the Zagros Suture zone where the lithosphere is not thick (e.g. Damavand volcano), and in both cases these sodic-HK lavas are located near the borders of CPs (Fig. 5c), indicating that they might in fact rather be linked to these underling CPs instead of a thickened lithospheric mantle.

Amongst all reported magmatism, the only place where there is an obvious relationship between young volcanism and orogenic processes (e.g. descending slab, slab-break-off) is East Anatolia (e.g. Keskin 2003, 2005). However, the fact that the lavas here have a composition similar to sodic-LK lavas from the surrounding regions (e.g., below the Lesser Caucasus) and that they are associated with a deep low velocity zone located at $450 \mathrm{~km}$ depth (Zhao et al., 2008), further supports the argument that a similar process of migrating CPs can explain the volcanism. 


\section{BACK IN TIME TO DECIPHER CP ACTIVITY}

The subduction history of the Tethys Ocean beneath the TIP provides a natural argument to link magmatic events to classical subduction-related processes. Interpretation of continental arc magmatism for period 1 can be quite straightforward due to: (1) linear structures parallel to the Zagros Suture (SSZ in Fig.1); (2) consistency with the characteristics of classical arc-related calcalkaline magmatism (i.e. I-type granitoids). However, the main problem in the TIP is to interpret the origin and source characteristics of continental magmatism after the emplacement of ophiolites at $\sim 80 \mathrm{Ma}$, (periods 2, 3 and 4), when the timing of the Arabia-Eurasia collision remains controversial.

A long-standing assumption has been that subduction was active during period 3 (e.g. McQuarrie et al., 2003; Agard et al., 2005, 2011; Vincent et al., 2005; Verdel et al., 2011). These authors linked the origin of arc-like magmatism in this period to mantle wedge processes, e.g. cold and hydrated plumes rooted at the slab-mantle wedge interface (Castro et al., 2013), a hydrated mantle located at the top of a flat slab in an extensional arc setting (Verdel et al., 2011), or back-arc basin dynamics (Vincent et al., 2005). On the other hand, many studies have noted that arc-like continental magmatism is not necessarily linked to an active subduction zone (Hawkesworth et al., 1995; Hooper et al., 1995; Wang et al., 2016). These studies have suggested that classical arc magmatism, i.e., calc-alkaline magmatism, may be better explained by lithospheric extension or decompression melting of subcontinental lithosphere metasomatised by MTZ-derived fluids. Moreover, we should recall that the most arc-like volcanic rocks in period 3 have potassic and adakitic signatures, which are also found during period 4, and were previously

attributed to post-collisional processes (Jahangiri, 2007; Omrani et al., 2008; Ghorbani \& 
Bezenjani, 2011; Shabanian et al., 2012; Azizi et al., 2014; Ahmadian et al., 2016; Ghalamghash et al., 2016). When we extend the above reasoning to the entire TIP, we must question whether arc-like magmatism is necessarily related to mantle wedge processes associated with an active subduction zone.

\section{Back in time and traces of CP-derived melts}

Since at least the Cimmerian orogeny $(\sim 200 \mathrm{Ma})$, various subducted lithospheric fragments would have continuously ponded in the MTZ and cooled the upper mantle. In the MTZ, enrichment in $\mathrm{CO}_{2}$ and $\mathrm{H}_{2} \mathrm{O}$ in these essentially harzburgitic slabs would have made their partial melting and differentiation possible, subsequently forming $\mathrm{CO}_{2}$ - and $\mathrm{H}_{2} \mathrm{O}$-enriched diapirs within about 10 Myr (Motoki \& Ballmer, 2015). This timing indicates that the development of CPs, their migration and their collision with the sub-continental lithosphere is only possible when neighbouring orogenic systems reach a pivotal period when sufficient differentiation of subducted material renders the upper part of the MTZ diapirically unstable. We are able to understand these processes in the TIP area because they happened during the last $10 \mathrm{Myr}$ and because the nature and distribution of the magmatism can be directly related to tomographic images and the present-day tectonic stress field. But what happened before?

Based on previous geochemical and petrological studies, both old volcanic and plutonic rocks display a large variety of compositions. Figure $14 \mathrm{c}$ summarizes the correlation of magmatic events with age. From the literature, different magmatic events seem to display variable compositions, but when we look closely at the data, we can identify an important bias due to the different classification schemes being used by different authors. Actually, in a total alkalis 
$\left(\mathrm{K}_{2} \mathrm{O}+\mathrm{Na}_{2} \mathrm{O}\right)$ versus $\mathrm{SiO}_{2}$ diagram the data plot along or above the alkaline trend (Figs $14 \mathrm{a}$ and b). Thus, the alkali contents of all these rocks represent a common feature. We use our proposed model to check if melts derived from CPs could also provide an acceptable explanation for older magmatic rocks up to $80 \mathrm{Ma}$.

\section{Volcanic rocks}

The volcanic rocks of the TIP are classified as alkaline sodic (e.g. Verdel et al., 2011; Yeganefar et al., 2013; Aghazadeh et al., 2015) and potassic, or high K calc-alkaline lavas (e.g. Asiabanha \& Foden, 2012; Aghazadeh et al., 2015). The most primitive high K calc-alkaline lavas are clearly different from classical calc-alkaline suites, with low $\mathrm{SiO}_{2}$ contents and highly alkaline affinities (e.g. Asiabanha \& Foden, 2012). In fact, their chemical characteristics are similar to the young TK lavas, and their origin could be explained by the mixing of high ${ }^{143} \mathrm{Nd} /{ }^{144} \mathrm{Nd}$ and low $\mathrm{K}_{2} \mathrm{O}$ melts with a crustal component (Asiabanha \& Foden, 2012).

Similar to the young lavas, the majority of the older sodic lavas are characterized by low $\mathrm{K}_{2} \mathrm{O}(<\sim 2 \mathrm{wt} \%)$ and $\mathrm{SiO}_{2}(47-55 \mathrm{wt} \%)$ contents and plot within the sodic-LK lavas field. Only few lavas ( $\sim 80 \mathrm{Ma})$ have lower $\mathrm{SiO}_{2}(42.5 \mathrm{wt} \%)$ and higher $\mathrm{K}_{2} \mathrm{O}(1.8-7.1 \mathrm{wt} \%)$ contents, and plot in the sodic-HK lavas field, displaying "OIB-like" trace element patterns. Similar to young sodic-LK and -HK lavas (Fig. 3b), their origin has simply been interpreted as asthenospheric depth derived melts (Verdel et al., 2011; Aghazadeh et al., 2015).

Plutonic rocks 
Magmatism older than $11 \mathrm{Ma}$ is mainly represented by plutonic rocks, particularly from 23 to 80 $\mathrm{Ma}$, in contrast to the alkaline magmatism younger than $11 \mathrm{Ma}$, which is characterized by the absence of plutonic rocks. The plutonic rocks have been divided into Ferroan (A- type), potassic and infracrustal (I- type) high-K calc-alkaline granitoids (e.g. Boztuğ et al., 2007; Dargahi et al., 2010; Karsli et al., 2012b; Castro et al., 2013; Nabatian et al., 2014; Kananian et al., 2014; Moritz et al., 2016; Ahmadian et al., 2016). The chemical characteristics of the granitoids are more complex than those of the volcanic rocks because their parental magmas experienced a variety of processes, including fractional crystallization (Karsli et al., 2012b; Castro et al., 2013; Nabatian et al., 2014; Kananian et al., 2014; Ahmadian et al., 2016). However, all studies strongly argue for hybrid melt origins, among which a mantle-derived component essentially explains their high alkali content and their diversity in terms of trace elements and $\mathrm{Sr}-\mathrm{Nd}$ isotope ratios.

A-type granitoids: combination of an alkaline melt and continental crust. Among the 23-80 Ma plutons, A-type granitoids have high ${ }^{87} \mathrm{Sr} /{ }^{86} \mathrm{Sr}$ (up to 0.7135 ) which positively correlates with $\mathrm{SiO}_{2}$ and have $\mathrm{Y} / \mathrm{Nb}$ ratios $>1.2$, which generally indicates involvement of crustal components (Eby, 1990, 1992). A-type granitoids from the TIP (Fig. 19b) could result from a simple hybridization process between fractionated sodic-LK lavas and crustal melts (Figs 12d-f). The sample with the lowest ${ }^{87} \mathrm{Sr} /{ }^{86} \mathrm{Sr}(0.7051)$ and $\mathrm{SiO}_{2}\left(50.76\right.$ wt \%) content has a low $\mathrm{K}_{2} \mathrm{O}$ content (2.68 wt \%), high $\mathrm{Na}_{2} \mathrm{O}$ content $\left(3.52 \mathrm{wt} \%\right.$ ) and high ${ }^{143} \mathrm{Nd} /{ }^{144} \mathrm{Nd}(0.5127)$, similar to the more recent sodic-LK lavas (Fig. 12). This is in good agreement with the general scenario explaining their origin: they would originate from a mantle-derived alkaline melt that underwent, or not, crustal assimilation processes as well as compositional changes during efficient fractional crystallization (Boztuğ et al., 2007; Karsli et al., 2012a). 
Potassic granitoids: lithospheric depth processes. Potassic granitoids rocks are numerous from $\sim 25$ to $\sim 60 \mathrm{Ma}$. Interestingly these granitoids have a distinguishable composition from that of the 100-200 Ma I-type granitoids from the Sanandaj-Sirjan Zone (SSZ parallel to the Zagros Suture, Fig 1); for example, the most mafic potassic plutonic rocks have higher amounts of total alkalis and are clearly distinct from the SSZ plutonic rocks (Fig. 14b). On the one hand, detailed petrological studies show that all these potassic rocks originated from mantle sources enriched by additional phases (see Castro et al., 2013; Kananian et al., 2014; Moritz et al., 2016; Ahmadian et al., 2016). As mentioned earlier, alkaline melt-mantle rock interaction could lead to the formation of phlogopite at lithospheric depths. Partial melting of such phlogopite-bearing mantle lithosphere can explain the high $\mathrm{K}_{2} \mathrm{O}$ and $\mathrm{SiO}_{2}$ contents of the potassic plutonic rocks (Fig. 11b). However, these rocks have very similar isotopic compositions to the more recent TK lavas. Thus, a heterogeneous source and, or, the mixing of a low $\mathrm{K}_{2} \mathrm{O}$ and high ${ }^{143} \mathrm{Nd} / 144 \mathrm{Nd}$ melt (e.g. sodicLK) with a high $\mathrm{K}_{2} \mathrm{O}$ and ${ }^{87} \mathrm{Sr} /{ }^{86} \mathrm{Sr}$ melt (e.g., UK or continental crust) may explain all the observed isotopic and alkali variations.

The potassic character also broadly appears in high-K I-type granitoids from 37 to $47 \mathrm{Ma}$ (Figs 14 and 13b). Experimental studies show that high-K I-type granitoids derive only from partial melting of hydrous, potassium-rich, meta-igneous rocks (Roberts \& Clemens, 1993), whereas I-type granitoids have a calc-alkaline affinity and originate from partial melting of older meta-igneous rocks in continental arc settings (Chappell \& Stephens, 1988). Because of their low $\mathrm{K}_{2} \mathrm{O}$ contents, metabasalts in all kinds of crustal metamorphic terranes are an unsuitable source for high-K I-type granitoids.

In summary, the volcanic rocks from the TIP older than $11 \mathrm{Ma}$ are essentially TK and sodic-LK in composition, with a minority of sodic-HK compositions. The young (less than 10-11 
Ma) HK and sodic-HK lavas are found to border low-density CP domains, while sodic-LK lavas are rather located immediately above $\mathrm{CP}$ domains. These correlations between lava chemistry and the development of CPs may also apply to volcanic rocks older than 11 Ma since: (i) they have comparable characteristics to younger lavas, and (ii) the long-standing history of subduction throughout the TIP supports a long-standing development of CPs from the MTZ. When considering the small number of old volcanic rocks available for study, it should be noted that old lavas erupted at the surface have a high probability to have been destroyed by surface erosion processes. Most of the remaining plutonic rocks therefore result either from the re-melting of metasomatized initially competent mantle lithosphere located above CPs or from CP-derived melts influenced by secondary processes at shallow depths (e.g. mixing or interaction with the crust). Our proposed scenario requires a critical overview of petrologic studies of the older magmatism. Particularly in the case of the TIP, extrapolation of our proposed interpretation of the young magmatism to older magmatism suggests an alternative general explanation of the alkaline fingerprints of magmatism in an orogenic context, without necessarily involving active subduction processes.

\section{CONCLUSIONS}

There is a consensus that subducting slabs play a major role in the transport of C-O-H bearing phases into the mantle wedge and down to the MTZ. Because of the positive buoyancy of such hydrated and carbonated mantle within the MTZ, diapirs may develop after some time and transport these elements back into the overlying olivine stability field, where melts produced by decompression melting of the mantle are volatile-rich. As these volatile-rich melts progressively form a connected network at extremely low concentrations, a compaction process initiates and 
leads to the formation of melt-rich pockets. They may constitute the $100 \mathrm{~km}$-size low velocity areas imaged by seismic tomography below the TIP, which we call CPs (Compaction Pockets). Actually, these structures likely correspond to "magmons" that have been modelled by geophysicists working on melt-mantle compaction processes, have been observed by field geologists in mantle outcrops (small-size CPs), but have never been identified until now in the present-day mantle by seismologists.

For values of mantle physical properties consistent with what we know from experimental petrology and rock mechanics, the model that we propose here satisfactorily reproduces the formation of such CPs of size $\sim 160 \mathrm{~km} \times 80 \mathrm{~km}$, if we consider that mantle viscosity is not sensitive to low amounts of inter-granular melt ( 1\% in volume) and if the volatile-rich melts themselves have a very low viscosity (allowing them to segregate easily from the matrix). In that framework, the dynamics of CPs require an upward obstruction to melt percolation, which would arise from the precipitation of hydrated/carbonated mineral phases accumulating at their leading head. When melt concentration progressively increases in the CPs, the weight of the connected melt column integrated over the height of the $\mathrm{CP}$ increases, and the driving effective pressure rises. Because of the large size of these CPs and the large density contrast between the volatilerich melts and the surrounding mantle, this effective pressure can reach a few $100 \mathrm{MPa}$, triggering melt extraction by dyking (cf, hydrofracturing).

Such a model may apply to any problem associated with the migration of volatile-rich melts, such as for instance in the mantle wedge above an active subduction zone. In the present study, we applied it to the migration of volatile-rich melts through the upper mantle below the TIP. Based on large-scale tomographic models and seismic reflection data, we propose that volatile-rich diapirs root at the top of the MTZ in an area about $600 \mathrm{~km}$ wide located between the 
Greater Caucasus and the Zagros-Bitlis Sutures. The analysis of tomographic models down to $300 \mathrm{~km}$ depth leads to the identification of various CPs underlying the Turkish-Iranian

lithosphere. According to our model, the development of these CPs starts with the precipitation of richterite between 8 and $6.5 \mathrm{GPa}$ at $\mathrm{T} \sim 1300^{\circ} \mathrm{C}$. Such conditions provide a strong constraint on mantle temperature below the TIP, i.e. $\sim 100^{\circ} \mathrm{C}$ lower than typical continental domains. Such a condition is consistent with long-lived subduction processes $(\sim 200 \mathrm{Myr})$, which likely cooled the upper mantle beneath the TIP and eventually maintained the thermal stability of the continental lithosphere over time.

Finally, we show that magmatic provinces throughout the TIP systematically occur above the edges of CPs where the lithosphere is in horizontal extension, or above the central domain of a lithosphere block that has been delaminated by a CP. Our model explains why the volcanic fields that outcrop at the border of the CPs display rare UK and sodic-HK, but frequent sodic-LK melts, which rise via three series of dyking events that developed at $\sim 240 \mathrm{~km}, \sim 195 \mathrm{~km}$ and $\sim 135$ $\mathrm{km}$ depth, respectively. In addition, the model explains the presence of UK melts with low $\mathrm{SiO}_{2}$ and extremely high $\mathrm{K}_{2} \mathrm{O}$ and trace element contents in an orogenic belt (e.g. lamproites). The occurrence of such uncommon mantle-derived melts, sourced from extremely depleted mantle that has been enriched via subducted sediments, has never been explained before by any realistic physical model.

Another consequence of our model is the ponding and the eventual solidification of the UK and sodic-HK and sodic-LK melts inside the competent lithosphere above CPs. Plutonic outcrops which give access to part of the magmatic activity of the TIP prior to $23 \mathrm{Ma}$, possibly result from the re-melting of the metasomatized competent lithosphere and, or, mixing between CP-derived melts. Such an explanation is very similar to previous interpretations of a mixed 
mantle source (e.g. metasomatized lithosphere and upwelling asthenosphere) to explain the compositions of older plutonic and volcanic rocks. The only difference is that the metasomatism of the lithosphere is not related to mantle wedge processes but to the development of CPs. As a result, the "volatile-rich Compaction Pocket" model represents a robust new concept to explain continental alkaline magmatism throughout orogenic belts.

\section{REFERENCES}

Ackerman, L., Špaček, P., Magna, T., Ulrych, J., Svojtka, M., Hegner, E. \& Balogh, K. (2013). Alkaline and carbonate-rich melt metasomatism and melting of subcontinental lithospheric mantle: evidence from mantle xenoliths, NE Bavaria, Bohemian Massif. Journal of Petrology 54, 2597-2633.

Adamia, S., Zakariadze, G., Chkhotua, T., Sadradze, N., Tsereteli, N., Chabukiani, A. \& Gventsdze, A. (2011). Geology of the Caucasus: a review. Turkish Journal of Earth Sciences 20, 489-544.

Adamia, S.A., Lordkipanidze, M.B. \& Zakariadze, G.S. (1977). Evolution of an active continental margin as exemplifi ed by the Alpine history of the Caucasus: Tectonophysics 40, 183-199.

Aftabi, A. \& Atapour, H. (2000). Regional Aspects of Shoshonitic Volcanism in Iran, Episodes 23, 119-125.

Agard, P., Omrani, J., Jolivet, L. \& Mouthereau, F. (2005). Convergence history across Zagros (Iran): constraints from collisional and earlier deformation. International Journal of Earth Sciences 94, 401-419.

Agard, P., Omrani, J., Jolivet, L., Whitechurch, H., Vrielynck, B., Spakman, W. \& Wortel, R. (2011). Zagros orogeny: a subduction-dominated process. Geological Magazine 148, 692725.

Aghazadeh, M., Castro, A., Omran, N. R., Emami, M. H., Moinvaziri, H. \& Badrzadeh, Z. (2010). The gabbro (shoshonitic)-monzonite-granodiorite association of Khankandi pluton, Alborz Mountains, NW Iran. Journal of Asian Earth Sciences 38, 199-219.

Aghazadeh, M., Prelević, D., Badrzadeh, Z., Braschi, E., van den Bogaard, P. \& Conticelli, S. (2015). Geochemistry, Sr-Nd-Pb isotopes and geochronology of amphibole-and mica- 
bearing lamprophyres in northwestern Iran: Implications for mantle wedge heterogeneity in a palaeo-subduction zone. Lithos 216, 352-369.

Ahmadian, J., Sarjoughian, F., Lentz, D., Esna-ashari, A., Murata, M. \& Ozawa, H. (2016). Eocene K-rich adakitic rocks in the Central Iran : Implications for evaluating its $\mathrm{Cu}-\mathrm{Au}$ Mo metallogenic potential. Ore Geology Reviews 72, 323-342.

Ahmadzadeh, G., Jahangiri, A., Lentz, D. \& Mojtahedi, M. (2010). Petrogenesis of PlioQuaternary post-collisional ultrapotassic volcanism in NW of Marand, NW Iran. Journal of Asian Earth Sciences 39, 37-50.

Aktuğ, B., Parmaksız, E., Kurt, M., Lenk, O., Kılıçoğlu, A., Gürdal, M. A. \& Özdemir, S. (2013). Deformation of Central Anatolia: GPS implications. Journal of Geodynamics 67, 78-96.

Alavi, M. (1991). Sedimentary and structural characteristics of the Paleo-Tethys remnants in northeastern Iran. Geological Society of America Bulletin 103, 983-992.

Alavi, M. (1994). Tectonics of Zagros Orogenic belt of Iran, new data and interpretation. Tectonophys 229, 211-238.

Alinaghi, A., Koulakov, I. \& Thybo, H. (2007). Seismic tomographic imaging of P - and S waves velocity perturbations in the upper mantle beneath Iran, Geophysical Journal International 169, 1089-1102.

Allen, M. B., Kheirkhah, M., Neill, I., Emami, M. H. \& McLeod, C. L. (2013). Generation of arc and within-plate chemical signatures in collision zone magmatism: Quaternary lavas from Kurdistan Province, Iran. Journal of Petrology 54, 887-911.

Amidi, S.M., Emami, M.H. \& Michel, R. (1984). Alkaline character of Eocene volcanism in the middle part of Iran and its geodynamic situation. Geologische Rundschau 73, 917-932.

Ammannati, E., Jacob, D. E., Avanzinelli, R., Foley, S. F., \& Conticelli, S. (2016). Low Ni olivine in silica-undersaturated ultrapotassic igneous rocks as evidence for carbonate metasomatism in the mantle. Earth and Planetary Science Letters 444, 64-74.

Angel, R. J., Frost, D. J., Ross, N. L., \& Hemley, R. (2001). Stabilities and equations of state of dense hydrous magnesium silicates. Physics of the Earth and Planetary Interiors, 127, 181-196.

Aoki, K. I. (1975). Origin of phlogopite and potassic richterite bearing peridotite xenoliths from South Africa. Contributions to Mineralogy and Petrology 53, 145-156.

Arjmandzadeh, R., Karimpour, M. H., Mazaheri, S. A., Santos, J. F., Medina, J. M. \& Homam, S. M. (2011). Two-sided asymmetric subduction; implications for tectonomagmatic and metallogenic evolution of the Lut Block, eastern Iran. Journal of Asian Earth Sciences 41, 283-296. 
Asiabanha, A. \& Foden, J. (2012). Post-collisional transition from an extensional volcanosedimentary basin to a continental arc in the Alborz Ranges, N-Iran. Lithos 148, 98-111.

Austermann, J. \& Iaffaldano, G. (2013). The role of the Zagros orogeny in slowing down Arabia-Eurasia convergence since $\sim 5$ Ma. Tectonics 32, 351-363.

Avanzinelli, R., Lustrino, M., Mattei, M., Melluso, L. \& Conticelli, S. (2009). Potassic and ultrapotassic magmatism in the circum-Tyrrhenian region: significance of carbonated pelitic vs. pelitic sediment recycling at destructive plate margins. Lithos 113, 213-227.

Aydin, F., Karsli, O. \& Chen, B. (2008). Petrogenesis of the Neogene alkaline volcanics with implications for post-collisional lithospheric thinning of the Eastern Pontides, NE Turkey. Lithos 104, 249-266.

Aydin, F., Schmitt, A. K., Siebel, W., Sönmez, M., Ersoy, Y., Lermi, A. \& Duncan, R. (2014). Quaternary bimodal volcanism in the Niğde Volcanic Complex (Cappadocia, central Anatolia, Turkey): age, petrogenesis and geodynamic implications. Contributions to Mineralogy and Petrology 168, 1078.

Azizi, H., Asahara, Y. \& Tsuboi, M. (2014). Chemie der Erde The role of heterogenetic mantle in the genesis of adakites northeast of Sanandaj , northwestern Iran. Chemie Der Erde Geochemistry 74, 87-97.

Barth, M. G., McDonough, W. F. \& Rudnick, R. L. (2000). Tracking the budget of Nb and Ta in the continental crust. Chemical Geology 165, 197-213.

Becker, M., \& Roex, A. P. L. (2006). Geochemistry of South African on-and off-craton, Group I and Group II kimberlites: petrogenesis and source region evolution. Journal of Petrology 47, 673-703.

Berberian, F. \& Berberian, M. (1981). Tectono-plutonic episodes in Iran. Zagros Hindu Kush Himalaya Geodynamic Evolution, American Geophysical Union \& Geological Society of America, Washington, 5-32.

Berberian, M. \& King, G. C. P. (1981). Towards a paleogeography and tectonic evolution of Iran. Canadian journal of earth sciences 18, 210-265.

Beydokhti, R. M., Karimpour, M. H., Mazaheri, S. A., Santos, J. F. \& Klötzli, U. (2015). U-Pb zircon geochronology, Sr-Nd geochemistry, petrogenesis and tectonic setting of Mahoor granitoid rocks (Lut Block, Eastern Iran). Journal of Asian Earth Sciences 111, 192-205.

Bonadiman, C., Beccaluva, L., Coltorti, M. \& Siena, F. (2005). Kimberlite-like metasomatism and 'garnet signature'in spinel-peridotite xenoliths from Sal, Cape Verde Archipelago: relics of a subcontinental mantle domain within the Atlantic oceanic lithosphere?. Journal of Petrology 46, 2465-2493. 
Bonin, B. (1998). Alkali-calcic and alkaline post-orogenic (PO) granite magmatism : petrologic constraints and geodynamic settings. Lithos 45, 45-70.

Boztuğ, D., Harlavan, Y., Arehart, G. B., Satır, M. \& Avcı, N. (2007). K-Ar age, whole-rock and isotope geochemistry of A-type granitoids in the Divriği-Sivas region, eastern-central Anatolia, Turkey. Lithos 97, 193-218.

Boztuğ, D., Jonckheere, R.C. (2007). Apatite fission-track data from central- Anatolian granitoids (Turkey): constraints on Neo-Tethyan closure. Tectonics 26, TC3011. doi:10.1029/2006TC001988.

Brey, G. P., Bulatov, V. K. \& Girnis, A. V. (2011). Melting of K-rich carbonated peridotite at 6 $10 \mathrm{GPa}$ and the stability of K-phases in the upper mantle. Chemical Geology 281, 333-342.

Brey, G. P., Bulatov, V. K., Girnis, A. V. \& Lahaye, Y. (2008). Experimental melting of carbonated peridotite at 6-10 GPa. Journal of Petrology 49, 797-821.

Burnham, A. D., Thomson, A. R., Bulanova, G. P., Kohn, S. C., Smith, C. B., \& Walter, M. J. (2015). Stable isotope evidence for crustal recycling as recorded by superdeep diamonds. Earth and Planetary Science Letters 432, 374-380.

Burov, E. B., \& A. B. Watts. (2006). The long-term strength of continental lithosphere:" jelly sandwich" or" crème brûlée"?. GSA today 16 1, 1- 4.

Burov, E. B., \& Diament, M. (1995). The effective elastic thickness (Te) of continental lithosphere: what does it really mean?. Journal of Geophysical Research: Solid Earth 100(B3), 3905-3927.

Cai, Z. \& Bercovici, D. (2016). Two-dimensional magmons with damage and the transition to magma-fracturing. Physics of the Earth and Planetary Interiors 256, 13-25.

Canil, D. \& Scarfe, C. M. (1990). Phase relations in peridotite p CO2 systems to 12 GPa: implication for the origin of kimberlite and carbonate stability in the Earth's mantle. Journal of Geophysical Research 95, 15805-15816.

Carpenter, R. L., Edgar, A. D. \& Thibault, Y. (2002). Origin of spongy textures in clinopyroxene and spinel from mantle xenoliths, Hessian Depression, Germany. Mineralogy and Petrology 74, 149-162.

Castro, A., Aghazadeh,M., Badrzadeh, Z. \& Chichorro,M. (2013). Late Eocene-Oligocene postcollisionalmonzonitic intrusions fromthe Alborz magmatic belt, NWIran. An exam- ple of monzonite magma generation from a metasomatized mantle source. Lithos 180-181, 109127.

Chappell, B. W., \& Stephens, W. E. (1988). Origin of infracrustal (I-type) granite magmas. Earth and Environmental Science Transactions of The Royal Society of Edinburgh 79, 71-86. 
Coltorti, M. \& Grégoire, M. (2008). Metasomatism in oceanic and continental lithospheric mantle: introduction. Geological Society, London, Special Publications 293, 352.

Conceição, R. V. \& Green, D. H. (2004). Derivation of potassic (shoshonitic) magmas by decompression melting of phlogopite+ pargasite lherzolite. Lithos 72, 209-229.

Condamine, P. \& Médard, E. (2014). Experimental melting of phlogopite-bearing mantle at 1 GPa: Implications for potassic magmatism. Earth and Planetary Science Letters 397, 80-92.

Condamine, P., Médard, E. \& Devidal, J.-L. (2016). Experimental melting of phlogopiteperidotite in the garnet stability field. Contributions to Mineralogy and Petrology 171, 95.

Dalton, J. A. \& Presnall, D. C. (1998). The continuum of primary carbonatitic-kimberlitic melt compositions in equilibrium with lherzolite: data from the system $\mathrm{CaO}-\mathrm{MgO}-\mathrm{Al} 2 \mathrm{O} 3-\mathrm{SiO} 2-$ CO2 at 6 GPa. Journal of Petrology 39, 1953-1964.

Dargahi, S., Arvin, M., Pan, Y. \& Babaei, A. (2010). Lithos Petrogenesis of post-collisional Atype granitoids from the Urumieh - Dokhtar magmatic assemblage, Southwestern Kerman , Iran : Constraints on the Arabian - Eurasian continental collision. Lithos 115, 190-204.

Dasgupta, R., \& Hirschmann, M. M. (2006). Melting in the Earth's deep upper mantle caused by carbon dioxide. Nature 440, 659.

Davidson, J., Hassanzadeh, J., Berzins, R., Stockli, D. F., Bashukooh, B., Turrin, B. \& Pandamouz, A. (2004). The geology of the Damavand volcano, Alborz Mountains, northern Iran, Geological Society of America Bulletin 116, 16-29.

Davis, F. A., Hirschmann, M. M. \& Humayun, M. (2011). The composition of the incipient partial melt of garnet peridotite at $3 \mathrm{GPa}$ and the origin of OIB. Earth and Planetary Science Letters 308, 380-390.

Deevsalar, R., Shinjo, R., Ghaderi, M., Murata, M., Hoskin, P. W. O., Oshiro, S. \& Neill, I. (2017). Mesozoic-Cenozoic mafic magmatism in Sanandaj-Sirjan Zone, Zagros Orogen (Western Iran): Geochemical and isotopic inferences from Middle Jurassic and Late Eocene gabbros. Lithos 284, 588-607.

Demouchy, S., Deloule, E., Frost, D. J. \& Keppler, H. (2005). Pressure and temperaturedependence of water solubility in Fe-free wadsleyite. American Mineralogist 90, 1084-1091.

Doroozi, R., Vaccaro, C., Masoudi, F. \& Petrini, R. (2016). Cretaceous alkaline volcanism in south Marzanabad, northern central Alborz, Iran: Geochemistry and petrogenesis. Geoscience Frontiers 7, 937-951.

Dupuy, C., Liotard, J. M. \& Dostal, J. (1992). Zr/Hf fractionation in intraplate basaltic rocks: carbonate metasomatism in the mantle source. Geochimica et Cosmochimica Acta 56, 24172423. 
Eby, G. N. (1990). The A-type granitoids: a review of their occurrence and chemical characteristics and speculations on their petrogenesis. Lithos 26, 115-134.

Eby, G. N. (1992). Chemical subdivision of the A-type granitoids: petrogenetic and tectonic implications. Geology 20, 641-644.

Edgar, A. D., \& Vukadinovic, D. (1993). Potassium-rich clinopyroxene in the mantle: An experimental investigation of a K-rich lamproite up to $60 \mathrm{kbar}$. Geochimica et Cosmochimica Acta 57, 5063-5072.

Eggler, D. H. (1989). Kimberlites: How do they form?. In Kimberlites and Related Rocks (ed. J. Ross) Blackwell 1, 489-504.

Ekici, T., Macpherson, C. G., Otlu, N. \& Fontignie, D. (2014). Foreland magmatism during the Arabia-Eurasia collision: Pliocene-Quaternary activity of the Karacadağ Volcanic Complex, SW Turkey. Journal of Petrology 55, 1753-1777.

Enggist, A., Chu, L. \& Luth, R. W. (2012). Phase relations of phlogopite with magnesite from 4 to $8 \mathrm{GPa}$. Contributions to Mineralogy and Petrology 163, 467-481.

Esmaeily, D. (2005). Petrology of the Jurassic Shah-Kuh granite (eastern Iran), with reference to tin mineralization. Journal of Asian Earth Sciences 25, 961-980.

Eyuboglu, Y., Santosh,M., Yi, K., Bektaş, O. \& Kwon, S. (2012). Discovery of Miocene adakitic dacite from the Eastern Pontides Belt and revised geodynamic model for the late Cenozoic evolution of the Eastern Mediterranean region. Lithos 146-147, 218-232.

Faccenna, C., le, T. W., Auer, L., Billi, A., Boschi, L., Brun, J. P. \& Piromallo, C. (2014). Mantle dynamics in the Mediterranean. Reviews of Geophysics 52, 283-332.

Faul, U. H. (1997). Permeability of partially molten upper mantle rocks from experiments and percolation theory. Journal of Geophysical Research 102, 10299-10311.

Fichtner, A., Saygin, E., Taymaz, T., Cupillard, P., Capdeville, Y. \& Trampert, J. (2013). The deep structure of the North Anatolian fault zone. Earth and Planetary Science Letters 373, 109-117.

Fitton, J.G. \& Upton, B.G.J. (1987). Alkaline igneous rocks. Geological Society, London, Special Publications 30, 544.

Foley, S. F. (1994). Geochemical and experimental studies of the origin of ultrapotassic igneous rocks. Neues Jahrbuch fur Mineralogie, Abhandlungen 167, 1-55.

Förster, M. W., Prelević, D., Schmück, H. R., Buhre, S., Veter, M., Mertz-Kraus, R., \& Jacob, D. E. (2016). Melting and dynamic metasomatism of mixed harzburgite+ glimmerite mantle 
source: Implications for the genesis of orogenic potassic magmas. Chemical Geology $\mathbf{4 5 5}$, 182-191.

Francois T., Burov, E., Agard, P. \& Meyer, B. (2014). Buildup of a dynamically supported orogenic plateau: Numerical modeling of the Zagros/Central Iran case study Geochemistry, Geophysics, Geosystems 15, 1632-2654.

Frezzotti, M. L. \& Touret, J. L. (2014). CO 2, carbonate-rich melts, and brines in the mantle. Geoscience Frontiers 5, 697-710.

Fukao,Y.,Widiyantoro, S. \& Obayashi, M. (2001). Stagnant slabs in the upper and lower mantle transition region. Reviews of Geophysics 39, 291-324.

Fumagalli, P., Zanchetta, S. \& Poli, S. (2009). Alkali in phlogopite and amphibole and their effects on phase relations in metasomatized peridotites: A high-pressure study. Contributions to Mineralogy and Petrology 158, 723-737.

Gerbault, M., Fontaine, F. J., Rabinowicz, M., \& Bystricky, M. (2017). Elastic flexure controls magma trajectories and explains the offset of primary volcanic activity upstream of mantle plume axis at la Réunion and Hawaii hotspot islands. Earth and Planetary Science Letters 462, 142-156.

Ghalamghash, J., Mousavi, S. Z., Hassanzadeh, J. \& Schmitt, A. K. (2016). Geology, zircon geochronology, and petrogenesis of Sabalan volcano (northwestern Iran). Journal of Volcanology and Geothermal Research 327, 192-207.

Ghasemi, A. \& Talbot, C.J. (2006). A new tectonic scenario from the Sanandaj-Sirjan Zone (Iran). Journal of Asian Earth Sciences 26, 683-693.

Ghorbani, M. R. \& Bezenjani, R. N. (2011). Slab partial melts from the metasomatizing agent to adakite, Tafresh Eocene volcanic rocks, Iran. Island Arc 20, 188-202.

Ghorbani, M. R., Graham, I. T. \& Ghaderi, M. (2014). Oligocene-Miocene geodynamic evolution of the central part of Urumieh-Dokhtar Arc of Iran. International Geology Review 56, 10391050 .

Ghosh, S., Litasov, K. \& Ohtani, E. (2014). Phase relations and melting of carbonated peridotite between 10 and $20 \mathrm{GPa}$ : A proxy for alkali- and CO2-rich silicate melts in the deep mantle. Contributions to Mineralogy and Petrology 167, 1-23.

Ghosh, S., Ohtani, E., Litasov, K. D. \& Terasaki, H. (2009). Solidus of carbonated peridotite from 10 to $20 \mathrm{GPa}$ and origin of magnesiocarbonatite melt in the Earth's deep mantle. Chemical Geology 262, 17-28.

Girnis, A. V., Bulatov, V. K. \& Brey, G. P. (2011). Formation of primary kimberlite meltsConstraints from experiments at 6-12GPa and variable CO 2/H 2 O. Lithos 127, 401-413. 
Göğüş, O. H., Pysklywec, R. N., Şengör, A. M. C., \& Gün, E. (2017). Drip tectonics and the enigmatic uplift of the Central Anatolian Plateau. Nature communications 8, 1538.

Gögüs, O.H., Pysklywec, R.N., Corbi, F. \& Faccenna, C. (2011). The surface tectonics of mantle lithosphere delamination following ocean lithosphere subduction: insights from physical-scaled analogue experiments. Geochemistry, Geophysics, Geosystems 12 , Q05004. http://dx.doi.org/10.1029/2010GC003430.

Grant, T. B., Milke, R. \& Wunder, B. (2014). Experimental reactions between olivine and orthopyroxene with phonolite melt: implications for the origins of hydrous amphibole+ phlogopite+ diopside bearing metasomatic veins. Contributions to Mineralogy and Petrology 168, 1073.

Grassi, D., Schmidt, M. W. \& Günther, D. (2012). Element partitioning during carbonated pelite melting at 8,13 and $22 \mathrm{GPa}$ and the sediment signature in the EM mantle components. Earth and Planetary Science Letters 327-328, 84-96.

Green, D. H. (2015). Experimental petrology of peridotites, including effects of water and carbon on melting in the Earth's upper mantle. Physics and Chemistry of Minerals 42, 95-122.

Green, T. H. \& Pearson, N. J. (1987). An experimental study of Nb and Ta partitioning between Ti-rich minerals and silicate liquids at high pressure and temperature. Geochimica et Cosmochimica Acta 51, 55-62.

Green, T. H. (1995). Significance of $\mathrm{Nb} / \mathrm{Ta}$ as an indicator of geochemical processes in the crustmantle system. Chemical Geology 120, 347-359.

Grégoire, M., Bell, D. R. \& Le Roex, A. P. (2003). Garnet lherzolites from the Kaapvaal Craton (South Africa): trace element evidence for a metasomatic history. Journal of Petrology 44, 629-657.

Grégoire, M., Rabinowicz, M. \& Janse, A. J. A. (2006). Mantle mush compaction: A key to understand the mechanisms of concentration of kimberlite melts and initiation of swarms of kimberlite dykes. Journal of Petrology 47, 631-646.

Hacker, B. R., \& Abers, G. A. (2004). Subduction Factory 3: An Excel worksheet and macro for calculating the densities, seismic wave speeds, and $\mathrm{H} 2 \mathrm{O}$ contents of minerals and rocks at pressure and temperature. Geochemistry, Geophysics, Geosystems 5. doi:10.1029/2003GC000614.

Haghipour, A., Saidi, A., Aganabati, A., Moosavi, A., Mohebi, A., Sadeghi, M. \& Zarei, M. (2009). International Geological Map of the Middle East. Commission for the Geological Map of the World (Subcommission for the Middle East). 
Hammond, W. C. \& Humphreys, E. D. (2000). Upper mantle seismic wave velocity: Effects of realistic partial melt geometries. Journal of Geophysical Research: Solid Earth 105(B5), 10975-10986.

Hassanzadeh, J. \& Wernicke, B. P. (2016). The Neotethyan Sanandaj-Sirjan zone of Iran as an archetype for passive margin-arc transitions. Tectonics 35, 586-621.

Hawkesworth, C. J., Gallagher, K., Hergt, J. M. \& McDermott, F. (1993). Mantle and slab contributions in arc magmas. Annual Review of Earth and Planetary Sciences 21, 175-204.

Hawkesworth, C., Turner, S., Gallagher, K., Hunter, A., Bradshaw, T. \& Rogers, N. (1995). Calc-alkaline magmatism, lithospheric thinning and extension in the Basin and Range. Journal of Geophysical Research Solid Earth 100(B6), 10271-10286.

Herzberg, C., Raterron, P. \& Zhang, J. (2000). New experimental observations on the anhydrous solidus for peridotite KLB-1. Geochemistry, Geophysics, Geosystems 1. doi:10.1029/2000GC000089

Hirschmann, M. M. (2006). Water, melting, and the deep Earth H2O cycle. Annual Review of Earth and Planetary Sciences. 34, 629-653.

Hirschmann, M. M. (2010). Partial melt in the oceanic low velocity zone. Physics of the Earth and Planetary Interiors 179, 60-71.

Hirschmann, M. M., Kogiso, T., Baker, M. B. \& Stolper, E. M. (2003). Alkalic magmas generated by partial melting of garnet pyroxenite. Geology 31, 481-484.

Hole, M. J., Saunders, A. D., Rogers, G. \& Sykes, M. A. (1994). The relationship between alkaline magmatism, lithospheric extension and slab window formation along continental destructive plate margins. Geological Society, London, Special Publications 81, 265-285.

Hooper, P. R., Bailey, D. G. \& Holder, G. A. (1995). Tertiary calc-alkaline magmatism associated with lithospheric extension in the Pacific Northwest. Journal of Geophysical Research: Solid Earth 100(B6), 10303-10319.

Houseman, G. A. \& Molnar, P. (1997). Gravitational (Rayleigh-Taylor) instability of a layer with non-linear viscosity and convective thinning of continental lithosphere. Geophysical Journal International 128, 125-150.

Ionov, D. A. \&Hofmann, A. W. (1995). Nb-Ta-rich mantle amphiboles and micas: implications for subduction-related metasomatic trace element fractionation. Earth and Planetary Science Letters 131, 341-356.

Ionov, D. A., Bodinier, J. L., Mukasa, S. B. \& Zanetti, A. (2002). Mechanisms and sources of mantle metasomatism: major and trace element conditions of peridotite xenoliths from Spitzbergen in the context of numerical modelling. Journal of Petrology 43, 2219-2259. 
Ionov, D. A., Dupuy, C., O'Reilly, S. Y., Kopylova, M. G. \& Genshaft, Y. S. (1993). Carbonated peridotite xenoliths from Spitsbergen: implications for trace element signature of mantle carbonate metasomatism. Earth and Planetary Science Letters, 119, 283-297.

Irvine, T. N. J. \& Baragar, W. R. A. F. (1971). A guide to the chemical classification of the common volcanic rocks. Canadian journal of earth sciences 8, 523-548.

Jahangiri, A. (2007). Post-collisional Miocene adakitic volcanism in NW Iran : Geochemical and geodynamic implications, Journal of Asian Earth Sciences 30, 433-447.

Jolivet, L., Faccenna, C., Huet, B., Labrousse, L., Le Pourhiet, L., Lacombe, O. \& Philippon, M. (2013). Aegean tectonics: Strain localisation, slab tearing and trench retreat. Tectonophysics 597, 1-33.

Kaban, M. K., El Khrepy, S., Al-Arifi, N., Tesauro, M. \& Stolk, W. (2016). Three-dimensional density model of the upper mantle in the Middle East: Interaction of diverse tectonic processes. Journal of Geophysical Research: Solid Earth 121, 5349-5364.

Kaislaniemi, L., Van Hunen, J., Allen, M. B. \& Neill, I. (2014). Sublithospheric small-scale convection — a mechanism for collision zone magmatism. Geology 42, 291-294.

Kananian, A., Sarjoughian, F., Nadimi, A., Ahmadian, J. \& Ling, W. (2014). Geochemical characteristics of the Kuh-e Dom intrusion, Urumieh-Dokhtar Magmatic Arc (Iran): Implications for source regions and magmatic evolution. Journal of Asian Earth Sciences 90, 137-148.

Karato, S. I. \& Wu, P. (1993). Rheology of the upper mantle: a synthesis. Science 260, 771-778.

Karato, S.I. (2011). Water distribution across the mantle transition zone and its implications for global material circulation. Earth and Planetary Science Letters 301, 413-423.

Kargaranbafghi, F. \& Neubauer, F. (2015). Lithospheric thinning associated with formation of a metamorphic core complex and subsequent formation of the Iranian plateau. GSA Today 25, 4-8.

Karsli, O., Caran, Ş., Dokuz, A., Çoban, H., Chen, B. \& Kandemir, R. (2012a). A-type granitoids from the Eastern Pontides, NE Turkey: records for generation of hybrid A-type rocks in a subduction-related environment. Tectonophysics 530, 208-224.

Karsli, O., Dokuz, A., Uysal, İ., Aydin, F., Kandemir, R. \& Wijbrans, J. (2010). Generation of the Early Cenozoic adakitic volcanism by partial melting of mafic lower crust, Eastern Turkey: implications for crustal thickening to delamination. Lithos 114, 109-120.

Karsli, O., Dokuz, A., Uysal, Ý., Ketenci, M., Chen, B. \& Kandemir, R. (2012b). Deciphering the shoshonitic monzonites with I-type characteristic, the Sisdaği pluton, NE Turkey: magmatic response to continental lithospheric thinning. Journal of Asian Earth Sciences 51, 45-62. 
Karsli, O., Ketenci, M., Uysal, İ., Dokuz, A., Aydin, F., Chen, B. \& Wijbrans, J. (2011). Adakitelike granitoid porphyries in the Eastern Pontides, NE Turkey: potential parental melts and geodynamic implications. Lithos 127, 354-372.

Katsura, T., Yoneda, A., Yamazaki, D., Yoshino, T. \& Ito, E. (2010). Adiabatic temperature profile in the mantle. Physics of the Earth and Planetary Interiors 183, 212-218.

Kavanagh, J. L. \& Sparks, R. S. J. (2009). Temperature changes in ascending kimberlite magma. Earth and Planetary Science Letters 286, 404-413.

Kelemen, P. B., Hirth, G., Shimizu, N., Spiegelman, M. \& Dick, H. J. (1997). A review of melt migration processes in the adiabatically upwelling mantle beneath oceanic spreading ridges. Philosophical Transactions of the Royal Society of London A: Mathematical, Physical and Engineering Sciences 355, 283-318.

Keller, T., \& Katz, R. F. (2016). The Role of Volatiles in Reactive Melt Transport in the Asthenosphere, Journal of Petrology 57, 1073-1108.

Keller, T., May, D.A. \& Kaus, B.J. (2013). Numerical modelling of magma dynamics coupled to tectonic deformation of lithosphere and crust. Geophysical Journal International 195, 14061442.

Keshav, S. \& Gudfinnsson, G. H. (2010). Experimentally dictated stability of carbonated oceanic crust to moderately great depths in the Earth: Results from the solidus determination in the system $\mathrm{CaO}-\mathrm{MgO}-\mathrm{Al} 2 \mathrm{O} 3-\mathrm{SiO} 2-\mathrm{CO} 2$. Journal of Geophysical Research: Solid Earth 115, B05205, doi:10.1029/2009JB006457.

Keskin, M. (2003). Magma generation by slab steepening and breakoff beneath a subduction-accretion complex: An alternative model for collision-related volcanism in Eastern Anatolia, Turkey. Geophysical Research Letters 30. doi.org/10.1029/2003GL018019

Keskin, M., Genç, Ş. C. \& Tüysüz, O. (2008). Petrology and geochemistry of post-collisional Middle Eocene volcanic units in North-Central Turkey: evidence for magma generation by slab breakoff following the closure of the Northern Neotethys Ocean. Lithos 104, 267-305.

Keskin, M., Kurtoglu, S., Kendirci, M., Atabek, M. E., \& Yazici, C. (2005). Homeostasis model assessment is more reliable than the fasting glucose/insulin ratio and quantitative insulin sensitivity check index for assessing insulin resistance among obese children and adolescents. Pediatrics 115, 500-503.

Khalaji, A. A., Esmaeily, D., Valizadeh, M. V. \& Rahimpour-Bonab, H. (2007). Petrology and geochemistry of the granitoid complex of Boroujerd, Sanandaj-Sirjan Zone, Western Iran. Journal of Asian Earth Sciences 29, 859-877. 
Khalatbari Jafari, M., Babaie, H. A. \& Moslempour, M. E. (2016). Mid-ocean-ridge to suprasubduction geochemical transition in the hypabyssal and extrusive sequences of major Upper Cretaceous ophiolites of Iran. Geological Society of America Special Papers 525, SPE525-07.

Kheirkhah, M., Neill, I. \& Allen, M. B. (2015). Petrogenesis of OIB-like basaltic volcanic rocks in a continental collision zone: Late Cenozoic magmatism of Eastern Iran. Journal of Asian Earth Sciences 106, 19-33.

Kheirkhah, M., Neill, I., Allen, M. B., \& Ajdari, K. (2013). Small-volume melts of lithospheric mantle during continental collision: Late Cenozoic lavas of Mahabad, NW Iran. Journal of Asian Earth Sciences 74, 37-49.

Khezerlou, A. A., Amel, N., Gregoire, M., Moayyed, M. \& Jahangiri, A. (2017). Geochemistry and mineral chemistry of pyroxenite xenoliths and host volcanic alkaline rocks from north west of Marand (NW Iran). Mineralogy and Petrology doi, 10.1007/s00710-017-0502-6.

Kind, R., Eken, T., Tilmann, F., Sodoudi, F., Taymaz, T., Bulut, F. \& Schneider, F. (2015). Thickness of the lithosphere beneath Turkey and surroundings from S-receiver functions. Solid Earth 6, 971.

Konzett, J. \& Ulmer, P. (1999). The stability of hydrous potassic phases in lherzolitic mantle-an experimental study to $9.5 \mathrm{GPa}$ in simplified and natural bulk compositions. Journal of Petrology 40, 629-652.

Konzett, J., \& Fei, Y. (2000). Transport and storage of potassium in the Earth's upper mantle and transition zone: an experimental study to $23 \mathrm{GPa}$ in simplified and natural bulk compositions. Journal of Petrology 41, 583-603.

Konzett, J., Sweeney, R.J., Thompson, A.B. \& Ulmer, P. (1997). Potassium amphibole stability in the upper mantle: an experimental study in a peralkaline KNCMASH system to $8.5 \mathrm{GPa}$. Journal of Petrology 38, 537-568.

Köprübasi, N. \& Kirmaci, M. Z. (2014). Chemie der Erde Mineral chemical constraints on the petrogenesis of mafic and $\mathrm{g}$ volcanoes, intermediate volcanic rocks from the Erciyes and Hasanda ` Central Turkey, Chemie der Erde 74, 585-600.

Koulakov, I. Y., Kukarina, E. V., Gordeev, E. I., Chebrov, V. N., \& Vernikovsky, V. A. (2016). Magma sources in the mantle wedge beneath the volcanoes of the Klyuchevskoy group and Kizimen based on seismic tomography modeling. Russian Geology and Geophysics 57, 82-94.

Koulakov, I., Zabelina, I., Amanatashvili, I. \& Meskhia, V. (2012). Nature of orogenesis and volcanism in the Caucasus region based on results of regional tomography. Solid Earth, $\mathbf{3}$, 327. 
Kuritani, T., Kimura, J. I., Ohtani, E., Miyamoto, H. \& Furuyama, K. (2013). Transition zone origin of potassic basalts from Wudalianchi volcano, northeast China. Lithos 156, 1-12.

Le Bas, M. J., Maitre, R. W., Streckeisen, A. \& Zanettin, B. (1986). A chemical classification of volcanic rocks based on the total alkali-silica diagram. Journal of Petrology 27, 745-750.

Lebedev, V. A., Chernyshev, I. V., Dudauri, O. Z., Arakelyants, M. M., Bairova, E. D., Gol tsman, Y. V. \& Vashakidze, G. T. (2003). The Samsari volcanic center as an example of recent volcanism in the Lesser Caucasus: K-Ar geochronological and $\mathrm{Sr}-\mathrm{Nd}$ isotopic data. In Doklady Earth Sciences, Akademiia Nauk, Interpreiodica publishing 393, 1323-1328.

Liotard, J.M., Dautria, J.M., Bisch, D., Condomines, J., Mehdizadeh, H. \& Ritz, J.F. (2008). Origin of the absarokite-banakite association of the Damavand volcano (Iran): trace elements and $\mathrm{Sr}, \mathrm{Nd}, \mathrm{Pb}$ isotope constraints. International Journal of Earth Sciences 97, 89102.

Litasov, K. D., Shatskiy, A. F., Pal'yanov, Y. N., Sokol, A. G., Katsura, T. \& Ohtani, E. (2009). Hydrogen incorporation into forsterite in $\mathrm{Mg}_{2} \mathrm{SiO}_{4}-\mathrm{K}_{2} \mathrm{Mg}\left(\mathrm{CO}_{3}\right)_{2}-\mathrm{H}_{2} \mathrm{O}$ and $\mathrm{Mg}_{2} \mathrm{SiO}_{4-}$ $\mathrm{H}_{2} \mathrm{O}-\mathrm{C}$ at 7.5-14.0 GPa. Russian Geology and Geophysics 50, 1129-1138.

Litasov, K. D., Shatskiy, A. N. T. O. N. \& Ohtani, E. (2013). Earth's mantle melting in the presence of C-O-H-bearing fluid. Physics and Chemistry of the Deep Earth, no number, 3865.

Litasov, K. \& Ohtani, E. (2002). Phase relations and melt compositions in CMAS-pyrolite-H2O system up to $25 \mathrm{GPa}$. Physics of the Earth and Planetary Interiors 134, 105-127.

Lustrino, M. \& Wilson, M. (2007). The circum-Mediterranean anorogenic Cenozoic igneous province. Earth-Science Reviews 81, 1-65.

Lustrino, M., Duggen, S. \& Rosenberg, C. L. (2011). The Central-Western Mediterranean: anomalous igneous activity in an anomalous collisional tectonic setting. Earth-Science Reviews 104, 1-40.

Lustrino, M., Keskin, M., Mattioli, M., Lebedev, V. A., Chugaev, A., Sharkov, E. \& Kavak, O. (2010). Early activity of the largest Cenozoic shield volcano in the circum-Mediterranean area: Mt. Karacadağ, SE Turkey. European Journal of Mineralogy 22, 343-362.

Maaløe, S. \& Scheie, S. M. (1982). The permeability controlled accumulation of primary magma. Contributions to Mineralogy and Petrology 81, 350-357.

Mallik, A., \& Dasgupta, R. (2014). Effect of variable CO2 on eclogite-derived andesite and lherzolite reaction at $3 \mathrm{GPa}$-Implications for mantle source characteristics of alkalic ocean island basalts. Geochemistry, Geophysics, Geosystems 15, 1533-1557. 
Masson, F., Lehujeur, M., Ziegler, Y. \& Doubre, C. (2014). Strain rate tensor in Iran from a new GPS velocity field. Geophysical Journal International, 197, 10-21.

McDonough, W. F. (1990). Constraints on the composition of the continental lithospheric mantle. Earth and Planetary Science Letters 101, 1-18.

McKenzie, D. (1984). The generation and compaction of partially molten rock. Journal of Petrology 25, 713-765.

McKenzie, D. \& Priestley, K. (2016). Speculations on the formation of cratons and cratonic basins. Earth and Planetary Science Letters 435, 94-104.

McQuarrie, N., Stock, J. M., Verdel, C. \& Wernicke, B. P. (2003). Cenozoic evolution of Neotethys and implications for the causes of plate motions, Geophysical Research Letters 30, 30-33.

Mei, S., Bai, W., Hiraga, T. \& Kohlstedt, D. L. (2002). Influence of melt on the creep behavior of olivine-basalt aggregates under hydrous conditions. Earth and Planetary Science Letters, 201, 491-507.

Minarik, W. G. \& Watson, E. B. (1995). Interconnectivity of carbonate melt at low melt fraction. Earth and Planetary Science Letters 133, 423-437.

Mirnejad, H., Hassanzadeh, J., Cousens, B. L. \& Taylor, B. E. (2010). Geochemical evidence for deep mantle melting and lithospheric delamination as the origin of the inland Damavand volcanic rocks of northern Iran. Journal of Volcanology and Geothermal Research 198, 288296.

Mitchell, R. H. \& Bergman, S. C. (1991). Petrology of lamproites. New York: Plenum, 295-35.

Mitchell, R. H. (2004). Experimental studies at 5-12 GPa of the Ondermatjie hypabyssal kimberlite. Lithos 76, 551-564.

Mohammadi, E., Sodoudi, F., Kind, R. \& Rezapour, M. (2013). Tectonophysics Presence of a layered lithosphere beneath the Zagros collision zone. Tectonophysics 608, 366-375.

Monnereau, M. \& Rabinowicz, M. (1996). Is the $670 \mathrm{~km}$ phase transition able to layer the Earth's convection in a mantle with depth-dependent viscosity?. Geophysical research letters $\mathbf{2 3}$, 1001-1004.

Morgan, W.J. (1971). Convection plumes in the lower mantle. Nature 230, 42-43.

Moritz, R., Rezeau, H., Ovtcharova, M., Tayan, R., Melkonyan, R., Hovakimyan, S. \& Putlitz, B. (2016). Long-lived, stationary magmatism and pulsed porphyry systems during Tethyan subduction to post-collision evolution in the southernmost Lesser Caucasus, Armenia and Nakhitchevan. Gondwana Research 37, 465-503. 
Morra, G., Yuen, D. A., King, S. D., Lee, S. M. \& Stein, S. (Eds.). (2015). Subduction Dynamics: From Mantle Flow to Mega Disasters, John Wiley \& Sons, 211.

Motaghi, K., Tatar,M., Priestley, K., Romanelli, F., Doglioni, C. \& Panza, G.F. (2015). The deep structure of the Iranian Plateau. Gondwana Research 28, 407-418.

Motavalli-Anbaran, S. H., Zeyen, H., Brunet, M. F., \& Ardestani, V. E. (2011). Crustal and lithospheric structure of the Alborz Mountains, Iran, and surrounding areas from integrated geophysical modeling. Tectonics 30, 1-16.

Motoki, M. H. \& Ballmer, M. D. (2015). Intraplate volcanism due to convective instability of stagnant slabs in the Mantle Transition Zone. Geochemistry, Geophysics, Geosystems, 16, 538-551.

Murphy, D. T., Collerson, K. D. \& Kamber, B. S. (2002). Lamproites from Gaussberg, Antarctica: possible transition zone melts of Archaean subducted sediments. Journal of Petrology 43, 981-1001.

Nabatian, G., Ghaderi, M., Neubauer, F., Honarmand, M., Liu, X., Dong, Y. \& Bernroider, M. (2014). Petrogenesis of Tarom high-potassic granitoids in the Alborz-Azarbaijan belt, Iran: Geochemical, $\mathrm{U}-\mathrm{Pb}$ zircon and $\mathrm{Sr}-\mathrm{Nd}-\mathrm{Pb}$ isotopic constraints. Lithos 184, 324-345.

Nafi Toksöz, M., Van der Hilst, R. D., Sun, Y. \& Zhang, H. (2010). Seismic tomography of the Arabian-Eurasian collision zone and surrounding areas. Monitoring Research Review no number, 504-513

Neill, I., Meliksetian, K., Allen, M. B., Navasardyan, G. \& Kuiper, K. (2015). Petrogenesis of ma fi c collision zone magmatism: The Armenian sector of the Turkish - Iranian Plateau. Chemical Geology 403, 24-41.

Nicolas, A., \& Jackson, M. (1982). High temperature dikes in peridotites: origin by hydraulic fracturing. Journal of Petrology 23, 568-582.

Niu, Y. \& Hekinian, R. (1997). Spreading-rate dependence of the extent of mantle melting beneath ocean ridges. Nature 385, 326.

Novella, D. \& Frost, D. J. (2014). The Composition of Hydrous Partial Melts of Garnet Peridotite at 6 GPa: Implications for the Origin of Group II Kimberlites. Journal of Petrology 55, 2097-2124.

O'Brien, H. E., Irving, A. J., McCallum, I. S. \& Thirlwall, M. F. (1995). Strontium, neodymium, and lead isotopic evidence for the interaction of post-suhduction asthenospheric potassic mafic magmas of the Highwood Mountains, Montana, USA, with ancient Wyoming craton lithospheric mantle. Geochimica et Cosmochimica Acta 59, 4539-4556. 
Ohtani, E. \& Zhao, D. (2009). The role of water in the deep upper mantle and transition zone: dehydration of stagnant slabs and its effects on the big mantle wedge. Russian Geology and Geophysics 50, 1073-1078.

Ohtani, E., Litasov, K., Hosoya, T., Kubo, T. \& Kondo, T. (2004). Water transport into the deep mantle and formation of a hydrous transition zone. Physics of the Earth and Planetary Interiors 143, 255-269.

Omrani, J., Agard, P., Whitechurch, H., Benoit, M., Prouteau, G. \& Jolivet, L. (2008). Arcmagmatism and subduction history beneath the Zagros Mountains, Iran: a new report of adakites and geodynamic consequences. Lithos 106, 380-398.

Özacar, A. A., Gilbert, H. \& Zandt, G. (2008). Upper mantle discontinuity structure beneath East Anatolian Plateau (Turkey) from receiver functions. Earth and Planetary Science Letters 269, 427-435.

Özacar, A. A., Zandt, G., Gilbert, H. \& Beck, S. L. (2010). Seismic images of crustal variations beneath the East Anatolian Plateau (Turkey) from teleseismic receiver functions. Geological Society, London, Special Publications 340, 485-496.

Özdemir, Y. \& Güleç, N. (2014). Geological and geochemical evolution of the Quaternary Süphan stratovolcano, eastern Anatolia, Turkey: evidence for the LithosphereAsthenosphere interaction in post-collisional volcanism. Journal of Petrology 55, 37-62.

Özdemir, Y. (2016). Geochemistry of tholeiitic to alkaline lavas from the east of Lake Van (Turkey): Implications for a late Cretaceous mature supra-subduction zone environment. Journal of African Earth Sciences 120, 77-88.

Özdemir, Y., Karaoğlu, Ö., Tolluoğlu, A. Ü. \& Güleç, N. (2006). Volcanostratigraphy and petrogenesis of the Nemrut stratovolcano (East Anatolian High Plateau): the most recent post-collisional volcanism in Turkey. Chemical Geology 226, 189-211.

Palot, M., Pearson, D. G., Stachel, T., Stern, R. A., Le Pioufle, A., Gurney, J. J. \& Harris, J. W. (2017). The transition zone as a host for recycled volatiles: Evidence from nitrogen and carbon isotopes in ultra-deep diamonds from Monastery and Jagersfontein (South Africa). Chemical Geology 466, 733-749.

Pang, K., Chung, S., Hossein, M. \& Mahdi, M. (2013a). Lithos Eocene - Oligocene postcollisional magmatism in the Lut - Sistan region, eastern Iran : Magma genesis and tectonic implications. Lithos 180-181, 234-251.

Pang, K., Chung, S., Hossein, M., Li, X., Lee, H., Lin, T. \& Chiu, H. (2016). Lithos New age and geochemical constraints on the origin of Quaternary adakite-like lavas in the Arabia Eurasia collision zone. Lithos 264, 348-359. 
Pang, K.-N.,Chung,S.-L.,Zarrinkoub, M.H.,Lin,Y.-C., Lee,H.-Y., Lo, C.-H. \& Khatib, M.M. (2013b). Iranian ultrapotassic volcanism at $\sim 11$ Ma signifies the initiation of post-collision magmatism in the Arabia-Eurasiacollision zone. TerraNova 25, 405-413.

Pearce, J.A., Bender, J.F., De Long, S.E., Kidd, W.S.F., Low, P.J., Gner, Y., Saroglu, F., Yilmaz, Y., Moorbath, S. \& Mitchell, J.G. (1990).Genesis of collision volcanismin EasternAnatolia, Turkey. Journal of Volcanology and Geothermal Research 44, 189-229.

Pearson, D. G., Brenker, F. E., Nestola, F., McNeill, J., Nasdala, L., Hutchison, M. T. \& Vekemans, B. (2014). Hydrous mantle transition zone indicated by ringwoodite included within diamond. Nature 507, 221-224.

Persikov, E. S., Bukhtiyarov, P. G. \& Sokol, A. G. (2017). Viscosity of hydrous kimberlite and basaltic melts at high pressures. Russian Geology and Geophysics 58, 1093-1100.

Pfänder, J. A., Münker, C., Stracke, A. \& Mezger, K. (2007). Nb/Ta and Zr/Hf in ocean island basalts - implications for crust-mantle differentiation and the fate of Niobium. Earth and Planetary Science Letters 254, 158-172.

Pilet, S. (2015). Generation of low-silica alkaline lavas: Petrological constraints, models, and thermal implications. The interdisciplinary Earth: A volume in Honor of Don L. Anderson: Geological Society of America Special Paper 514, 281-304.

Pilet, S., Baker, M. B. \& Stolper, E. M. (2008). Metasomatized lithosphere and the origin of alkaline lavas. Science 320, 916-919.

Piromallo, C. \& Morelli, A. (2003). P wave tomography of the mantle under the Alpine-Mediterranean area. Journal of Geophysical Research: 108 . doi:10.1029/2002JB001757.

Plank, T. \& Langmuir, C.H. (1998) The chemical composition of subducting sediment and its consequences for the crust and mantle. Chemical geology 145, 325-394.

Platevoet, B., Elitok, Ö., Guillou, H., Bardintzeff, J. M., Yagmurlu, F., Nomade, S. \& Özgür, N. (2014). Petrology of Quaternary volcanic rocks and related plutonic xenoliths from Gölcük volcano, Isparta Angle, Turkey: Origin and evolution of the high-K alkaline series. Journal of Asian Earth Sciences 92, 53-76.

Prelević, D., Foley, S. F., Romer, R. \& Conticelli S. (2008). Mediterranean Tertiary lamproites derived from multiple source components in postcollisional geodynamics. Geochimica et Cosmochimica Acta 72, 2125-2156.

Prelević, D., Akal, C., Foley, S. F., Romer, R. L., Stracke, A. \& Van Den Bogaard, P. (2012). Ultrapotassic mafic rocks as geochemical proxies for post-collisional dynamics of orogenic lithospheric mantle: the case of southwestern Anatolia, Turkey. Journal of Petrology 53, 1019-1055. 
Prelević, D., Akal, C., Romer, R. L., Mertz-Kraus, R. \& Helvaci, C. (2014). Magmatic response to slab tearing: Constraints from the afyon alkaline volcanic complex, Western Turkey. Journal of Petrology 56, 527-562.

Prelević, D., Stracke, A., Foley, S. F., Romer, R. L. \& Conticelli, S. (2010). Hf isotope compositions of Mediterranean lamproites : Mixing of melts from asthenosphere and crustally contaminated mantle lithosphere, Lithos 119, 297-312.

Rabinowicz, M. \& Ceuleneer, G. (2005). The effect of sloped isotherms on melt migration in the shallow mantle: a physical and numerical model based on observations in the Oman ophiolite. Earth and Planetary Science Letters 229, 231-246.

Rabinowicz, M. \& Toplis, M. J. (2009). Melt segregation in the lower part of the partially molten mantle zone beneath an oceanic spreading centre: Numerical modelling of the combined effects of shear segregation and compaction. Journal of Petrology 50, 1071-1106.

Rabinowicz, M., Genthon, P., Ceuleneer, G. \& Hillairet, M. (2001). Compaction in a mantle mush with high melt concentrations and the generation of magma chambers. Earth and Planetary Science Letters 188, 313-328.

Rabinowicz, M., Lago, B. \& Froidevaux, C. (1980). Thermal transfer between the continental asthenosphere and the oceanic subducting lithosphere: its effect on subcontinental convection. Journal of Geophysical Research: Solid Earth 85, 1839-1853.

Rajabi, S. A. R., Orabi, G. H. T. \& Rai, S. H. A. (2014). Oligocene crustal xenolith-bearing alkaline basalt from Jandaq area ( Central Iran ): implications for magma genesis and crustal nature, Island Arc 23, 125-141.

Rapp, R. P., Irifune, T., Shimizu, N., Nishiyama, N., Norman, M. D. \& Inoue, T. (2008). Subduction recycling of continental sediments and the origin of geochemically enriched reservoirs in the deep mantle. Earth and Planetary Science Letters 271, 14-23.

Rigo, A., Adam, C., Grégoire, M., Gerbault, M., Meyer, R., Rabinowicz, M. \& Bonvalot, S. (2015). Insights for the melt migration, the volcanic activity and the ultrafast lithosphere delamination related to the Yellowstone plume (Western USA). Geophysical Journal International 203, 1274-1301.

Roberts, M. P. \& Clemens, J. D. (1993). Origin of high-potassium, calc-alkaline, I-type granitoids. Geology 21, 825-828.

Rock, N.M.S. (1991). Lamprophyres. Blackie and Son, Glasgow, 285.

Rohrbach, A. \& Schmidt, M. W. (2011). Redox freezing and melting in the Earth/'s deep mantle resulting from carbon-iron redox coupling. Nature 472, 209-212. 
Rubin, A. M. (1993). Tensile fracture of rocks at high confining pressure: implications for dike propagation. Journal of Geophysical Research 98, 15919-15935.

Rüpke, L. H., Morgan, J. P., Hort, M. \& Connolly, J. A. (2004). Serpentine and the subduction zone water cycle. Earth and Planetary Science Letters 223, 17-34.

Saadat, S. \& Stern, C. R. (2012). Petrochemistry of a xenolith-bearing Neogene alkali olivine basalt from northeastern Iran. Journal of Volcanology and Geothermal Research 225-226, 13-29.

Saadat, S., Karimpour, M. H. \& Stern, C. (2010). Petrochemical Characteristics of Neogene and Quaternary Alkali Olivine Basalts from the Western Margin of the Lut Block, Eastern Iran 2, 87-106.

Saadat, S., Stern, C. R. \& Moradian, A. (2014). Petrochemistry of ultrapotassic tephrites and associated cognate plutonic xenoliths with carbonatite affinities from the late Quaternary Qa'le Hasan Ali maars, central Iran. Journal of Asian Earth Sciences 89, 108-122.

Saunders, A. D., Norry, M. J. \& Tarney, J. (1988). Origin of MORB and chemically-depleted mantle reservoirs: trace element constraints. Journal of Petrology 1, 415-445.

Scott, D. R. \& Stevenson, D. J. (1984). Magma solitons. Geophysical Research Letters 11, 11611164.

Semiz, B., Çoban, H., Roden, M. F., Özpınar, Y., Flower, M. F. \& McGregor, H. (2012). Mineral composition in cognate inclusions in Late Miocene-Early Pliocene potassic lamprophyres with affinities to lamproites from the Denizli region, Western Anatolia, Turkey: implications for uppermost mantle processes in a back-arc setting. Lithos 134, 253-272.

Şengör A.M.C , Ozeren S., Genc, T. \& Zor E (2003). East Anatolian high plateau as a mantlesupported, north-south shortened domal structure, Geophysical research letters 30, 2-5.

Şengör, A.M.C. \& Yilmaz, Y. ( 1981). Tethyan evolution of Turkey: a plate tectonic approach. Tectonophysics 75, 181-24.

Shabanian, E., Acocella, V., Gioncada, A., Ghasemi, H., \& Bellier, O. (2012). Structural control on volcanism in intraplate post collisional settings: Late Cenozoic to Quaternary examples of Iran and Eastern Turkey. Tectonics 31, 1-25.

Shafaii Moghadam, H., Ghorbani, G., Khedr, M. Z., Fazlnia, N., Chiaradia, M., Eyuboglu, Y. \& Arai, S. (2014). Late Miocene K-rich volcanism in the Eslamieh Peninsula (Saray), NW Iran: implications for geodynamic evolution of the Turkish-Iranian High Plateau. Gondwana Research 26, 1028-1050. 
Shahzeidi, M., Moayyed, M., Murata, M., Yui, T. F., Arai, S., Chen, F. \& Ahmadian, J. (2017). Late Ediacaran crustal thickening in Iran: Geochemical and isotopic constraints from the 550 Ma Mishu granitoids (northwest Iran). International Geology Review 59, 793-811.

Shaw, C. S., Heidelbach, F. \& Dingwell, D. B. (2006). The origin of reaction textures in mantle peridotite xenoliths from Sal Island, Cape Verde: the case for "metasomatism" by the host lava. Contributions to Mineralogy and Petrology 151, 681.

Shorttle, O., Maclennan, J. \& Lambart, S. (2014). Quantifying lithological variability in the mantle. Earth and Planetary Science Letters 395, 24-40.

Skobeltsyn, G., Mellors, R., Gök, R., Türkelli, N., Yetirmishli, G. \& Sandvol, E. (2014). Upper mantle $\mathrm{S}$ wave velocity structure of the East Anatolian-Caucasus region. Tectonics 33, 207221.

Sleep, N. H. (1988). Tapping of melt by veins and dikes. Journal of Geophysical Research: Solid Earth 93(B9), 10255-10272.

Sokol, A. G. \& Kruk, A. N. (2015). Conditions of kimberlite magma generation: experimental constraints. Russian Geology and Geophysics 56, 245-259.

Sparks, R. S. J., Brooker, R. A., Field, M., Kavanagh, J., Schumacher, J. C., Walter, M. J., \& White, J. (2009). The nature of erupting kimberlite melts. Lithos, 112, 429-438.

Spera, F. J. (1984). Carbon dioxide in petrogenesis III: role of volatiles in the ascent of alkaline magma with special reference to xenolithbearing mafic lavas. Contributions to Mineralogy and Petrology 88, 217-232.

Spera, F. J. (1987). Dynamics of translithospheric migration of metasomatic fluid and alkaline magma. In: Menzies, M. \& Hawkesworth, C. J. (eds) Mantle Metasomatism. London: Academic Press, 1-19.

Stampfli, G.M. (2000). Tethyan oceans. In: Bozkurt, E., Winchester, J.A., Piper, J.D.A. (Eds.), Tectonics and Magmatism in Turkey and Surrounding Area. Geological Society of London, Special Publication 173, 163-185.

Stöcklin, J. (1968). Structural history and tectonics of Iran, a review: American Association of Petroleum Geologists Bulletin 52, 1229-1258.

Streckeisen, A. (1979). Classification and Nomenclature of Volcanic Rocks, Lamprophyres, Carbonatites, and Melilitic Rocks: Recommendation and Suggestion of the IUGS, Subcommission on the Systematic of Igneous Rock. Geology 4, 331-335.

Su, B. X., Chung, S. L., Zarrinkoub, M. H., Pang, K. N., Chen, L., Ji, W. Q. \& Khatib, M. M. (2014). Composition and structure of the lithospheric mantle beneath NE Iran: constraints from mantle xenoliths. Lithos 202, 267-282. 
Sun, S. S. \& McDonough, W. S. (1989). Chemical and isotopic systematics of oceanic basalts: implications for mantle composition and processes. Geological Society, London, Special Publications 42, 313-345.

Temel, A., Gündoğdu, M.N., Gourgaud, A. \& Le Pennec, J.L. (1998) Ignim- brites of Cappadocia (Central Anatolia, Turkey): petrology and geochemistry. Journal of Volcanology and Geothermal Research 85, 447-471.

Thomson, A. R., Walter, M. J., Kohn, S. C., \& Brooker, R. A. (2016). Slab melting as a barrier to deep carbon subduction. Nature 529, 76.

Tiepolo, M., Bottazzi, P., Foley, S. F., Oberti, R., Vannucci, R. \& Zanetti, A. (2001).

Fractionation of $\mathrm{Nb}$ and $\mathrm{Ta}$ from $\mathrm{Zr}$ and $\mathrm{Hf}$ at mantle depths: the role of titanian pargasite and kaersutite. Journal of Petrology 42, 221-232.

Torabi, G., Arai, S. \& Abbasi, H. (2014). Eocene continental dyke swarm from Central Iran (Khur area). Petrology (in farsi) 2, 617-632.

Torabi, G., Bölgesi, Ş. Q., \& Eyaleti, B. Y. (2009). Subduction-related Eocene Shoshonites from the Cenozoic Urumieh-Dokhtar Magmatic Arc ( Qaleh-Khargooshi Area, Western Yazd Province, Iran ), Turkish Journal of Earth Sciences 18, 583-613.

Trønnes, R. G. (2002). Stability range and decomposition of potassic richterite and phlogopite end members at 5-15 GPa. Mineralogy and Petrology 74, 129-148.

Tumiati, S., Fumagalli, P., Tiraboschi, C. \& Poli, S. (2013). An Experimental Study on COHbearing Peridotite up to $3.2 \mathrm{GPa}$ and Implications for Crust- Mantle Recycling, Journal of Petrology 54, 453-479.

Ulmer, P. \& Sweeney, R.J. (2002). Generation and differentiation of group II kimberlites: constraints from a high-pressure experimental study to $10 \mathrm{GPa}$. Geochimica et Cosmochimica Acta 66, 2139-2153.

Ulmer, P. (2001). Partial melting in the mantle wedge-the role of $\mathrm{H} 2 \mathrm{O}$ in the genesis of mantlederived 'arc-related'magmas. Physics of the Earth and Planetary Interiors 127, 215-232.

van der Meijde, M., Marone, F., Giardini, D. \& van der Lee, S. (2003). Seismic evidence for water deep in Earth's upper mantle. Science 300, 1556-1558.

van Westrenen, W., Blundy, J. D. \& Wood, B. J. (2001). High field strength element/rare earth element fractionation during partial melting in the presence of garnet: implications for identification of mantle heterogeneities. Geochemistry, Geophysics, Geosystems 2(7), 1554-1579.

Verdel, C., Wernicke, B. P., Hassanzadeh, J. \& Guest, B. (2011). A Paleogene extensional arc flare-up in Iran. Tectonics 30, 1-20. 
Verdel, C., Wernicke, B. P., Ramezani, J., Hassanzadeh, J., Renne, P. R. \& Spell, T. L. (2007). Geology and thermochronology of Tertiary Cordilleran-style metamorphic core complexes in the Saghand region of central Iran, Geological Society of America Bulletin 119, 961-977.

Vincent, S. J., Allen, M. B., Ismail-zadeh, A. D., Foland, K. A. \& Simmons, M. D. (2005). Insights from the Talysh of Azerbaijan into the Paleogene evolution of the South Caspian region, Geological Society of America Bulletin 11/12, 1513-1533.

Wagner, C. \& Velde, D. (1986). The mineralogy of K-richterite-bearing lamproites. American Mineralogist 71, 17-37.

Walker, R. T., Gans, P., Allen, M. B., Jackson, J., Khatib, M., Marsh, N. \& Zarrinkoub, M. (2009). Late Cenozoic volcanism and rates of active faulting in eastern Iran, Geophysical Journal International 177, 783-805.

Wang, X. C., Wilde, S. A., Xu, B. \& Pang, C. J. (2016). Origin of arc-like continental basalts: Implications for deep-Earth fluid cycling and tectonic discrimination. Lithos 261, 5-45.

Wang, Y., Foley, S. F. \& Prelević, D. (2017). Potassium-rich magmatism from a phlogopite-free source. Geology 45, 467-470.

Wark, D. A. \& Watson, E. B. (1998). Grain-scale permeabilities of texturally equilibrated, monomineralic rocks. Earth and Planetary Science Letters 164, 591-605.

Waters, F. G. (1987). A suggested origin of MARID xenoliths in kimberlites by high pressure crystallization of an ultrapotassic rock such as lamproite. Contributions to Mineralogy and Petrology 95, 523-533.

Watkinson D.H. \& Wyllie P.J. (1971). Experimental study of composition join NaAlSiO4$\mathrm{CaCO} 3-\mathrm{H} 2 \mathrm{O}$ and genesis of alkalic rock - carbonatite complexes. Journal of petrology 12, 357-378.

Wiggins, C. \& Spiegelman, M. (1995). Magma migration and magmatic solitary waves in 3-D. Geophysical Research Letters 22, 1289-1292.

Willbold, M. \& Stracke, A. (2006). Trace element composition of mantle end-members: Implications for recycling of oceanic and upper and lower continental crust, Geochemistry, Geophysics, Geosystems7, 1-30.

Wilson, M. \& Bianchini, G. (1999). Tertiary-Quaternary magmatism within the Mediterranean and surrounding regions. in "The Mediterranean Basins: Tertiary Extension Within the Alpine Orogen', B. Durand, L. Jolivet, F. Horvath, M. Seranne, eds. Geolgical Society Special Publication 156, 141-168.

Wilson, M. (1989). Igneous Petrogenesis: a Global Tectonic Approach. Chapman \& Hall, London, 466. 
Wilson, M., Tankut, A. \& Guleg, N. (1997). Tertiary volcanism of the Galatia province, northwest Central, Lithos 42, 105-121.

Woolley, A. R., Bergman, S. C., Edgar, A. D., Le Bas, M. J., Mitchell, R. H., Rock, N. M. \& Scott Smith, B. H. (1996). Classification of lamprophyres, lamproites, kimberlites, and the kalsilitic, melilitic, and leucitic rocks. Canadian Mineralogist 34, 175-186.

Yamato, P., Kaus, B. J., Mouthereau, F. \& Castelltort, S. (2011). Dynamic constraints on the crustal-scale rheology of the Zagros fold belt, Iran. Geology 39, 815-818.

Yeganehfar, H., Ghorbani, M. R., Shinjo, R. \& Ghaderi, M. (2013). Magmatic and geodynamic evolution of Urumieh-Dokhtar basic volcanism, Central Iran: major, trace element, isotopic, and geochronologic implications. International Geology Review 55, 767-786.

Yılmaz, A., Adamia, S., Chabukiani, A., Chkhotua, T., Erdogan, K., Tuzcu, S. \& erKarabiyıkoglu, M. (2000). Structural Correlation of the Southern Transcaucasus (Georgia)-Eastern Pontides (Turkey). In: Geological Society, London, Special Publications 173, 171-182.

Yoder H.S. \& Tilley C.E. (1962). Origin of basalt magmas: an experimental study of natural and synthetic rock systems. Journal of petrology 3, 342-532.

Zabelina, I., Koulakov, I., Amanatashvili, I., El Khrepy, S. \& Al-Arifi, N. (2016). Seismic structure of the crust and uppermost mantle beneath Caucasus based on regional earthquake tomography. Journal of Asian Earth Sciences 119, 87-99.

Zindler, A. \& Hart, S. (1986). Chemical geodynamics. Annual Review of Earth and Planetary Science Letters 14, 493-571.

\section{FIGURE CAPTIONS}

Figure 1. Regional tectonic setting of the Turkish Iranian Plateau (TIP) showing the main tectonic divisions related to the Arabian and Eurasian plates. Grey and red shaded areas illustrate the distributions of continental magmatism older than $\sim 100 \mathrm{Ma}$ and younger than $80 \mathrm{Ma}$, respectively (adapted from the Middle East geological map, Haghipour et al., 2009). Key features: EKP, Erzurum- Kars Plateau; NAF, North Anatolian Fault; IAE, Izmir-Ankara- 
Erzincan; TF, Tabriz Fault; SSZ, Sanandaj-Sirjan Zone; UDM, Urmieh-Dokhtar Magmatic Zone, GVP, Galatia Volcanic Province; CAP, Central Anatolia Province; KAI, Kırka-Afyon-Isparta.

Figure 2. Geochemical variation diagrams used to classify the investigated lavas. Samples are restricted to $\mathrm{SiO}_{2}<\sim 55 \mathrm{wt} \%$. The major element data are recalculated to a $100 \%$ anhydrous basis. (a) Total Alkalis versus Silica diagram (TAS; Le Bas et al., 1986); dotted line is the Irvine \& Baragar (1971) boundary between alkaline and sub-alkaline rocks. (b) $\mathrm{K}_{2} \mathrm{O}$ versus $\mathrm{Na}_{2} \mathrm{O}$ diagram illustrating the classification of lavas into sodic, transitional from sodic to potassic, potassic and ultrapotassic series.

Figure 3. (a,b) Primitive mantle normalized (Sun \& McDonough, 1989) multi-element distribution patterns of the lavas (shaded areas) and most primitive lavas (lines). The trace element patterns of the investigated lavas define two main types: (a) subduction influenced-and (b) OIB-like. (c) Chondrite-normalized (Sun \& McDonough, 1989) REE patterns of sodic-LK lavas are consistent with a fractional crystallization (FC) trend produced by 20 to $60 \%$ fractionation of cpx (55)-plg (10)-ol (35) from the most primitive sodic-LK lava or with the mixing of sodic-LK and UK lavas. The most primitive UK, sodic-HK and -LK lavas taken as the starting compositions are from Aghazadeh et al. (2015), Kheikhah et al. (2013) and Neill et al. (2015), respectively. Data sources: average kimberlite type I: Becker \& Le Roex, 2006, the MTZderived lamproite: Murphy et al., 2002 and OIB: Sun \& McDonough, 1989.

Figure 4. ${ }^{143} \mathrm{Nd} /{ }^{144} \mathrm{Nd}$ versus ${ }^{87} \mathrm{Sr} /{ }^{86} \mathrm{Sr}$ for each group of lavas compared with various mantle components. Data sources: DMM: Depleted MORB Mantle and Oceanic Island Basalt (OIB) after Zindler \& Hart (1986); group I, II and transitional kimberlites: Becker \& Le Roex, 2006; GLOSS: global subducting sediment, Plank \& Langmuir (1998); cumulative xenoliths from NW of Iran: Khezerlou et al. (2017). 
Figure 5. Map views through S- wave tomographic model at $60 \mathrm{~km}$ (a) and $150 \mathrm{~km}$ (b) depth, adapted from Fichtner et al. (2013). (c) Structural map showing the main tectonic units of the Iranian Plateau including major faults (black bold lines), hidden faults (black dashed lines) and recent volcanic fields (shaded red). The $150 \mathrm{~km}$ depth section through the CPs, extracted from Alinaghi et al. (2007) is shaded in pink. Black arrows represent the projections of the horizontally oriented directions of maximum stress derived from Aktug et al. (2013) (a) and Masson et al. (2014) (c) and GPS data (b). Blue lines A-B, C-D, E-F and G-H correspond to the sections along which the vertical tomography maps in Fig.6 have been extracted. Marked features: GVP: Galatia Volcanic Province; CAP: Central Anatolia Province, KAI: Kırka-Afyon-Isparta, CATB: Central Anatolian Thrust Belt, EAF: East Anatolian Fault, NAF: North Anatolia Fault, TJK: Triple Junction Karıva. Name of Quaternary volcano (triangles); Bi: Bingol, Er: Erciyes, Ha: Hasandagh, Ka: Karacadag. GC: Great Caucasus, LC: Lesser Caucasus, KB: Kura Basin, EP: East Pontides, AL: Alborz, KPt: Kopet Dagh, CATB: Central Anatolian Thrust Belt, NAF: North Anatolia fault, TF: Tabriz fault, MF: Mosha fault, GKF: Great Kavir fault, NBF: Naiband fault, NF: Nehbandan fault.

Figure 6. (a) Vertical P-wave velocity anomaly cross-section joining the Zagros to the Greater Caucasus, following the line A-B in Fig. 5c, indicating low velocity anomalies beneath the TIP (from Koulakov et al., 2012). CPs (Compaction Pockets) correspond to red/orange zones of low velocity. The solid line represents the lithosphere-asthenosphere boundary (LAB, after Zabelina et al., 2016) and dashed lines represent the overlapping shallow depth seismic structure studied by Zabelina et al. (2016). (b) S-wave velocity anomaly across the Central-East Iranian blocks joining the Zagros to Kopet Dagh (after Motaghi et al., 2015). The location of the profile is shown in Fig. 5c. The velocity range through and surrounding the main $\mathrm{CP}$ (located at $\sim 150 \mathrm{~km}$ 
depth) is 4.2 to $3.8 \mathrm{kms}^{-1}$. White squares represent the LAB. (c) Vertical sections through the Swave velocity tomographic model adapted from Fichtner et al. (2013), following the lines E-F and G-H in Fig. 5b. CPs are centred at $150 \mathrm{~km}$ depth and extend down to $300 \mathrm{~km}$ depth.

Figure 7. Middle East large-scale tomography model (P-wave anomalies) by Nafi Toksöz et al. (2010). (a) at $700 \mathrm{~km}$ and (b) at $500 \mathrm{~km}$ depth, respectively. Dashed purple lines are plate boundaries, dashed red lines indicate the borders of low velocity anomalies and brownish-orange areas are the CPs identified in this study.

Figure 8. Pressure-temperature diagram illustrating: (a) the solidus of different mantle components determined by melting experiments and the mantle adiabatic temperature (after Katsura et al., 2010); (b) and (c) phase relationships of hydrous/carbonated phases in the upper mantle. Solid and dashed lines colour code: dark blue, solidus of dry peridotite from Herzberg et al. (2000); pink, solidus of pyrolite (with $2 \mathrm{wt} \% \mathrm{H}_{2} \mathrm{O}$, after Litasov \& Ohtani, 2002) and orange, solidus of vapour-saturated peridotite (Green, 2015). Dashed red and blue lines in (c) show the Wadsleyite (Wd) and Ringwoodite (Rw)-out boundaries, respectively. Solid blue and green lines (b and c) show the K-richterite (Kr) and Ca-amphibole (amph)-out boundaries (Konzett et al. 1997 and Green, 2015). Numbers correspond to: (1) solidus of carbonated eclogite (with $4.4 \mathrm{wt}$ \% $\mathrm{CO}_{2}$ ) (Ghosh et al., 2014); (2) solidus of carbonated eclogite (Keshav \& Gudfinnson, 2010); (3) solidus of fertile peridotite (with $5 \mathrm{wt} \% \mathrm{CO}_{2}$ ) (Rohrbach \& Schmidt, 2011); (4, 5) Solidus of alkali-rich peridotite (with $5 \mathrm{wt} \% \mathrm{CO}_{2}$ ) (Ghosh et al., 2009); (6) solidus of carbonate-bearing fertile peridotite (Dasgupta \& Hirschmann, 2006); (7) solidus of phlogopite-bearing carbonated peridotite (Enggist et al., 2012); (8) solidus of kimberlite and (9) MARID xenoliths (Eggler, 1989). Phase relations in (a) of K-richterite with phlogopite from Konzett et al. (1997), phlogopite with magnesite from Enggist et al. (2012), Ca-amphibole and carbonate from Green 
(2015). Dark quadrant indicates that the corresponding phase is present. Abbreviations: Kr, Krichterite; Ph, phlogopite; Amph; Ca-amphibole; Mag; magnesite and Carb; Carbonate.

Figure 9. ( $a$ and $b$ ) Sketches proposed for the development and ascent of CPs from the low velocity layer at the top of the MTZ towards the surface. In (a) the upper mantle is motionless, whereas in (b) the low velocity layer and the overlying mantle move north with the BMW. In (a) synchronous sets of diapirs develop with a width of $\sim 100 \mathrm{~km}$, whereas in (b) the northern diapirs develop before the southern ones. At 240 depth ( $8 \mathrm{GPa}$ ), the group of diapirs form a $\mathrm{CP}$, in relation to the crystallization of interstitial volatile-rich melt of hydrated-carbonated phases (stage 1). When this $\mathrm{CP}$ rises to $195 \mathrm{~km}$ depth (6.5 GPa, stage 2), hydrated-carbonated phases destabilise. Finally at depths shallower than $150 \mathrm{~km}$ (stage 3), hydrous melting occurs. During stages 1, 2 and 3 the accumulation of melt inside the CPs leads to a marked increase of the effective pressure at their top, hydro-fracturating of the surrounding mantle and the generation of dyke swarms. It is deduced that during stage 1, the melt extracted from the CPs has a composition similar to that of the UK lavas; such melts may form cumulates at shallower depths ((c), stage 1). During the second stage, the extracted melt is similar to OIB-like melts (sodic-HK lavas). Finally, during stage 3, melting of fertile peridotite leads to OIB-like melts (sodic-LK lavas).

Figure 10. (a) N-MORB normalized (Sun \& McDonough, 1989) and (b) GLOSS normalized (Plank \& Langmuir, 1998) trace element patterns of the most primitive UK lavas (from Aghazadeh et al., 2015). Comparisons are shown with average type II kimberlite (Becker \& Le Roex, 2006), MTZ-derived lamproite (Murphy et al., 2002) and the continental crust of NW Iran (Shahzeid et al., 2017). 
Figure 11. (a) $\mathrm{CaO}+\mathrm{Na}_{2} \mathrm{O}+\mathrm{K}_{2} \mathrm{O}$ (wt \%) versus $\mathrm{SiO}_{2}+\mathrm{Al}_{2} \mathrm{O}_{3}$ (wt\%) diagram illustrating the effect of variable $\mathrm{CO}_{2}$ on hybrid peridotite-derived melts at $3 \mathrm{GPa}$ and on the alkalis and silica contents of primary melts. When the $\mathrm{CO}_{2}$ content of the melt reacting with the mantle increases, the silica under-saturation and, or, the alkalinity of the resulting melts after reaction also increase. The OIB field, trajectory of arrows and numbers next to them are from Mallik \& Dasgupta, 2014. (b) $\mathrm{SiO}_{2}$ vs $\mathrm{K}_{2} \mathrm{O}$ diagram showing the composition of older potassic plutonic rocks (blue squares) and TK lavas (yellow circles). This diagram illustrates that melt resulting from melting of phlogopitebearing mantle at 1 (Condamine \& Médard, 2014) and 3 GPa (Condamine et al., 2016) cannot explain the high $\mathrm{K}_{2} \mathrm{O}$ contents of the UK lavas ( $\left.12 \mathrm{wt} \%\right)$, but may explain the $\mathrm{K}_{2} \mathrm{O}$ content of plutonic rocks at $1 \mathrm{GPa}$.

Figure 12. Sr-Nd isotope compositions vs major elements $\left(\mathrm{K}_{2} \mathrm{O}\right.$ wt $\%, \mathrm{Na}_{2} \mathrm{O}$ wt $\%, \mathrm{MgO}$ wt $\%$ and $\mathrm{SiO}_{2}$ wt \%) illustrating the effects of mixing (a-c), fractional crystallization (FC) and crustal contamination (CC) (d-f) for alkaline magmatism in the TIP. In (a-c) the black and orange dashed lines are mixing lines between the most primitive sodic-LK lavas and UK lavas (1) and cumulate xenoliths (2), respectively. The numbers on the lines specify the mixing proportions between the two compositions. (e-f) illustrate that the composition of A-type granitoids (black crosses) may result from FC of alkaline lavas (e.g., sodic-LK lavas) affected by CC. In addition, the isotopic heterogeneity of the UK and sodic-LK lavas indicates that FC alone cannot explain their compositional diversities. Continental crust field from the TIP based on data from Shahzeidi et al. (2017). Symbols are as in Fig. 2.

Figure 13. Schematic geological map of the TIP showing the age distribution and composition of (a) young volcanic rocks ( $<11 \mathrm{Ma}$ ) and (b) volcanic and plutonic rocks from $11 \mathrm{Ma}$ to $\sim 80 \mathrm{Ma}$ 
(age references included in Supplementary Data Appendix Table 2). Pink areas show the distribution of CPs at $150 \mathrm{~km}$ depth (adapted from Figs 5 and 6).

Figure 14. (a) Total alkali vs silica diagram (TAS; Le Bas et al., 1986) for (a) volcanic and (b) plutonic rocks from 11 to $\sim 80 \mathrm{Ma}$ in the TIP. TK, sodic HK-and- LK lava fields shown for comparison. The solid bold line highlights the transition between alkaline and subalkaline magmatic series (after Irvine \& Baragar, 1971). (c) Diagram relating volcanic and plutonic magmatic ages (Ma) and compositions throughout the TIP (references for age and composition listed in Supplementary Data Appendix Table 2). 


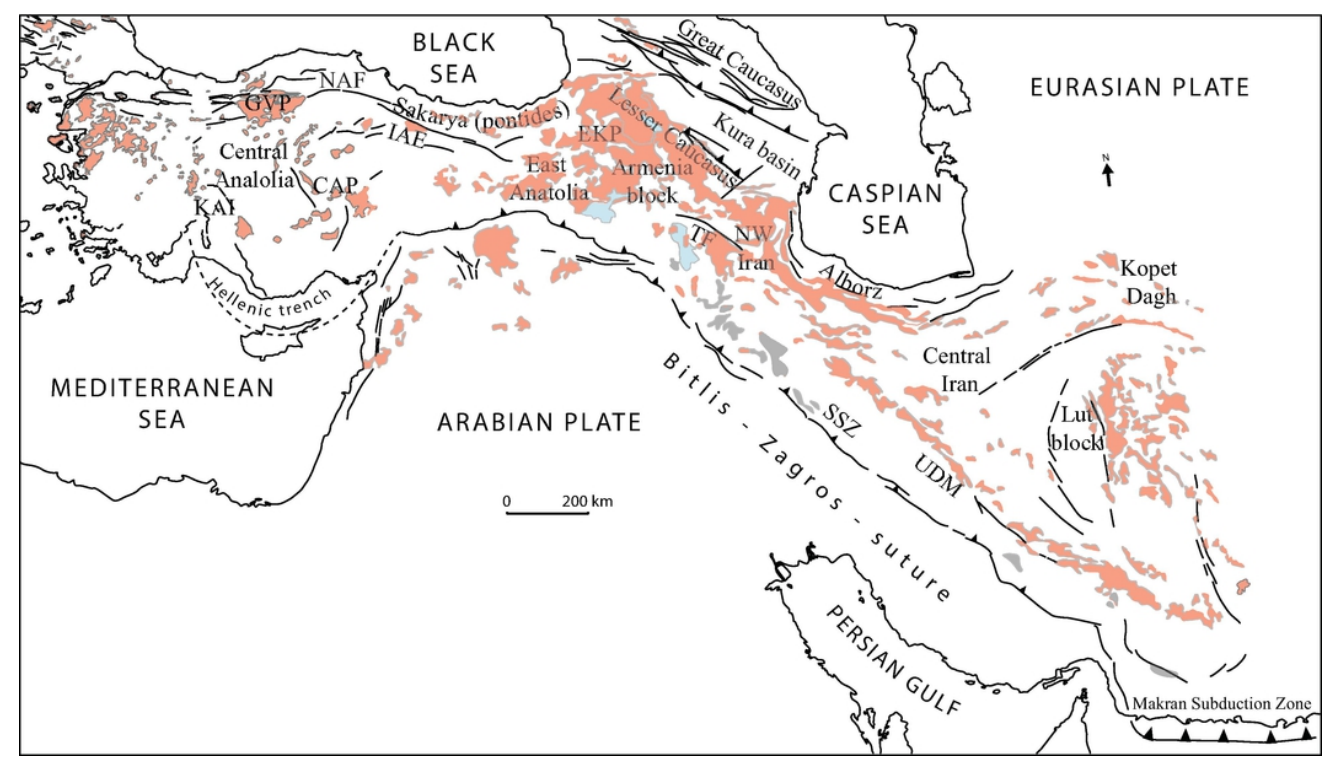

FIG. 1: Regional tectonic setting of the Turkish Iranian Plateau (TIP) with the main tectonic divisions related to the Arabian and Eurasian plates. Grey and red shaded areas illustrate the distributions of the continental magmatism older than $\sim 100 \mathrm{Ma}$ and younger than $80 \mathrm{Ma}$, respectively (adapted from the Middle East geological map, Haghipour et al., 2009). Key features: EKP, Erzurum- Kars plateau; NAF, North Anatolian fault; IAE, Izmir-Ankara-Erzincan; TF, Tabriz fault; SSZ, Sanandaj-Sirjan Zone; UDM, Urmieh-Dokhtar Magmatic Zone, GVP, Galatia Volcanic Province; CAP, Central Anatolia Province; KAI, Kırka-Afyon-Isparta.

$89 \times 51 \mathrm{~mm}(300 \times 300$ DPI $)$ 

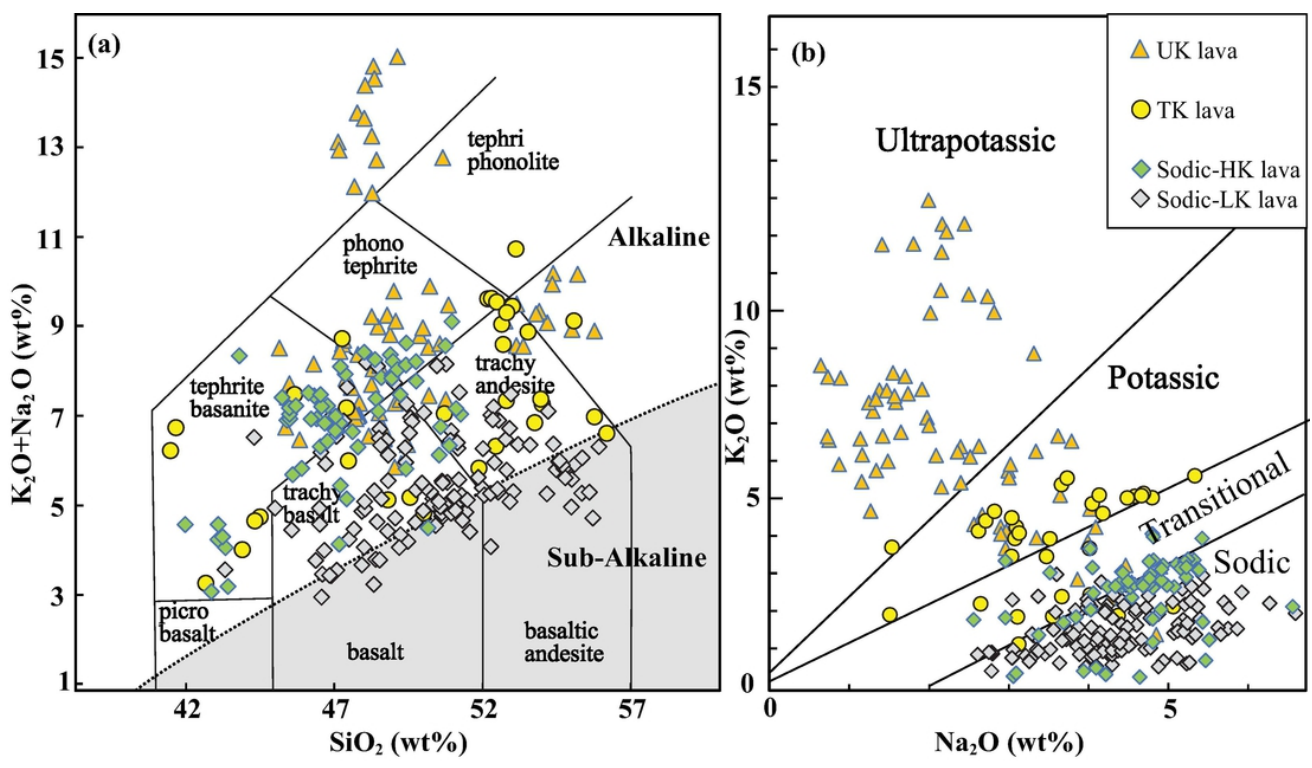

FIG. 2: Geochemical variation diagrams used to classify the investigated lavas. Samples are restricted to SiO2 < 55 wt. \%. The major elements data are recalculated to a $100 \%$ anhydrous basis. a) Total Alkali versus Silica diagram (TAS; Le Bas et al., 1986); solid line is Irvine \& Baragar (1971) 's boundary between alkaline and sub-alkaline rocks, b) $\mathrm{K} 2 \mathrm{O}$ versus $\mathrm{Na2O}$ diagram illustrating the classification of lavas into sodic, transitional from sodic to potassic, potassic and ultrapotassic series.

$93 \times 53 \mathrm{~mm}(300 \times 300 \mathrm{DPI})$ 

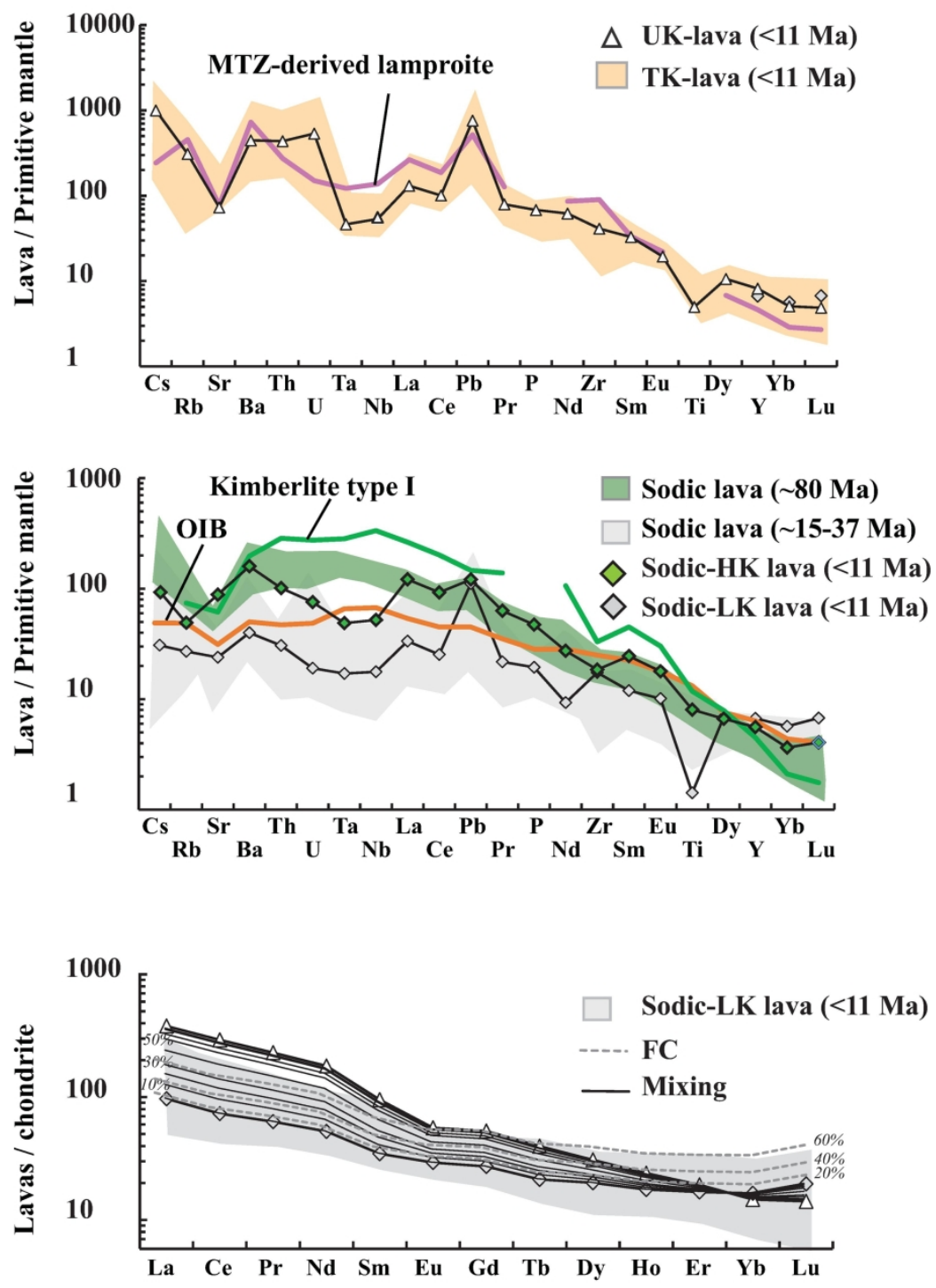

FIG. 3: Primitive mantle normalized (Sun \& McDonough, 1989) multi-element distribution patterns of the lavas (shaded area) and most primitive lavas (line). The various patterns of the investigated lavas define two main types of patterns: a) subduction influenced-and b) OIB-like. (c) Diagram illustrating that chondrite-normalized (Sun \& McDonough, 1989) REE patterns of sodic-LK lavas are in agreement with fractional crystallization (FC) trend produced by 20 to $60 \%$ fractionation of cpx (55)-plg (10)-ol (35) from the most primitive sodic- LK lava or with the mixing of sodic -LK and UK lavas. The most primitive UK, sodic-HK and -LK taken as starting composition from Aghazadeh et al. (2015), Kheikhah et al. (2013) and Neill et al. 2015, respectively. Data sources: average kimberlite type I: Becker \& Le Roex, 2006, the MTZderived lamproite: Murphy et al., 2002 and OIB: Sun \& McDonough, 1989. 


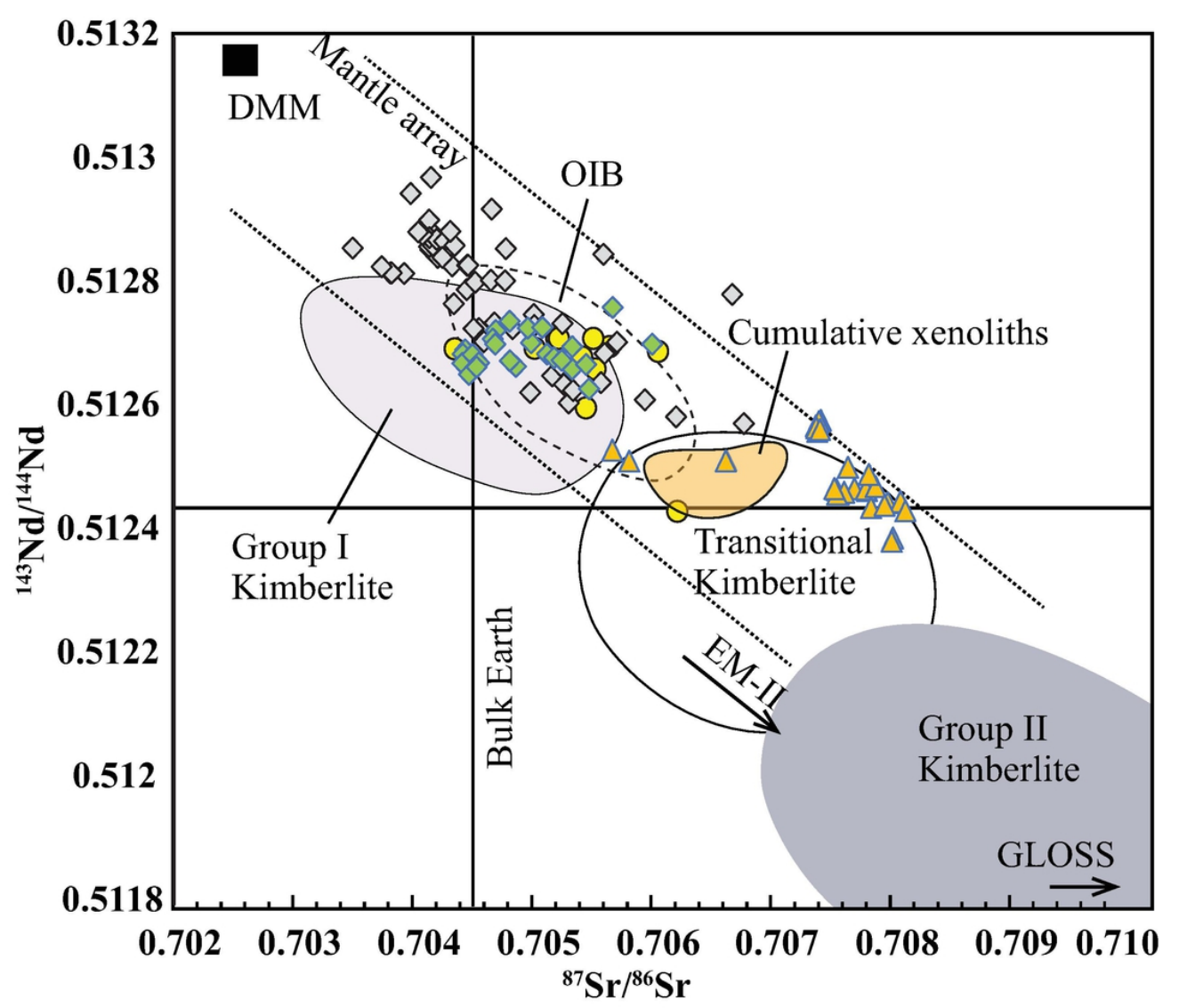

FIG. $4: 143 \mathrm{Nd} / 144 \mathrm{Nd}$ versus $87 \mathrm{Sr} / 86 \mathrm{Sr}$ diagram for each group of lavas compared with the mantle components. Data sources: DMM: Depleted MORB Mantle and Oceanic Island Basalt: OIB after Zindler \& Hart, 1986, group I, II and transitional Kimberlites: Becker \& Le Roex, 2006, GLOSS: global subducting sediment, Plank \& Langmuir, 1998, cumulative xenoliths from NW of Iran; Khezerlou et al. (2017).

$93 \times 80 \mathrm{~mm}(300 \times 300 \mathrm{DPI})$ 


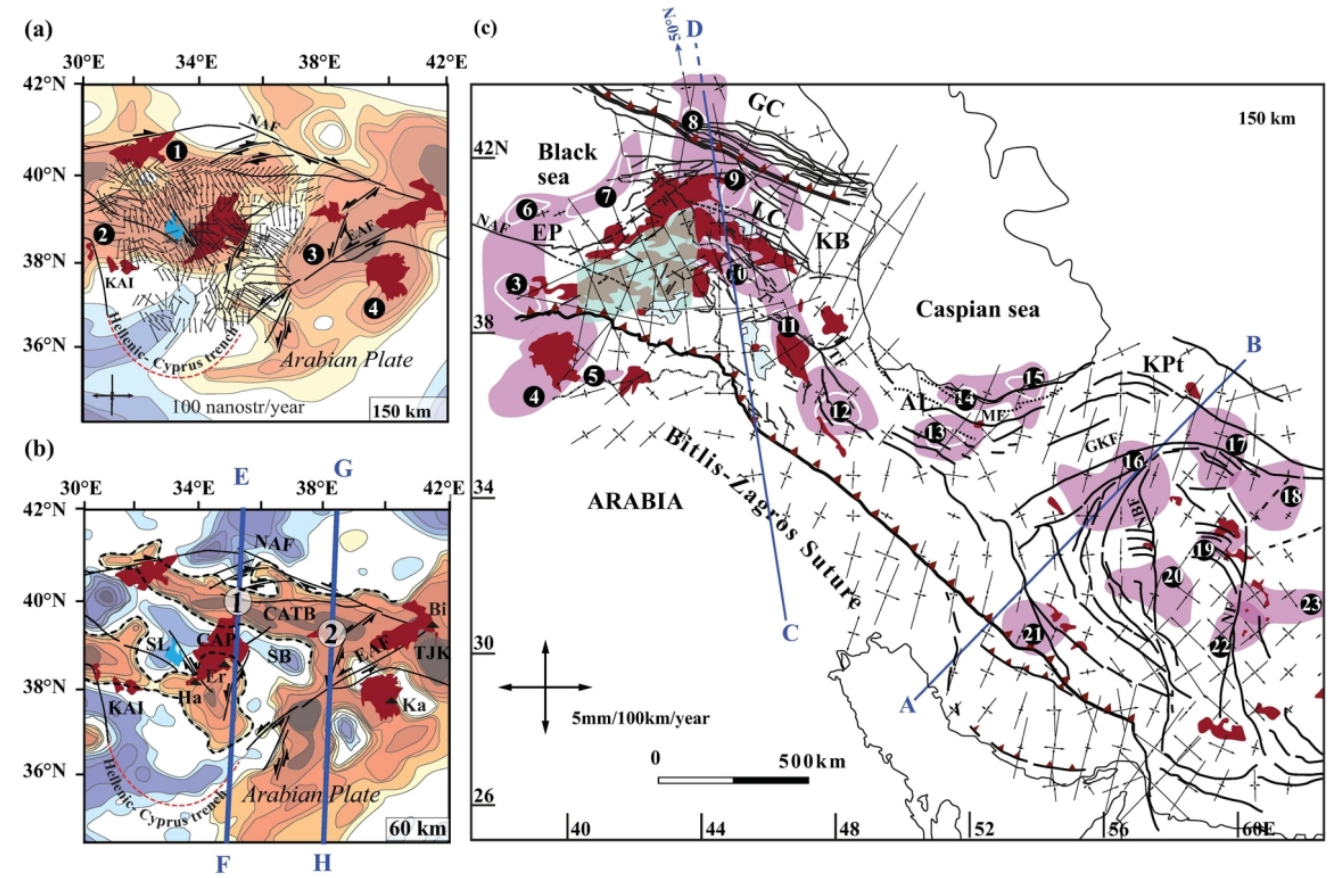

FIG. 5: Map views through S- wave tomographic model velocity at $60 \mathrm{~km}$ (a) and $150 \mathrm{~km}$ (b) depth adapted from Fichtner et al. (2013). (c) Structural map showing the main tectonic units of the Iranian plateau including major faults (black bold line), hidden fault (black dashed line) and recent volcanic fields (shaded red). The $150 \mathrm{~km}$ deep section of the CPs, extracted from Alinaghi et al. (2007) are shaded in pink. Black arrows represent the projections of the horizontally oriented directions of maximum strain derived from Aktug et al. (2013) (a) and Masson et al. (2014) (c)'s GPS data (b). Blue lines A-B, C-D, E-F and G-H correspond to the paths along which figures 6 vertical tomography maps has been extracted. Marked features: GVP: Galatia Volcanic Province; CAP: Central Anatolia Province, KAI: Kırka-Afyon-Isparta, CATB: Central Anatolian Thrust Belt, EAF: East Anatolian Fault, NAF: North Anatolia Fault, TJK: Triple Junction Karıava. Name of Quaternary volcano (triangles); Bi: Bingol, Er: Erciyes, Ha: Hasandagh, Ka: Karacadag. GC: Great Caucasus, LC: Lesser Caucasus, KB: Kura Basin, EP: East Pontides, AL: Alborz, KPt: Kopet Dagh, CATB: Central Anatolian Thrust Belt, NAF: North Anatolia fault, TF: Tabriz fault, MF: Mosha fault, GKF: Great Kavir fault, NBF: Naiband fault, NF: Nehbandan fault. 

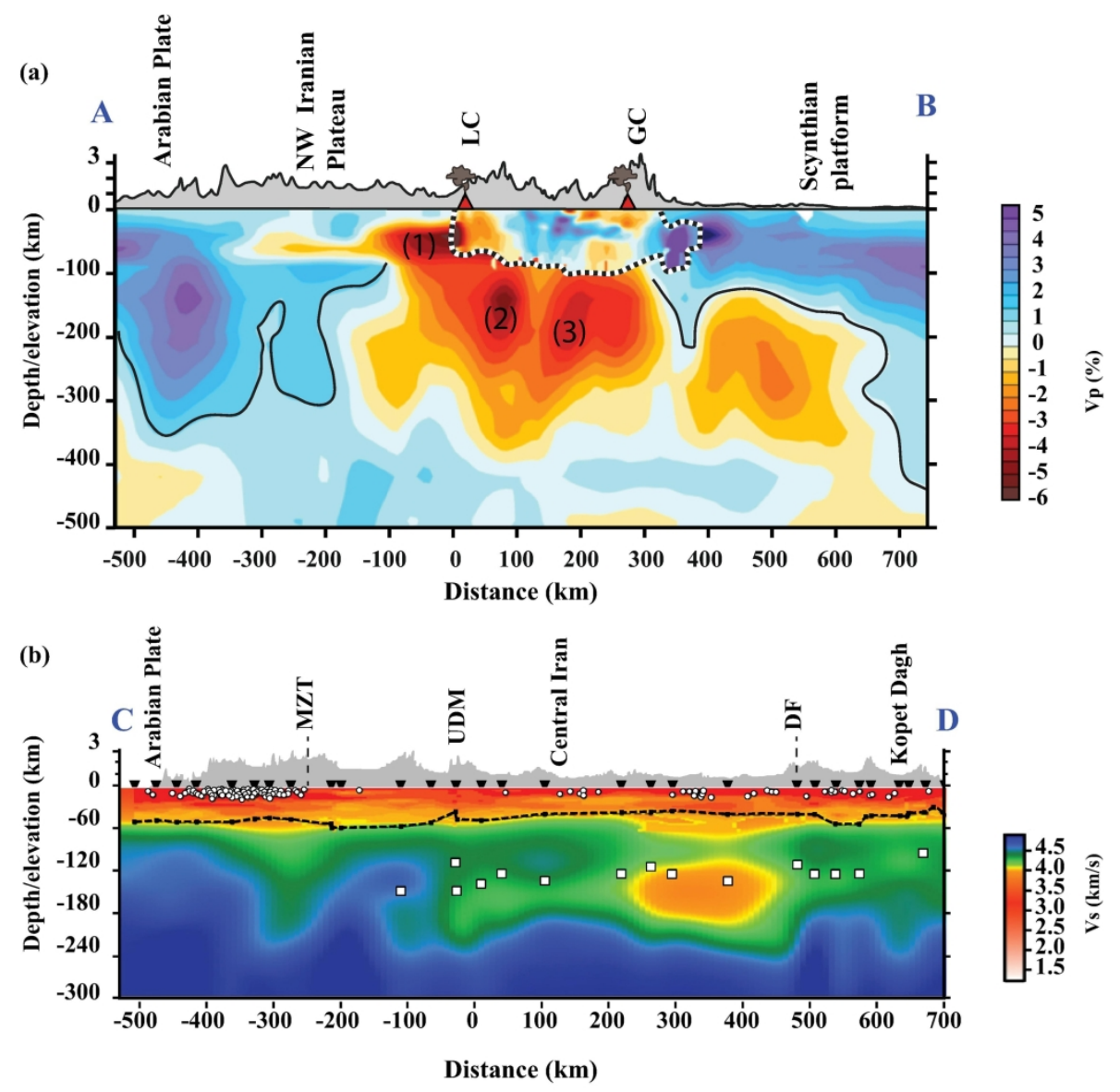

(c)

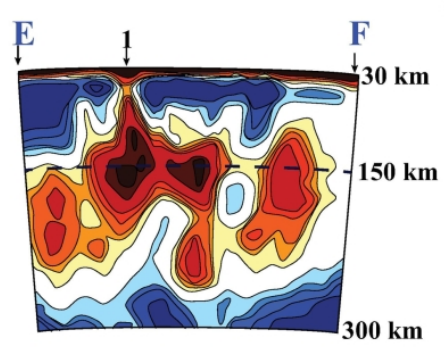

(d)

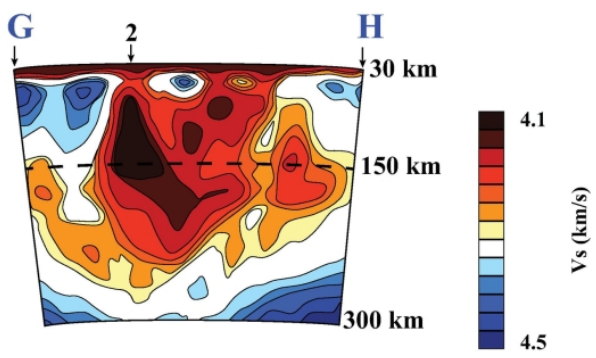

FIG. 6: (a) vertical P-waves velocity anomaly cross-sections joining the Zagros to the Great Caucasus, following the A-B line from figure $5 c$, indicates low velocity anomalies beneath the TIP (from Koulakov et al., 2012). CPs (Compaction Pockets) correspond to red zones of low velocity. The solid line represents the lithosphere-asthenosphere boundary (LAB-after Zabelina et al., 2016) and dashed lines represent the overlapping shallow depth seismic structure studied by Zabelina et al. (2016).b) S-waves velocity anomaly across Central-East Iranian blocks joining Zagros to Kopet Dagh (after Motaghi et al., 2015). The location of the profile is shown Fig. 5c. The velocity ranges through and surrounding the main CP (located at $\sim 150 \mathrm{~km}$ depth) is 4.2 to $3.8 \mathrm{kms}-1$. White squares in represent the LAB. c) Vertical sections through S- wave velocity tomographic model adapted after Fichtner et al. (2013), following the lines E-F and G-H from figure 5b. CPs are centred at $150 \mathrm{~km}$ depth and extend down to $300 \mathrm{~km}$ depth. 

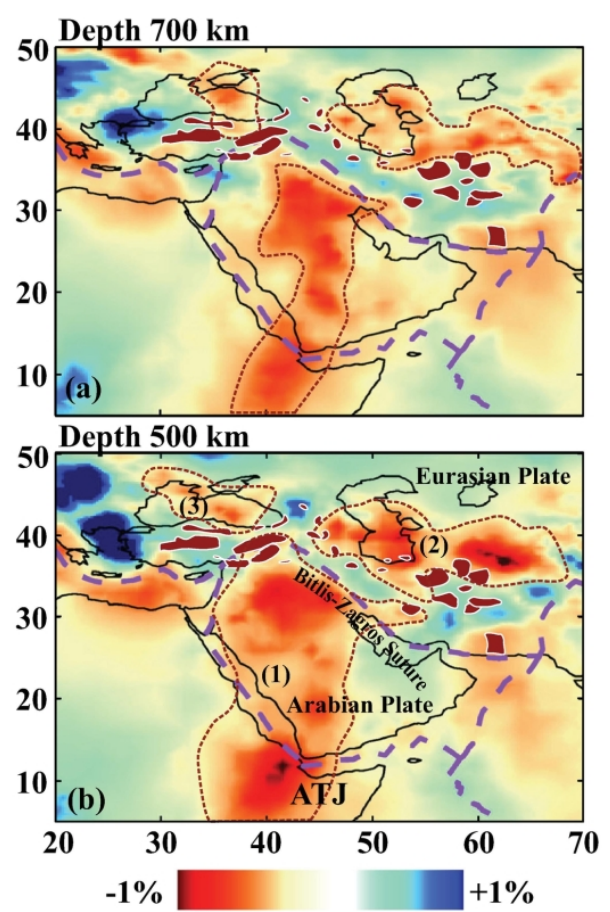

FIG. 7: Middle East large-scale tomography model (P-wave anomalies) by Nafi Toksöz et al. (2010). (a) at $700 \mathrm{~km}$ and (b) at $500 \mathrm{~km}$ depth, respectively. Dashed purple lines are plate boundaries, dashed red lines are border of low velocity anomalies and brownish-red area are the CPs identified in this study.

$199 \times 199 \mathrm{~mm}(300 \times 300 \mathrm{DPI})$ 

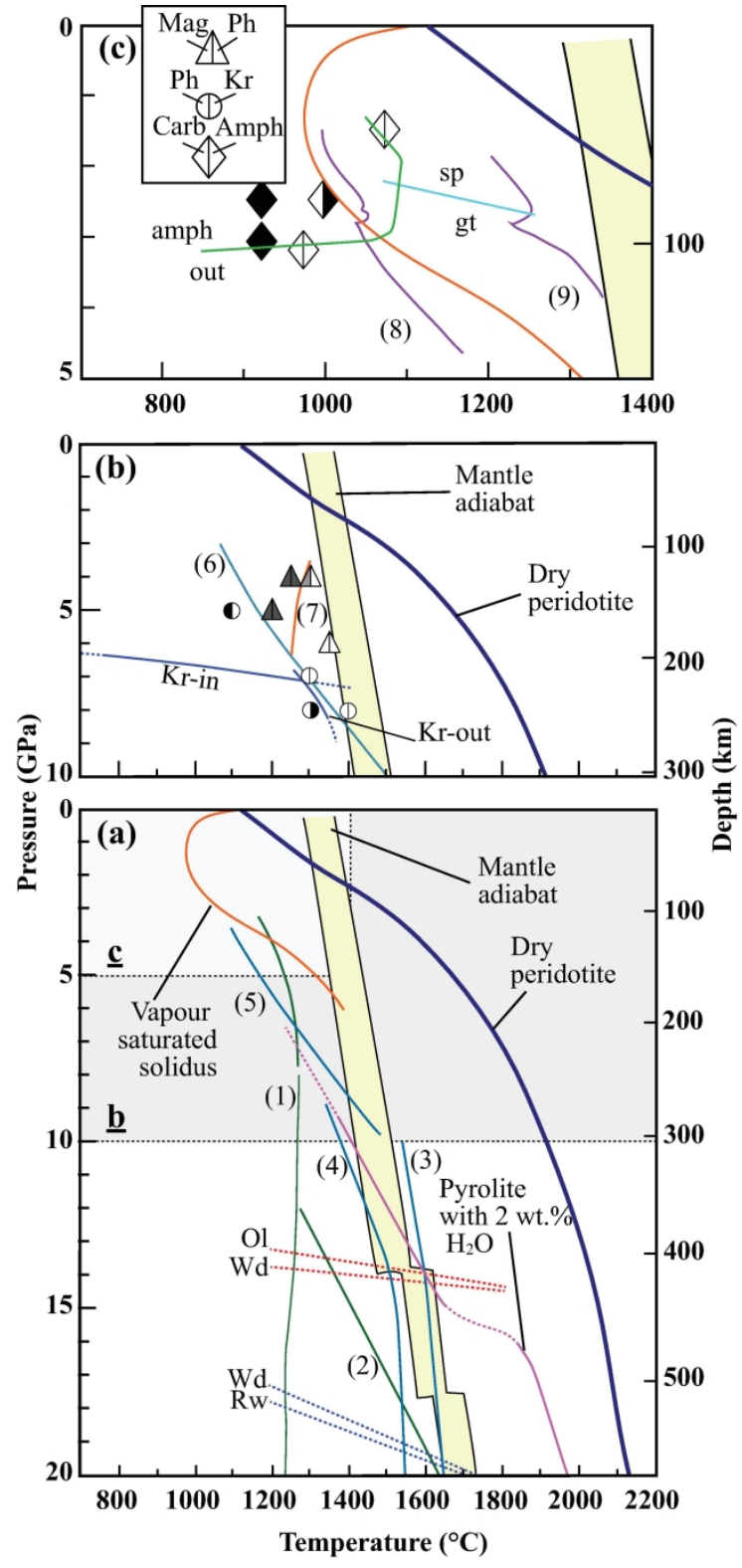

FIG. 8: Pressure-temperature diagram illustrating a) the solidus of different mantle components resulting from melting experiments, including mantle adiabatic temperature (after Katsura et al., 2010), (b) and (c) phase relationships of hydrated/carbonated phases in the upper mantle. Solid and dashed lines colour code: dark blue, solidus of dry peridotite from Herzberg et al. (2000); pink, solidus of pyrolite (2 wt\% H2O after Litasov \& Ohtani, 2002) and orange, solidus of vapour saturated peridotite (Green, 2015). Dashed red and blue lines (Fig. a) show the Wadsleyite (Wd) and Ringwoodite (Rw)- out boundaries, respectively. Solid blue and green lines (Figs. b and c) show K-richterite ( $\mathrm{Kr}$ ) and Ca-amphibole (amph)- out boundaries (Konzett et al. 1997 and Green, 2015). Numbers correspond to (1) solidus of carbonated eclogite (with 4.4 wt\% CO2) (Ghosh et al., 2014), (2) solidus of carbonated eclogite (Keshav \& Gudfinnson, 2010), (3) solidus of fertile peridotite (with 5wt.\% CO2) (Rohrbach \& Schmidt, 2011), (4) Solidus of alkali-rich peridotite (with 5 wt. \% CO2, (5) (Ghosh et al., 2009), (6) solidus of carbonate-bearing fertile peridotite (Dasgupta \& Hirschmann, 2006), (7) solidus of phlogopite-bearing carbonated peridotite (Enggist et al., 2012), (8) solidus of kimberlite and (9) MARID xenoliths (Eggler, 1989). Phase relation of K-richterite with phlogopite obtained from Konzett et al. (1997), phlogopite with magnesite from Enggist et al. (2012), Ca-amphibole and 
carbonated from Green, 2015. Dark quadrant means that the corresponding phase is present. Abbreviations are: Kr, K-richterite; $\mathrm{Ph}$, phlogopite; Amph; Ca-amphibole; Mag; magnesite and Carb; Carbonate.

$203 \times 436 \mathrm{~mm}(300 \times 300$ DPI $)$ 


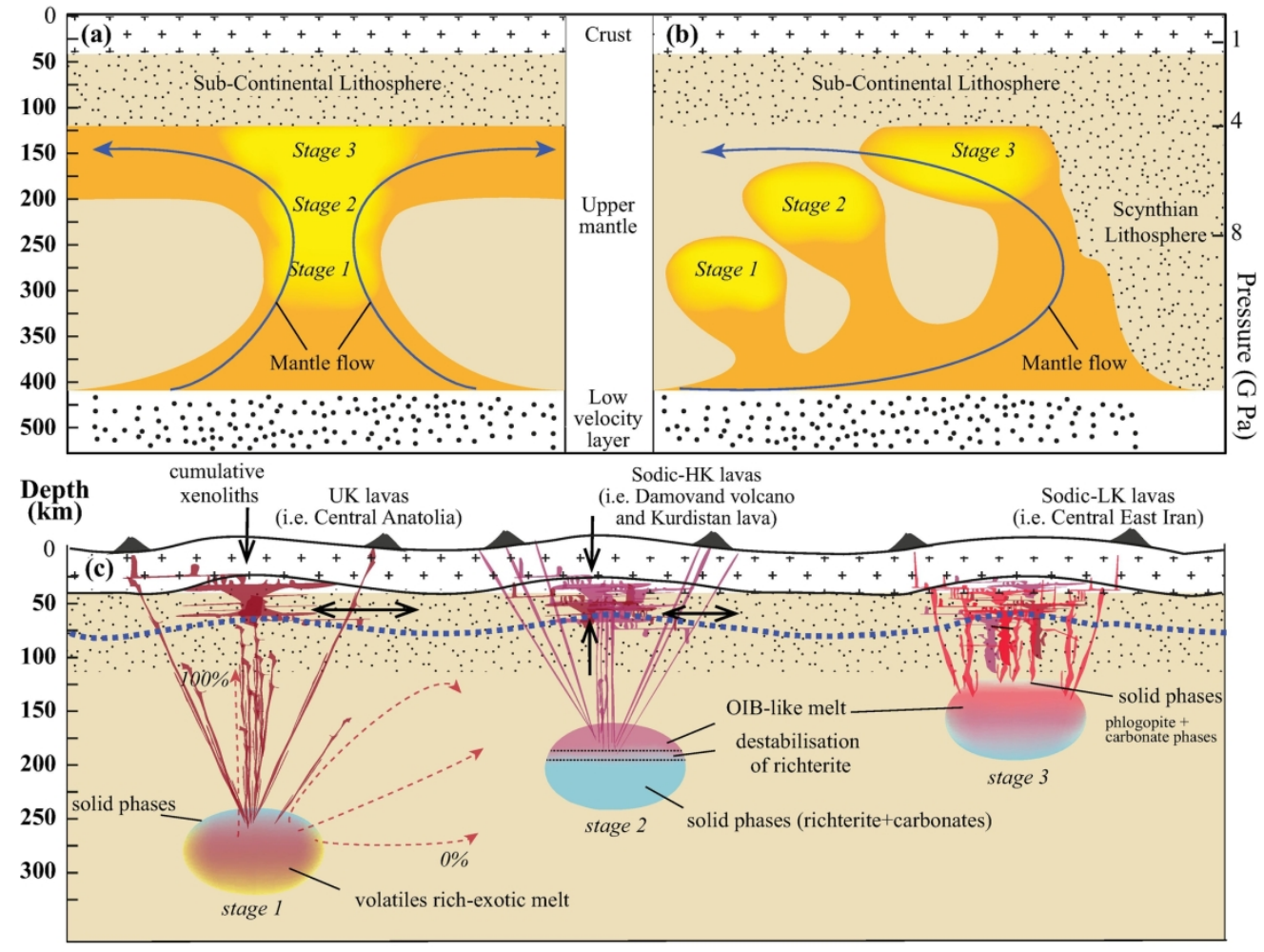

FIG. 9 : ( $a$ and $b$ ) Sketches proposed for the development and ascent of CPs from the low velocity layer at the top of the MTZ towards the surface. In case a, the upper mantle is motionless; in case b, the low velocity layer and the overlying mantle move north with the BMW. In the first case, synchronous sets of diapirs develop of width $\sim 100 \mathrm{~km}$, whereas in the b) case, the northern diapirs develop before the southern ones. At 240 depth ( $8 \mathrm{GPa}$ ), the group of diapirs form a CP, in relation to the crystallization of interstitial volatile-rich melt of hydrated-carbonated phases (stage 1$)$. When this CP rises at $195 \mathrm{~km}$ depth $(6.5 \mathrm{GPa}$, stage 2), hydrated-carbonated phases destabilise. Finally at depths shallower than $150 \mathrm{~km}$ (stage 3), hydrous melting occurs. During stage 1, 2 and 3 the accumulation of melt inside the CPs leads to a drastic increase of the effective pressure at their top, hydro-fracturation of the surrounding mantle and the generation of dyke swarms. It is deduced that during stage 1 , the melt extracted from the CPs has a rcomposition similar to UK-lavas; such melt may form cumulates at shallower depths (Fig. c, stage 1). During the second stage, the extracted melt is similar to OIB-like melt (sodic-HK lavas). Finally, during stage 3, melting of fertile peridotite leads to OIB-like melt (sodic-LK lavas). 

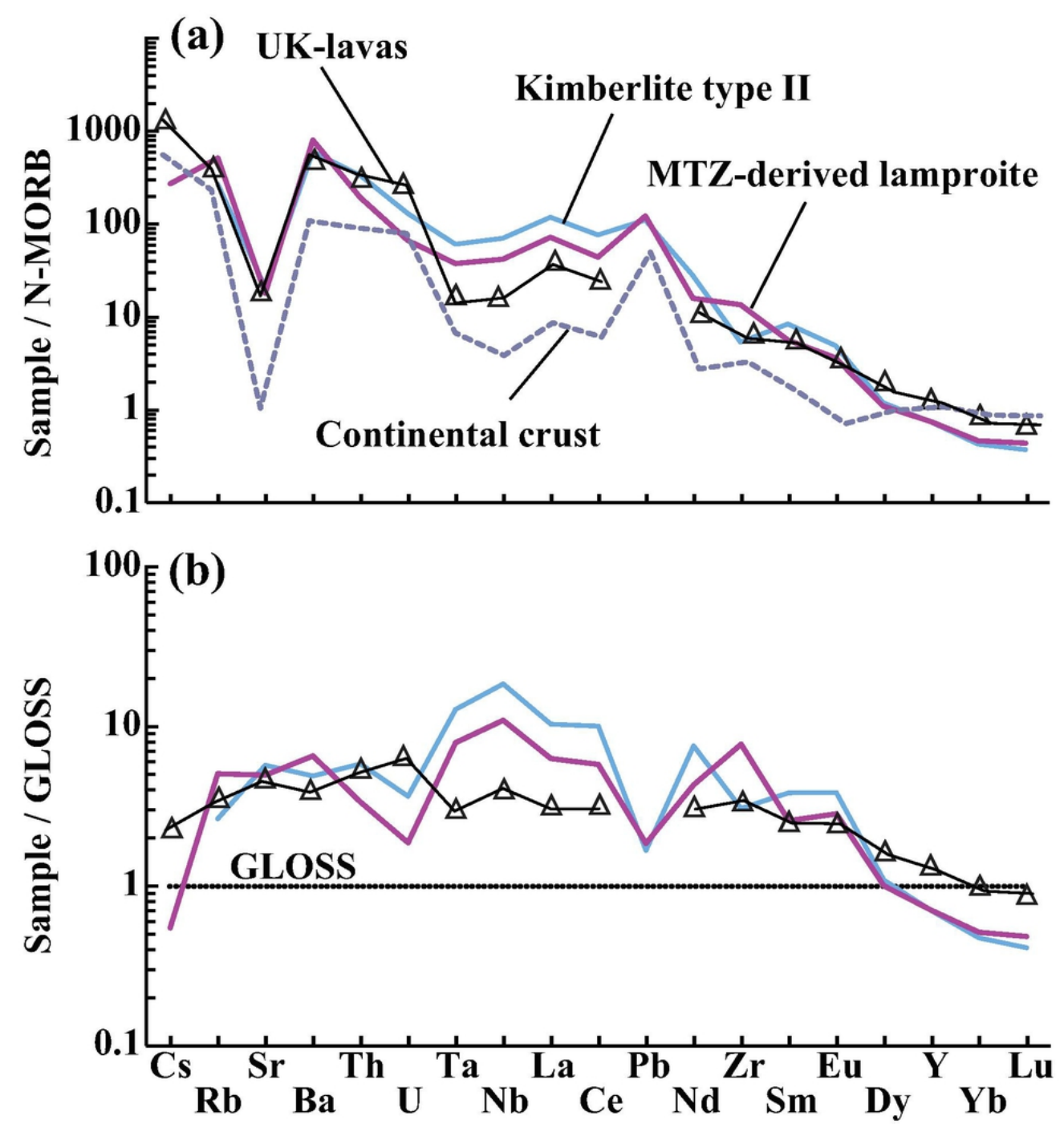

FIG. 10: a) N-MORB normalized (Sun \& McDonough, 1989) and (b) GLOSS normalized (Plank \& Langmuir, 1998) trace element concentration of the most primitive UK- lava (taken from Aghazadeh et al., 2015). Comparison with the average kimberlite type II (Becker \& Le Roex, 2006), the MTZ-derived lamproite (Murphy et al., 2002) and the continental crust of NW Iran (Shahzeid et al., 2017). 

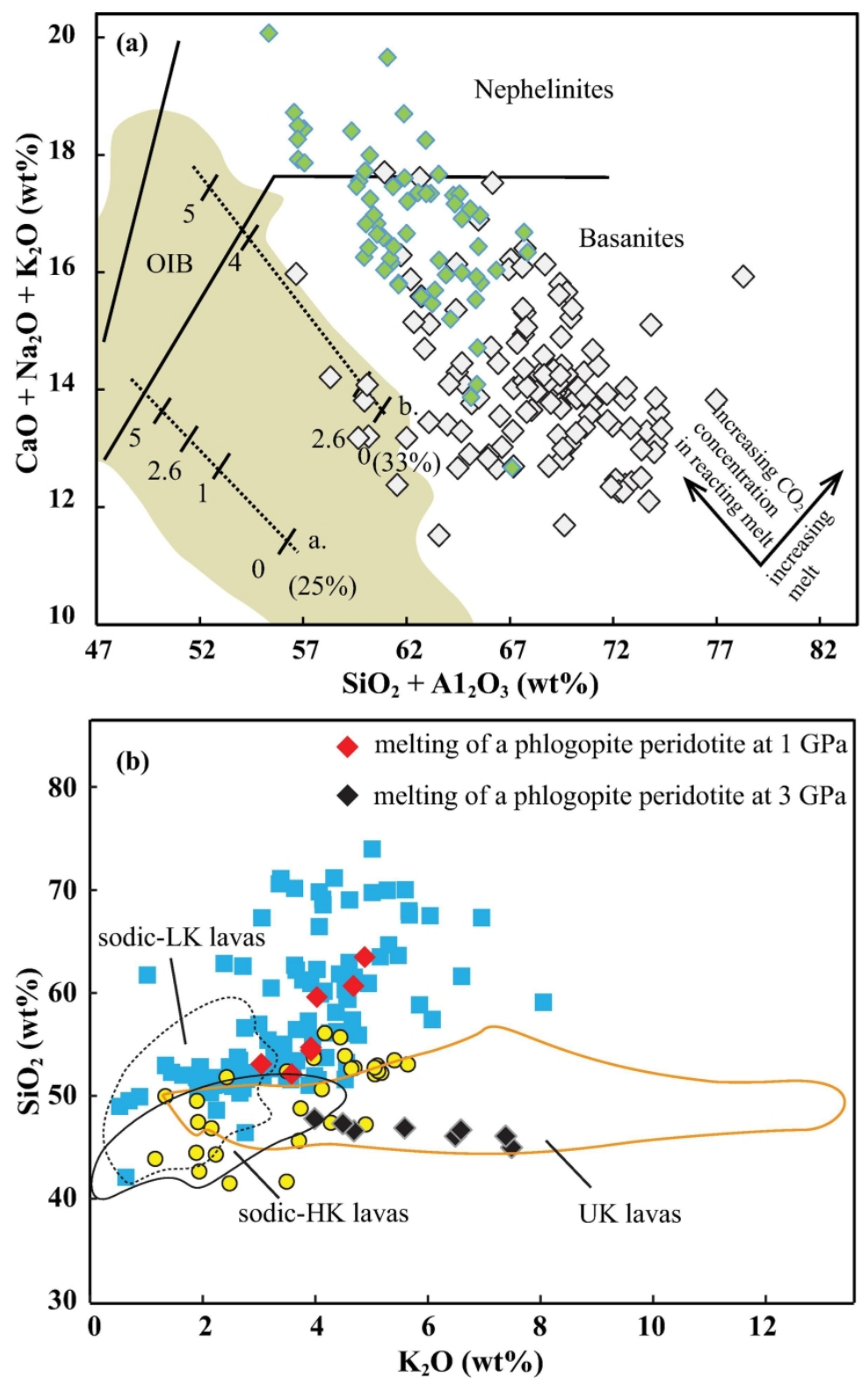

FIG. 11 : (a) $\mathrm{CaO}+\mathrm{Na} 2 \mathrm{O}+\mathrm{K} 2 \mathrm{O}$ (wt \%) versus $\mathrm{SiO} 2+\mathrm{Al} 2 \mathrm{O} 3$ (wt\%) diagram illustrating the effect of variable $\mathrm{CO} 2$ on hybrid peridotite derived-melt at $3 \mathrm{GPa}$ and on alkali and silica content of primary melts. When the $\mathrm{CO} 2$ content of the melt reacting with the mantle increases, the silica under-saturation and/or the alkalinity of the resulting melts after reaction also increase. OIB field, trajectory of arrows and number next to them obtained from Mallik \& Dasgupta, 2014. (b) SiO2 vs K2O diagram showing the composition of old potassic plutonic rocks (blue square) and TK lavas (yellow circle). This diagram illustrates that melt resulting from melting of phlogopite-bearing mantle at 1 (Condamine \& Médard, 2014) and 3 GPa (Condamine et al., 2016) cannot explain the high $\mathrm{K} 2 \mathrm{O}$ contents in UK-lavas ( $12 \mathrm{wt} \%)$, but may explain the K2O content of plutonic rocks at $1 \mathrm{GPa}$. 

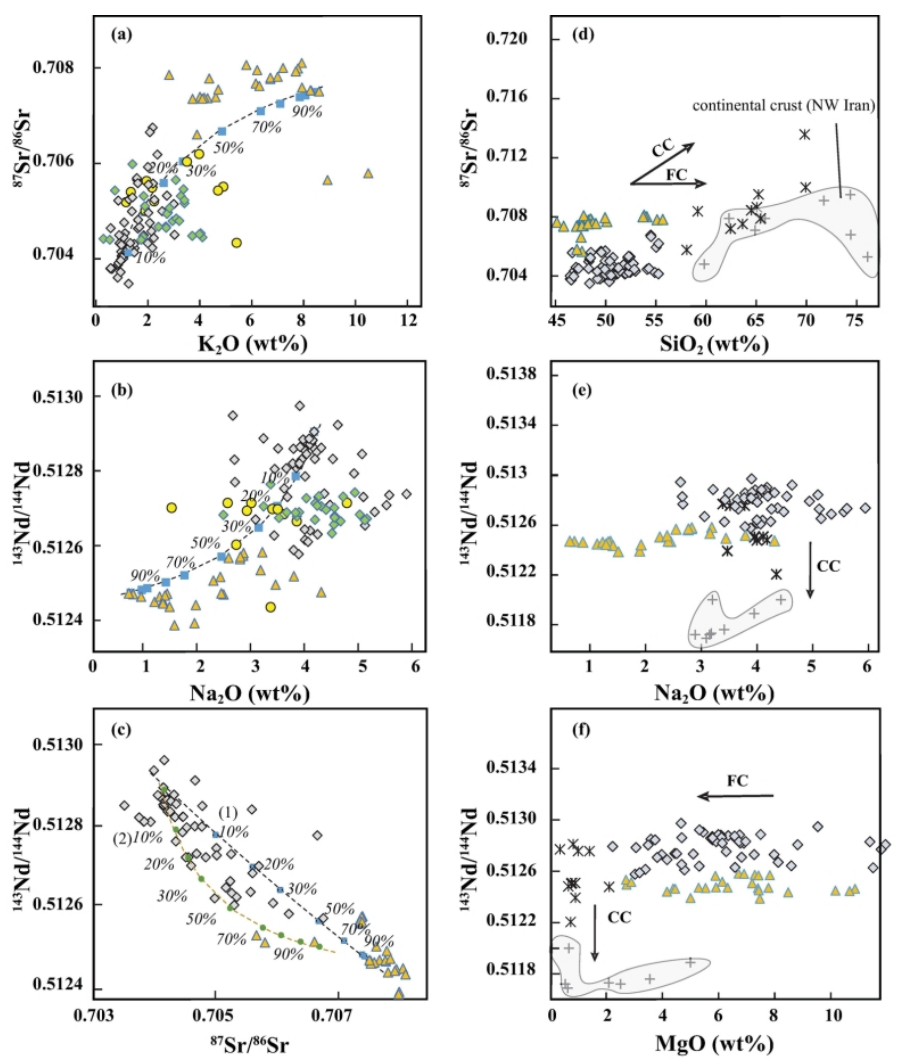

FIG. 12: Sr-Nd isotope ratios vs major elements (K2O wt\%, Na2O wt\%, MgO wt\% and SiO2 wt\%) illustrating effect of mixing (a-c) fractional crystallization (FC) and crustal contamination (CC). (d-f) for alkaline magmatism in the TIP. In figures $a-c$, the black and orange dashed lines are mixing lines between the most primitive sodic-LK lavas and UK lavas (1) and cumulative xenoliths (2), respectively. The numbers on the lines specify the mixing rate between two compositions. Figures e-f illustrat that the composition of A-type granitoids (black starts) may result from FC of alkaline lavas (e.g. sodic-LK lavas) affected by CC. In addition, isotopic heterogeneity for UK and sodic-LK lavas evidences that FC alone cannot explain their compositional diversities. Continental crust field from the TIP based on data from Shahzeidi et al. (2017). Symbols are similar to figures 2 .

$195 \times 156 \mathrm{~mm}(300 \times 300 \mathrm{DPI})$ 


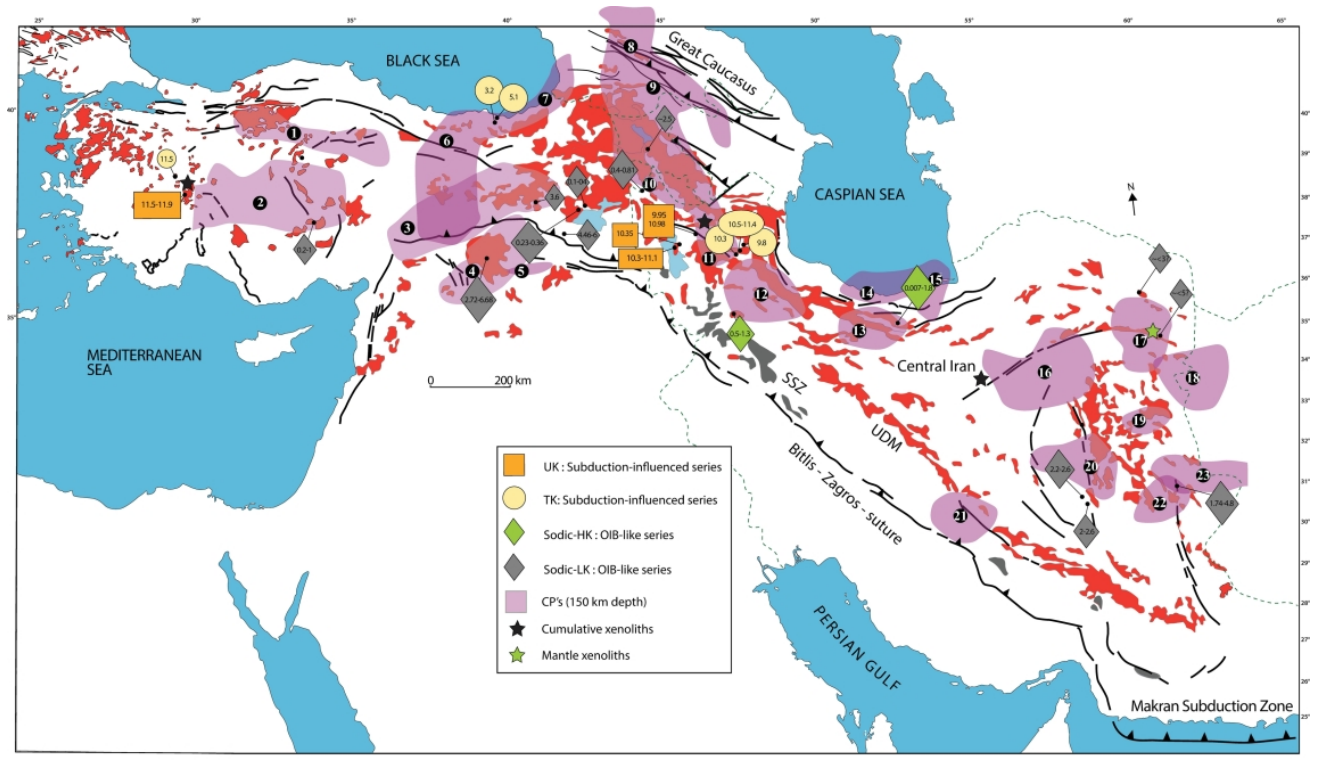

FIG. 13a: Geological schematic map of the TIP showing the age distribution and composition of (a) young volcanic rocks $(<11 \mathrm{Ma})$

$293 \times 170 \mathrm{~mm}(300 \times 300 \mathrm{DPI})$ 


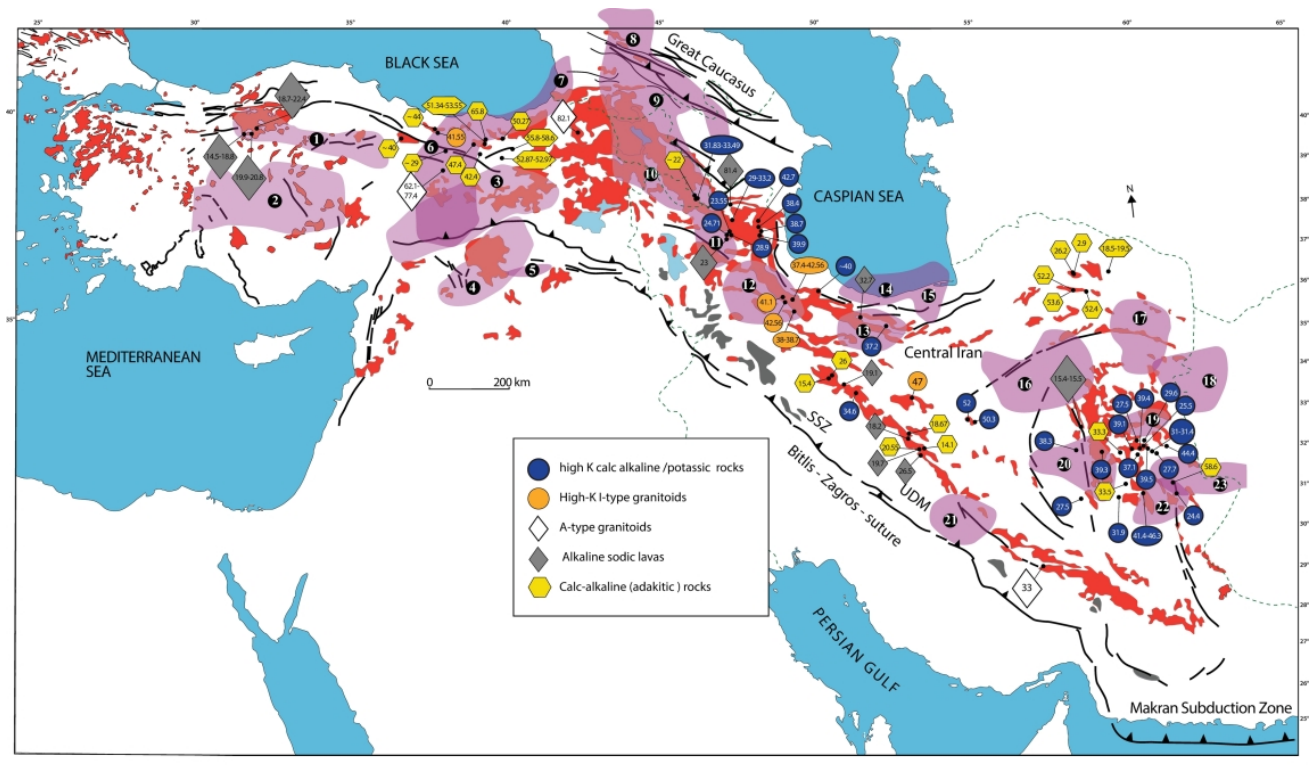

FIG. 13b: (b) volcanic and plutonic rocks from $11 \mathrm{Ma}$ to $\sim 80 \mathrm{Ma}$ (age references included in supplementary material, table 2 appendix). Pink area show distribution of CPs at $150 \mathrm{~km}$ depth (adapted from figure 5 and $6)$.

$297 \times 174 \mathrm{~mm}(300 \times 300$ DPI) 

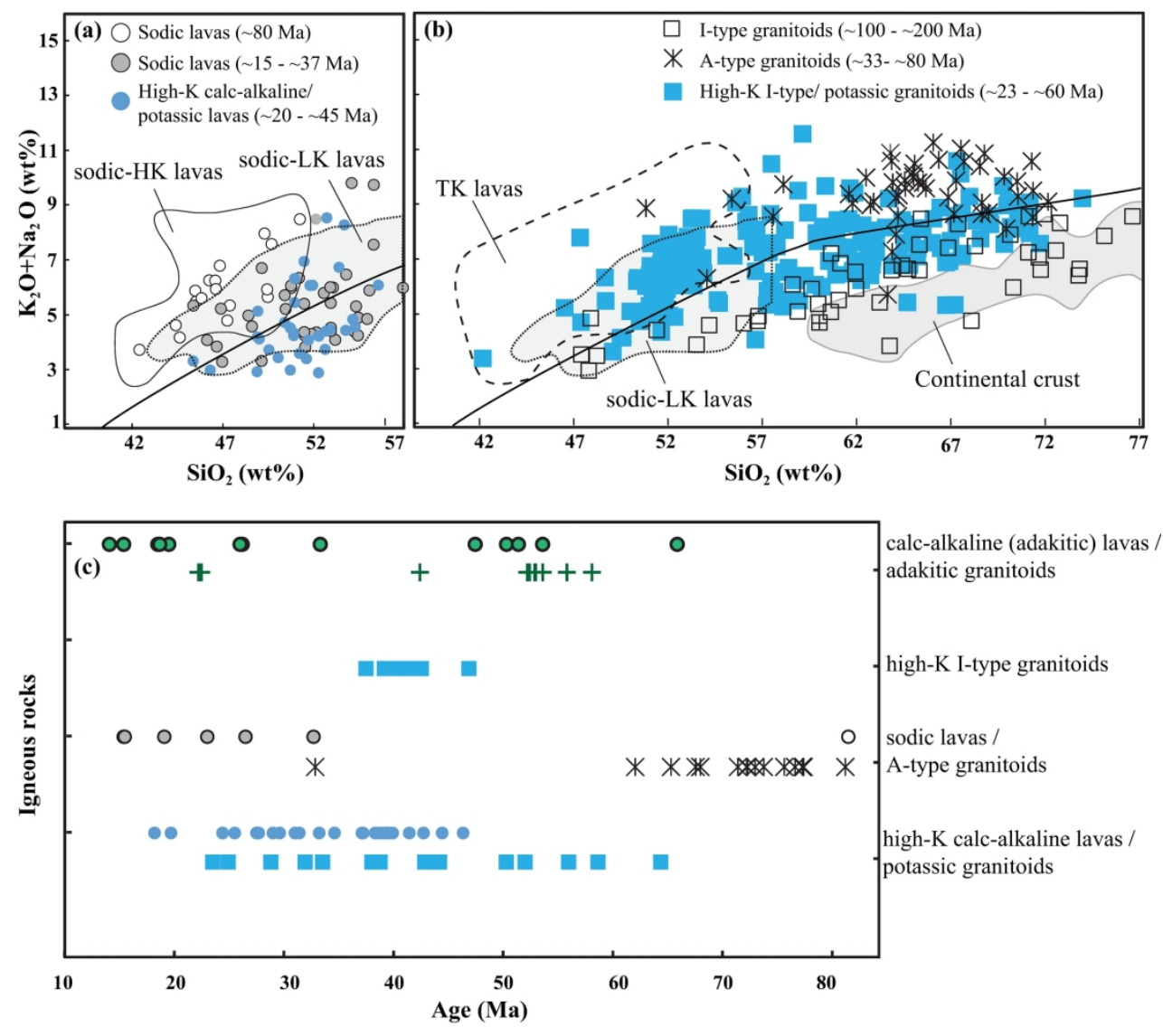

FIG. 14: a) Total alkali vs. silica diagram (TAS; Le Bas et al., 1986) for (a) volcanic and (b) plutonic rocks from 11 to $\sim 80 \mathrm{Ma}$ in the TIP. TK, sodic HK-and- LK young lavas field reported for comparison. The solid bold line highlights the transition between alkaline and subalkaline magmatic series (after Irvine \& Baragar, 1971).c) Diagram relating volcanic and plutonic magmatic ages and relative compositions throughout the TIP (references for age and composition listed in table 2 appendix) with time (in Ma).

$210 \times 188 \mathrm{~mm}(300 \times 300 \mathrm{DPI})$ 